\title{
Hydrogeology and Simulated Effects of Ground-Water Withdrawals, Kirkwood- Cohansey Aquifer System, Upper Maurice River Basin Area, New Jersey
}

By Stephen J. Cauller and Glen B. Carleton

Prepared in cooperation with the

NEW JERSEY DEPARTMENT OF ENVIRONMENTAL PROTECTION

Scientific Investigations Report 2005-5258 


\section{U.S. Department of the Interior \\ Gale A. Norton, Secretary}

\section{U.S. Geological Survey \\ P. Patrick Leahy, Acting Director}

\section{U.S. Geological Survey, Reston, Virginia: 2006}

For product and ordering information:

World Wide Web: http://www.usgs.gov/pubprod

Telephone: 1-888-ASK-USGS

For more information on the USGS--the Federal source for science about the Earth, its natural and living resources, natural hazards, and the environment:

World Wide Web: http://www.usgs.gov

Telephone: 1-888-ASK-USGS

Any use of trade, product, or firm names is for descriptive purposes only and does not imply endorsement by the U.S. Government.

Although this report is in the public domain, permission must be secured from the individual copyright owners to reproduce any copyrighted materials contained within this report. 


\section{Contents}

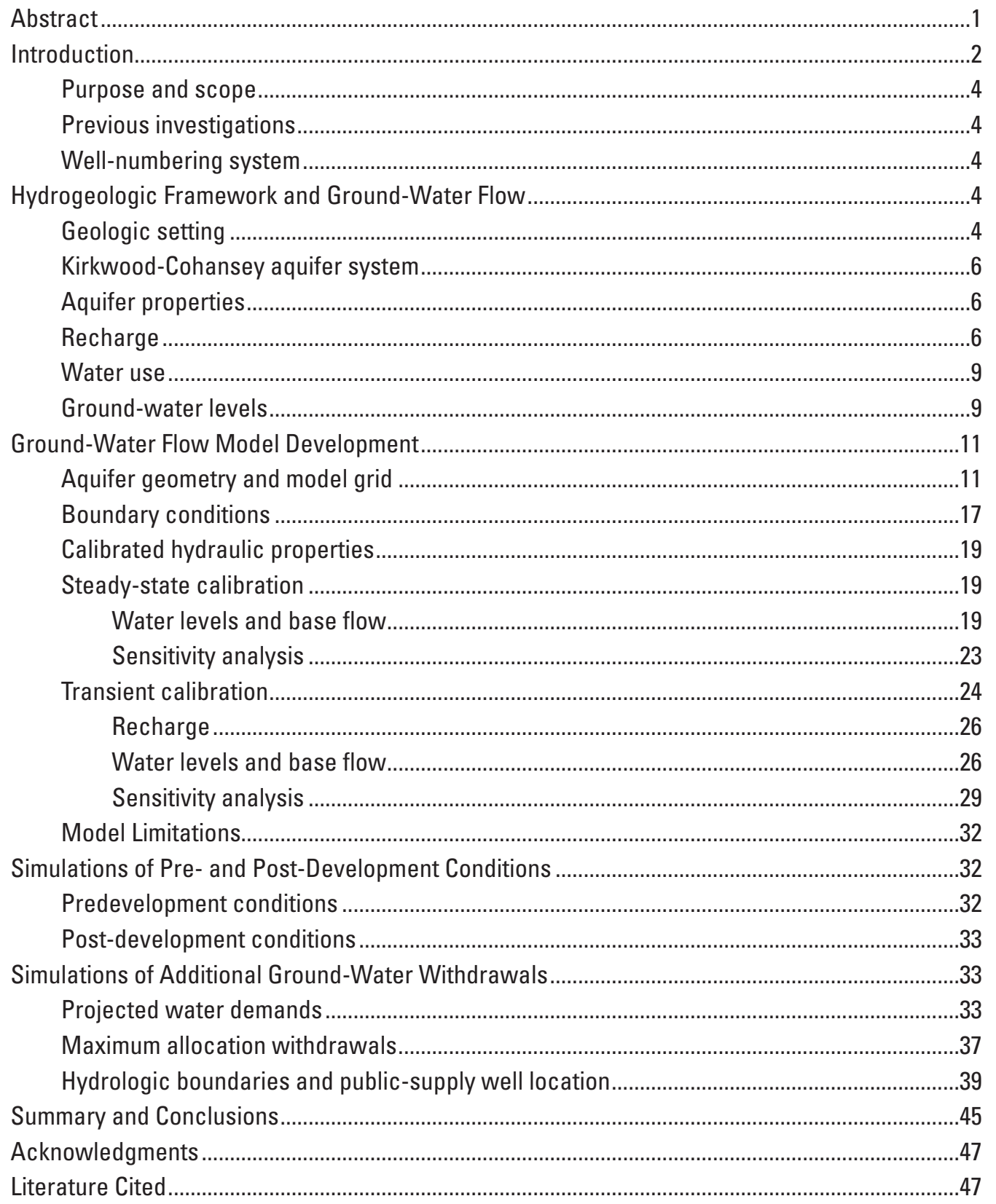




\section{Figures}

1-3. Maps showing-

1. Location of study area and Maurice River Basin in New Jersey.. .2

2. Location of townships, upper Maurice River Basin area, N.J ...................................3

3. Location of surface-water basins, upper Maurice River Basin area, N.J .................5

4. Generalized stratigraphic section through the Kirkwood-Cohansey aquifer system, upper Maurice River Basin area, N.J.

5-6. Maps showing-

5. Thickness of the Kirkwood-Cohansey aquifer system, upper Maurice River Basin area, N.J... .8

6. Location of wells screened in the Kirkwood-Cohansey aquifer system with reported mean annual withdrawals during 1990-96.

7. Graph showing reported annual ground-water withdrawals by water allocation permit series upper Maurice River Basin area, N.J., 1990-96.

8-9. Maps showing-

8. Composite water-table of the Kirkwood-Cohansey aquifer system, upper Maurice River Basin area, N.J

9. Location of observation wells, upper Maurice River Basin area, N.J. .13

10. Graph showing water-level hydrographs for selected wells in the upper Maurice River Basin area, N.J., during 1995-97

11. Diagrammatic section of (a) lithology, and (b) ground-water flow model layers in the upper Maurice River Basin area, N.J.

12. Variably-spaced model grid, lateral boundaries, and stream cells, upper Maurice River Basin area, N.J

13-14. Maps showing-

13. Location of streamflow-gaging stations, upper Maurice River Basin area, N.J

14. Composite measured and simulated 1990-95 water-table altitudes, upper Maurice River Basin area, N.J....

15-21. Graphs showing-

15. Estimated and simulated mean annual base flow at 24 streamflow-gaging stations, upper Maurice River Basin area, N.J., 1990-95.

16. Sensitivity of (a) simulated water-level altitudes, and (b) and (c) simulated base flow, to variations in the values of ground-water withdrawals and hydrologic properties, upper Maurice River Basin area, N.J

17. Daily precipitation recorded at Glassboro, N.J., weather station and waterlevel altitudes in well 15-1054, November 8, 1994 to February 28, 1995

18. Monthly precipitation recorded at Glassboro, N.J., weather station and estimated monthly recharge, January 1994 through March 1997

19. Measured and simulated monthly water-level altitudes at selected observation wells in the upper Maurice River Basin area, N.J., January 1995 through March 1997

20. Estimated and simulated monthly base flow at streamflow-gaging stations (a) Scotland Run near Williamstown, N.J. (014111460); (b) Scotland Run at Franklinville, N.J. (01411462); and (c) Maurice River at Norma, N.J. (01411500), January 1994 through March 1997. 
21. Relation of (a) simulated water-level altitudes and (b) simulated base flow to variations in the values of hydrologic properties during October 1994 and March 1997, upper Maurice River Basin area, N.J.

22. Map showing vertical flow direction between model layers 1 and 2 during steadystate predevelopment conditions, upper Maurice River Basin area, N.J.

23-24. Graphs showing-

23. Simulated base-flow reduction in the upper Maurice River Basin area at streamflow-gaging stations Scotland Run near Williamstown, N.J. (01411460); Scotland Run at Franklinville, N.J. (01411462); Muddy Run at Centerton, N.J. (01411700); and Maurice River near Millville, N.J. (01411800) as a result of post-development ground-water withdrawals.

24. Simulated base flow at streamflow-gaging stations (a) Scotland Run near Williamstown, N.J. (01411460); Scotland Run at Fries Mill, N.J. (01411461); and Scotland Run at Franklinville, N.J. (01411462); and (b) Muddy Run at Centerton, N.J. (0141170); and Maurice River at Norma,N.J. (01411500), during 2009-11 and 2039-41, using estimated ground-water withdrawals

25. Map showing location of all wells with a permitted ground-water withdrawal allocation from the Kirkwood-Cohansey aquifer system (as of 1997), in the upper Maurice River Basin area, N.J

26-28. Graphs showing-

26. Simulated monthly base flow during predevelopment, post-development, and maximum allocation conditions at streamflow-gaging stations (a) Scotland Run near Williamstown, N.J. (01411460); (b) Scotland Run at Fries Mill, N.J. (01411461); and (c) Scotland Run at Franklinville, N.J. (01411462).

27. Simulated monthly base flow during predevelopment, post-development, and maximum allocation conditions at streamflow-gaging stations (a) Muddy Run at Centerton, N.J. (01411700); (b) Maurice River at Norma, N.J. (01411500); and (c) Maurice River near Millville, N.J. (01411800)

28. Simulated base-flow reduction in the upper Maurice River Basin area at streamflow-gaging stations Scotland Run near Williamstown, N.J. (01411460); Scotland Run at Franklinville, N.J. (01411462); Muddy Run at Centerton, N.J. (01411700); Maurice River at Norma, N.J. (01411500); and Maurice River near Millville, N.J. (01411800), due to maximum allocation ground-water withdrawals

29-30. Maps showing-

29. Location of stream cells with decrease of greater than 0.5 cubic feet per second in base flow or conversion from a gaining to losing cell resulting from maximum allocation ground-water withdrawals, in the upper Maurice River Basin area, N.J

30. Location of three hypothetical public-supply wells in Monroe Township, Gloucester County located adjacent to Scotland Run (simulation 1), and on the surface-water divide between Little Ease Run and Scotland Run (simulation 2)

31. Graph showing simulated base flow at streamflow-gaging stations (a) Scotland Run near Williamstown, N.J. (01411460), and (b) Little Ease Run near Clayton, N.J. (01411456), using withdrawals from three hypothetical public-supply wells located near the stream or on a surface-water divide. 


\section{Tables}

1. Stratigraphy and hydrogeologic units, upper Maurice River Basin area, N.J.................7

2. Ground-water allocation permit series.........................................................................

3. Well construction data and range of water levels from January 1995 through March 1997.

4. Hydrologic properties used in the simulation of ground-water flow, upper Maurice River Basin area, N.J.

5. Simulated water levels (1990-95) and average measured water levels (1995-97) at 46 monitoring wells, upper Maurice River Basin area, N.J.............................................21

6. Simulated and estimated mean annual base flow at 24 streamflow-gaging stations during 1990-95, upper Maurice River Basin area, N.J.

7. Simulated and measured water-level fluctuations at eight observation wells during 1995-97, upper Maurice River Basin area, N.J.

8. Simulated and estimated mean monthly base flow at Maurice River streamflow-gaging stations, N.J., for January 1995-March 1997

9. Reported 1995, and projected 2010 and 2040 ground-water withdrawals, upper Maurice River Basin area, N.J.

10. Reported and maximum allocation ground-water withdrawals, upper Maurice River Basin area, N.J., 1995 


\section{Conversion Factors and Vertical Datum}

\begin{tabular}{|c|c|c|}
\hline Multiply & By & To obtain \\
\hline \multicolumn{3}{|c|}{ Length } \\
\hline inch (in.) & 2.54 & centimeter $(\mathrm{cm})$ \\
\hline inch (in.) & 25.4 & millimeter (mm) \\
\hline foot $(\mathrm{ft})$ & 0.3048 & $\operatorname{meter}(\mathrm{m})$ \\
\hline mile (mi) & 1.609 & kilometer $(\mathrm{km})$ \\
\hline \multicolumn{3}{|c|}{ Area } \\
\hline square foot $\left(\mathrm{ft}^{2}\right)$ & 929.0 & square centimeter $\left(\mathrm{cm}^{2}\right)$ \\
\hline square foot $\left(\mathrm{ft}^{2}\right)$ & 0.09290 & square meter $\left(\mathrm{m}^{2}\right)$ \\
\hline square inch $\left(\mathrm{in}^{2}\right)$ & 6.452 & square centimeter $\left(\mathrm{cm}^{2}\right)$ \\
\hline square mile $\left(\mathrm{mi}^{2}\right)$ & 2.590 & square kilometer $\left(\mathrm{km}^{2}\right)$ \\
\hline \multicolumn{3}{|c|}{ Volume } \\
\hline gallon (gal) & 3.785 & liter $(\mathrm{L})$ \\
\hline gallon (gal) & 0.003785 & cubic meter $\left(\mathrm{m}^{3}\right)$ \\
\hline million gallons (Mgal) & 3,785 & cubic meter $\left(\mathrm{m}^{3}\right)$ \\
\hline cubic foot $\left(\mathrm{ft}^{3}\right)$ & 28.32 & cubic decimeter $\left(\mathrm{dm}^{3}\right)$ \\
\hline cubic foot $\left(\mathrm{ft}^{3}\right)$ & 0.02832 & cubic meter $\left(\mathrm{m}^{3}\right)$ \\
\hline \multicolumn{3}{|c|}{ Flow rate } \\
\hline cubic foot per second $\left(\mathrm{ft}^{3} / \mathrm{s}\right)$ & 0.02832 & cubic meter per second $\left(\mathrm{m}^{3} / \mathrm{s}\right)$ \\
\hline gallon per minute (gal/min) & 0.06309 & liter per second $(\mathrm{L} / \mathrm{s})$ \\
\hline gallon per day $(\mathrm{gal} / \mathrm{d})$ & 0.003785 & cubic meter per day $\left(\mathrm{m}^{3} / \mathrm{d}\right)$ \\
\hline million gallons per day $(\mathrm{Mgal} / \mathrm{d})$ & 0.04381 & cubic meter per second $\left(\mathrm{m}^{3} / \mathrm{s}\right)$ \\
\hline \multicolumn{3}{|c|}{ Specific capacity } \\
\hline $\begin{array}{l}\text { gallon per minute per foot } \\
[(\mathrm{gal} / \mathrm{min}) / \mathrm{ft})]\end{array}$ & 0.2070 & liter per second per meter $[(\mathrm{L} / \mathrm{s}) / \mathrm{m}]$ \\
\hline \multicolumn{3}{|c|}{ Hydraulic conductivity } \\
\hline foot per day (ft/d) & 0.3048 & meter per day $(\mathrm{m} / \mathrm{d})$ \\
\hline \multicolumn{3}{|c|}{ Hydraulic gradient } \\
\hline foot per mile $(\mathrm{ft} / \mathrm{mi})$ & 0.1894 & meter per kilometer $(\mathrm{m} / \mathrm{km})$ \\
\hline \multicolumn{3}{|c|}{ Transmissivity* } \\
\hline foot squared per day $\left(\mathrm{ft}^{2} / \mathrm{d}\right)$ & 0.09290 & meter squared per day $\left(\mathrm{m}^{2} / \mathrm{d}\right)$ \\
\hline
\end{tabular}

Vertical coordinate information is referenced to the National Geodetic Vertical Datum of 1929 (NGVD29).

Horizontal coordinate information is referenced to the North American Datum of 1983 (NAD 83).

Altitude, as used in this report, refers to distance above or below NGVD29.

*Transmissivity: The standard unit for transmissivity is cubic foot per day per square foot times foot of aquifer thickness $\left[\left(\mathrm{ft}^{3} / \mathrm{d}\right) / \mathrm{ft}^{2}\right] \mathrm{ft}$. In this report, the mathematically reduced form, foot squared per day $\left(\mathrm{ft}^{2} / \mathrm{d}\right)$, is used for convenience. 


\title{
Hydrogeology and Simulated Effects of Ground-Water Withdrawals, Kirkwood-Cohansey Aquifer System, Upper Maurice River Basin Area, New Jersey
}

\author{
By Stephen J. Cauller and Glen B. Carleton
}

\section{Abstract}

The unconfined Kirkwood-Cohansey aquifer system in the upper part of the Maurice River Basin, N.J., provides fresh ground water for a variety of uses. The study area encompasses eastern Gloucester and Salem Counties, northern Cumberland County, and western Atlantic County. Threedimensional steady-state and transient models of the Kirkwood-Cohansey aquifer system were developed to simulate ground-water flow in the study area for predevelopment conditions, post-development conditions, and future conditions based on ground-water withdrawal alternatives.

A comparison of predevelopment conditions with postdevelopment (1995-97) conditions using a transient simulation reveals considerable base-flow reduction in the headwaters area of Scotland Run as a result of withdrawals from nearby public-supply wells, especially during months of low recharge. Results of simulations indicate base-flow reduction was nearly 62 percent at Scotland Run near Williamstown, N.J. (01411460), in August 1995. Agricultural withdrawals in the Muddy Run Basin affected base flow at Muddy Run at Centerton, N.J. (01411700), reducing base flow by 38 percent during August 1995. Base-flow reduction near the southern boundary of the flow model, corresponding to the location of the streamflow-gaging station Maurice River at Norma, N.J. (01411500), was due to the combined effect of public-supply, commercial, industrial, agricultural, and low-volume institutional ground-water withdrawals in the Maurice River Basin. Base flow in the Maurice River at Norma, N.J. (01411500), decreased by nearly 26 percent during August 1995, between predevelopment and post-development conditions. Base flow was reduced by a comparable quantity at the same streamflowgaging stations during September 1996, even though higher recharge rates lead to higher base-flow values at this time of year.

The future conditions scenario used projections of ground-water demand by municipality for 1995-2040 to simulate the effects of potential ground-water withdrawals in 2010-11 and 2040-41. Hydrologic conditions for 2010 and 2040 were simulated with below-average recharge and for years 2011 and 2041 with above-average recharge. Results indicate that base flow would cease at Scotland Run near Wil- liamstown (01411460) and would decline to 4.32 cubic feet per second $\left(\mathrm{ft}^{3} / \mathrm{s}\right)$ at Muddy Run at Centerton, N.J. (01411700), and $28.48 \mathrm{ft}^{3} / \mathrm{s}$ at Maurice River at Norma, N.J. (01411500), during August 2010. Similar base-flow values were projected for 2040. Simulated base flow ceased at Scotland Run near Williamstown, N.J. (01411460); was $4.09 \mathrm{ft}^{3} / \mathrm{s}$ at Muddy Run at Centerton, N.J. (01411700); and $25.14 \mathrm{ft}^{3} / \mathrm{s}$ at Maurice River at Norma, N.J. (01411500), during August 2011. Simulated base flow during 2011 and 2041 rebounded from lows in 2010 and 2040, respectively, because conditions were simulated with higher recharge rates than those used in the preceding year.

A scenario representing maximum allocation groundwater withdrawal conditions was simulated using all wells in the study area that had been issued a water allocation permit by 1997 . Ground-water withdrawal rates from each well were set to the maximum monthly and annual rates specified by the permit. Results of this simulation indicated considerable reductions in base flow in the Maurice River, particularly during periods of low recharge. When climatic conditions that occurred during 1994-97 were used, results indicated that during a dry year like 1995, simulated base flow would stop at Scotland Run near Williamstown, N.J. (01411460) from June through September. Simulated base flow at Scotland Run at Franklinville, N.J. (01411462), and at Muddy Run at Centerton, N.J. (01411700), would stop during August 1995. A comparison of maximum allocation conditions with predevelopment conditions indicated a reduction of simulated base flow by 93 percent during August 1995 and by 41 percent during September 1996 at Maurice River at Norma, N.J. (01411500).

Results of a simulation using additional withdrawals from three hypothetical public-supply wells demonstrated that locating the wells in the upper part of the Maurice River Basin affected the magnitude of base-flow reduction. When the wells were located adjacent to Scotland Run there was nearly a oneto-one correspondence between the amount of ground water withdrawn and the amount of base-flow reduction in Scotland Run. When the wells were positioned on a surface-water basin divide between Scotland Run and Little Ease Run, groundwater withdrawals were offset by a reduction in base flow that was distributed between the two streams. 


\section{Introduction}

Southwestern New Jersey experienced considerable growth in population and suburban land development from 1950 to 2000. The combined population of Camden, Gloucester, Salem, Atlantic, and Cumberland Counties increased by 85 percent from 662,974 in 1950 to 1,226,880 in 2000 (Forstall, 1995; U.S. Bureau of the Census, 2001). Ongoing land development in this area has affected the quantity of fresh ground water by decreasing the total acreage of undeveloped land available for natural infiltration of precipitation and recharge to the ground-water flow system. In the southeastern part of Gloucester and Salem Counties, the Kirkwood-Cohansey surficial aquifer system is the primary subsurface source of freshwater where its saturated thickness exceeds 50 feet. Total ground-water withdrawals from the Kirkwood-Cohansey aquifer system have been increasing steadily since the late 1980 s as the number of public-supply wells increased, particularly in the upper part of the Maurice River Basin of southeastern Gloucester and Salem Counties and northern Cumberland County (fig. 1). This area extends from Clementon Borough southeast to Folsom Borough, southwest to the City of Vineland and northwest to Pole Tavern (fig. 2).

Long-term increases in ground-water withdrawals from the Kirkwood-Cohansey aquifer system could affect the entire hydrologic system in several ways. These effects could include a gradual reduction in ground-water levels in parts of the basin, reduction in base flow particularly in headwater areas, reduction in the number and total area of wetlands, migration of ground-water divides, and changes in local flow-system

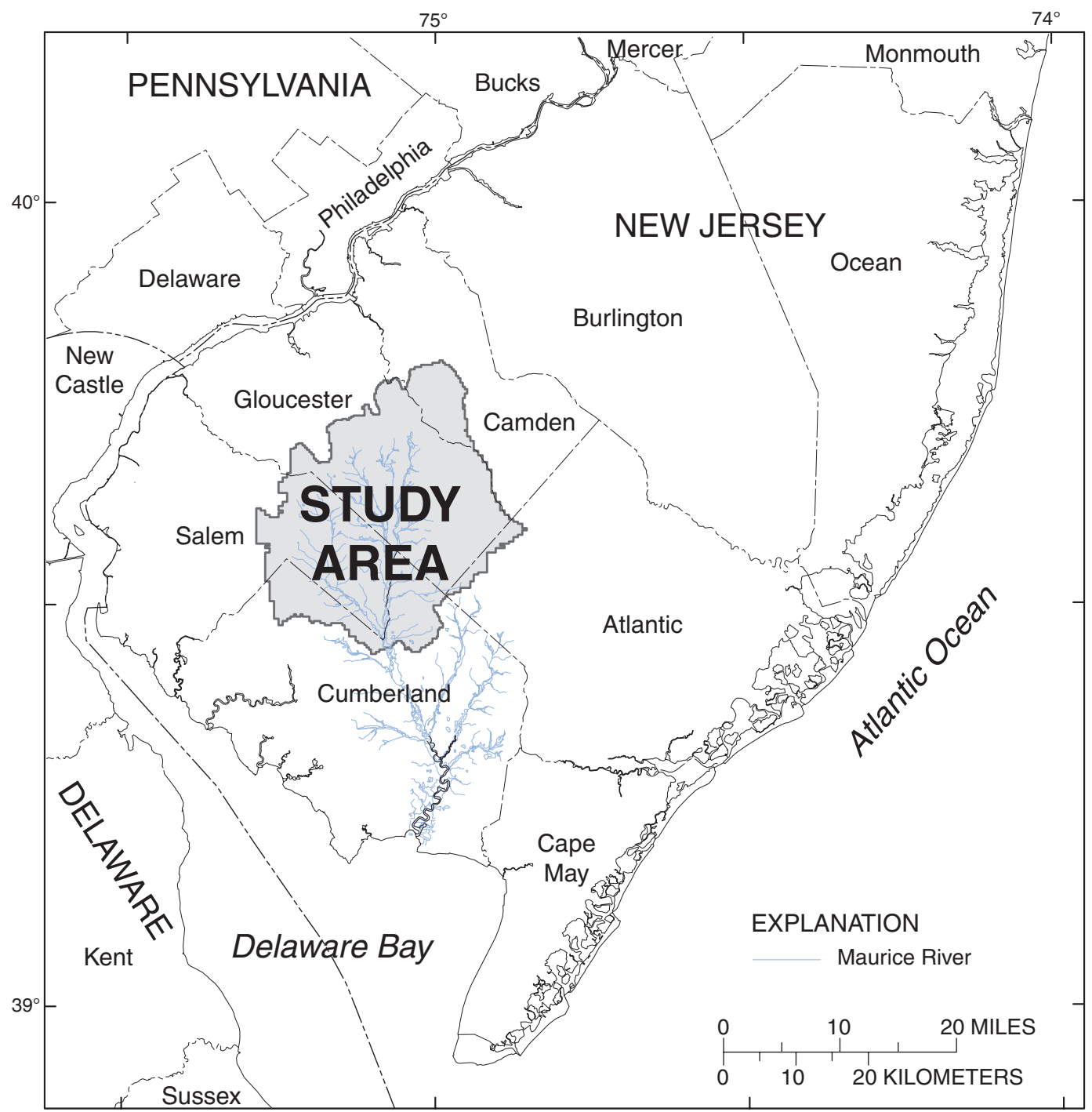

Base from U.S. Geological Survey digital data, 1:100,000, 1983, Universal Transverse Mercator Projection, Zone 18

Figure 1. Location of study area and Maurice River Basin in New Jersey. 


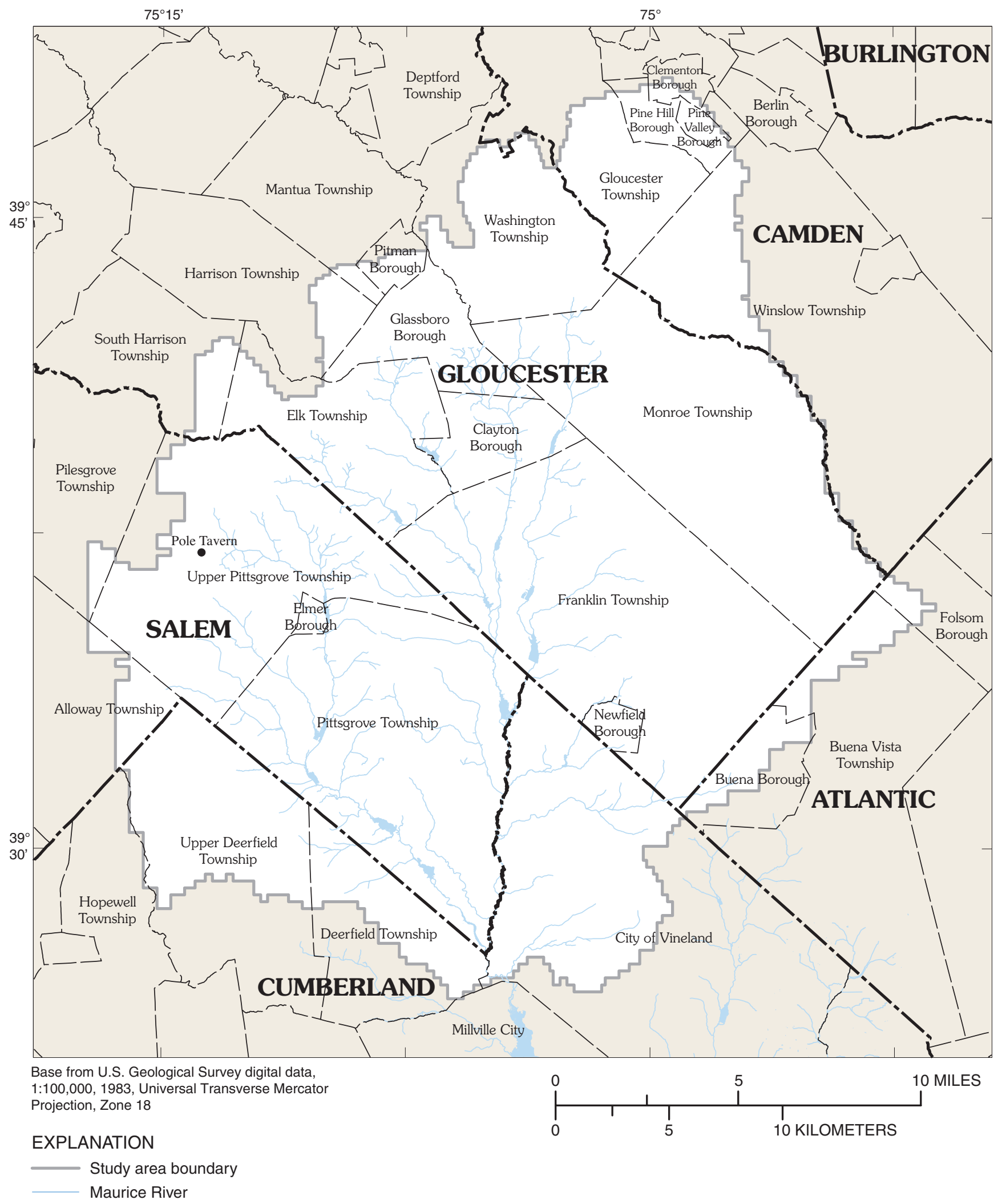

Figure 2. Location of townships, upper Maurice River Basin area, N.J. 
geometries. The U.S. Geological Survey (USGS), in cooperation with the New Jersey Department of Environmental Protection (NJDEP), conducted an investigation to evaluate the potential effects of current (1997) and projected ground-water withdrawals on the unconfined Kirkwood-Cohansey aquifer system in the upper part of the Maurice River Basin (fig. 3).

\section{Purpose and scope}

This report describes the hydrogeologic framework and presents an analysis of ground-water flow in the unconfined Kirkwood-Cohansey aquifer system in the upper Maurice River Basin, including a compilation in tabular and graphical format of the hydrogeologic data used. The report includes descriptions of the steady-state and transient ground-water flow models used to simulate ground-water flow and surfacewater base flow in the upper Maurice River Basin area. The use of the flow model to evaluate the effects of current and future ground-water withdrawals is discussed.

\section{Previous investigations}

Barksdale and others (1958) studied the water resources of southwestern New Jersey, southeastern Pennsylvania, and northern Delaware. In compliance with the 1958 Water Supply Law, a series of reports were written examining the water resources of the counties in New Jersey, including Gloucester County (Hardt and Hilton, 1969), Salem County (Rosenau and others, 1969), and Cumberland County (Rooney, 1971). A hydrologic study of the unconfined aquifers in most of Salem County and the southwestern part of Gloucester County is presented in Johnson and Charles (1997). Watt and Johnson (1992) describe the hydrology of the unconfined KirkwoodCohansey aquifer system in the Great Egg Harbor River Basin. The hydrology of the unconfined aquifer system in the upper Maurice River Basin is presented in Lacombe and Rosman (1995). Charles and others (2001) investigated the hydrology of the unconfined Kirkwood-Cohansey aquifer system across the entire Maurice and Cohansey River Basins. Cauller and others (1999) described the hydrogeology of, and ground-water withdrawals from, the major aquifers in Salem and Gloucester Counties. A comprehensive description of the hydrogeology of the entire Coastal Plain of New Jersey can be found in Zapecza (1989). The geology of the Kirkwood Formation is described in Isphording (1970), and the geology of more recent surficial deposits is described in Owens and Minard (1979). The bedrock geology of central and southern New Jersey is described in detail in Owens and others (1998). The surficial geology of southern New Jersey is described in detail in Newell and others (2000).

\section{Well-numbering system}

The well-numbering system used in this report has been used by the USGS in New Jersey since 1978. The well number consists of a county code number and a sequence number. County code numbers used in this report are 1-Atlantic, 7-Camden, 11-Cumberland, 15-Gloucester, and 33Salem. For example, well 15-764 is the 764th well inventoried in Gloucester County.

\section{Hydrogeologic Framework and Ground-Water Flow}

The geology of southern New Jersey consists of a southeast-dipping wedge of unconsolidated Quaternary, Tertiary, and Upper Cretaceous sediments. A generalized section through the geologic formations investigated is shown in figure 4. The geologic units studied consist of surficial deposits of alluvium and colluvium, the Bridgeton Formation, the Cohansey Formation, and the Belleplain Member, Wildwood Member, Shiloh Marl, and lower member of the Kirkwood Formation. The combined thickness of the permeable Kirkwood Formation and younger unconsolidated sediments compose the unconfined Kirkwood-Cohansey aquifer system in this area. The basal part of the Kirkwood Formation is a regionally extensive clay layer that is included in the composite confining bed (Zapecza, 1989). The composite confining bed separates the Kirkwood-Cohansey aquifer system from the deeper, confined aquifers. The stratigraphy of the geologic units investigated in this study and the composite confining bed that underlies the Kirkwood-Cohansey aquifer system are presented in table 1 .

\section{Geologic setting}

Holocene-age alluvium and colluvium exposed at the surface consist of gravel, sand, silt, and clay and are primarily reworked sediments of the underlying Bridgeton and Cohansey Formations. The Bridgeton Formation is an arkosic sand with local lenses of fine gravel that were deposited in a fluvial environment. Its sediments are thin and patchy (Owens and Minard, 1979). The Cohansey Formation is white, yellow, or gray medium sand that weathers to yellow, brown, red, or orange (Owens and others, 1998) and contains discontinuous interbedded clays. The Cohansey Formation has an irregular basal contact and unconformably overlies the Kirkwood Formation. The Kirkwood Formation is a fine to medium, white to pale gray sand that weathers to dark yellow, orange, brown, or red (Owens and others, 1998). In the subsurface, the lower part of the formation is principally dark gray, massive clay. Owens and others (1998) subdivided the Kirkwood Formation into four members, from youngest to oldest: the Belleplain, Wildwood, Shiloh Marl, and lower. In the study area, the 


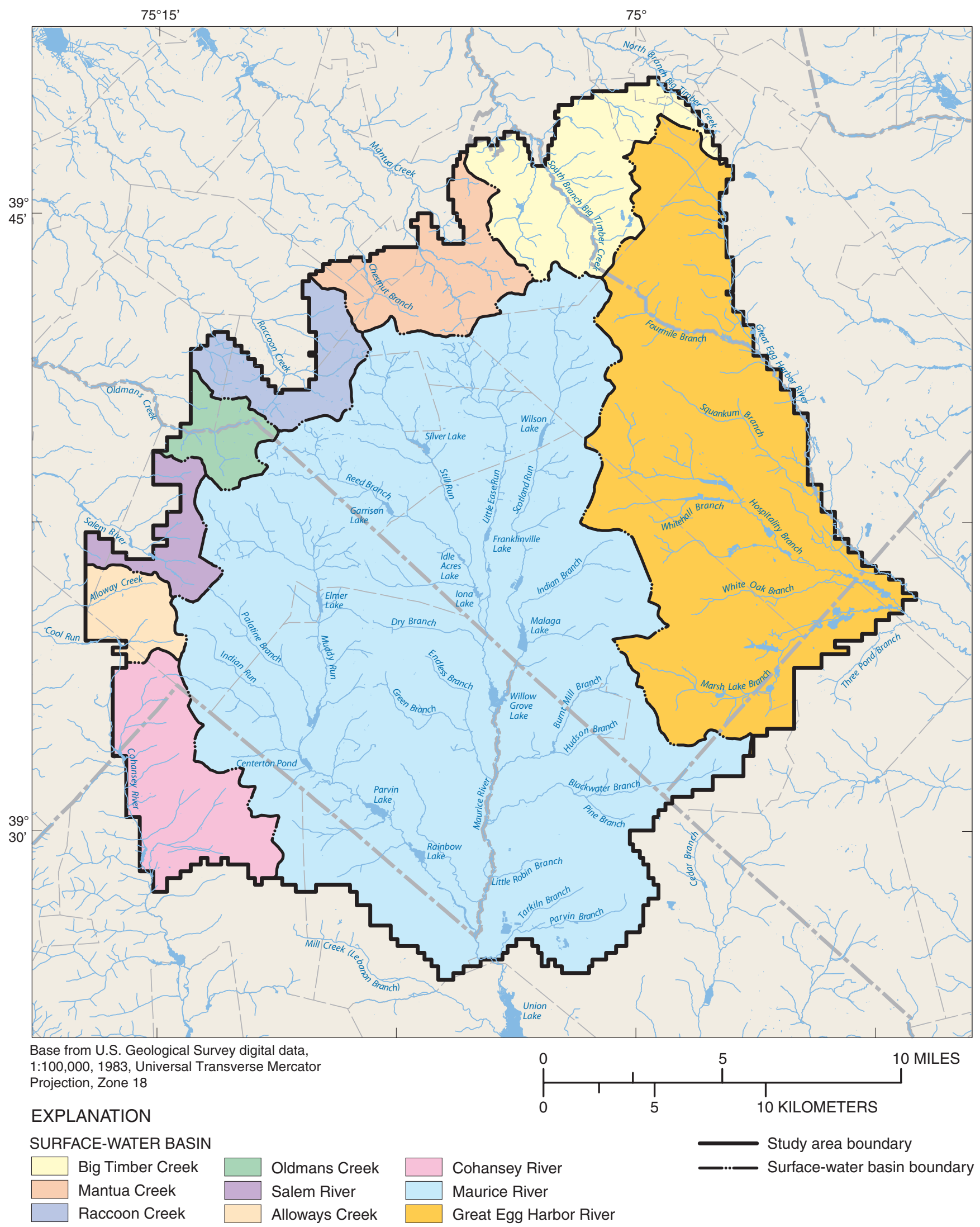

Figure 3. Location of surface-water basins, upper Maurice River Basin area, N.J. 


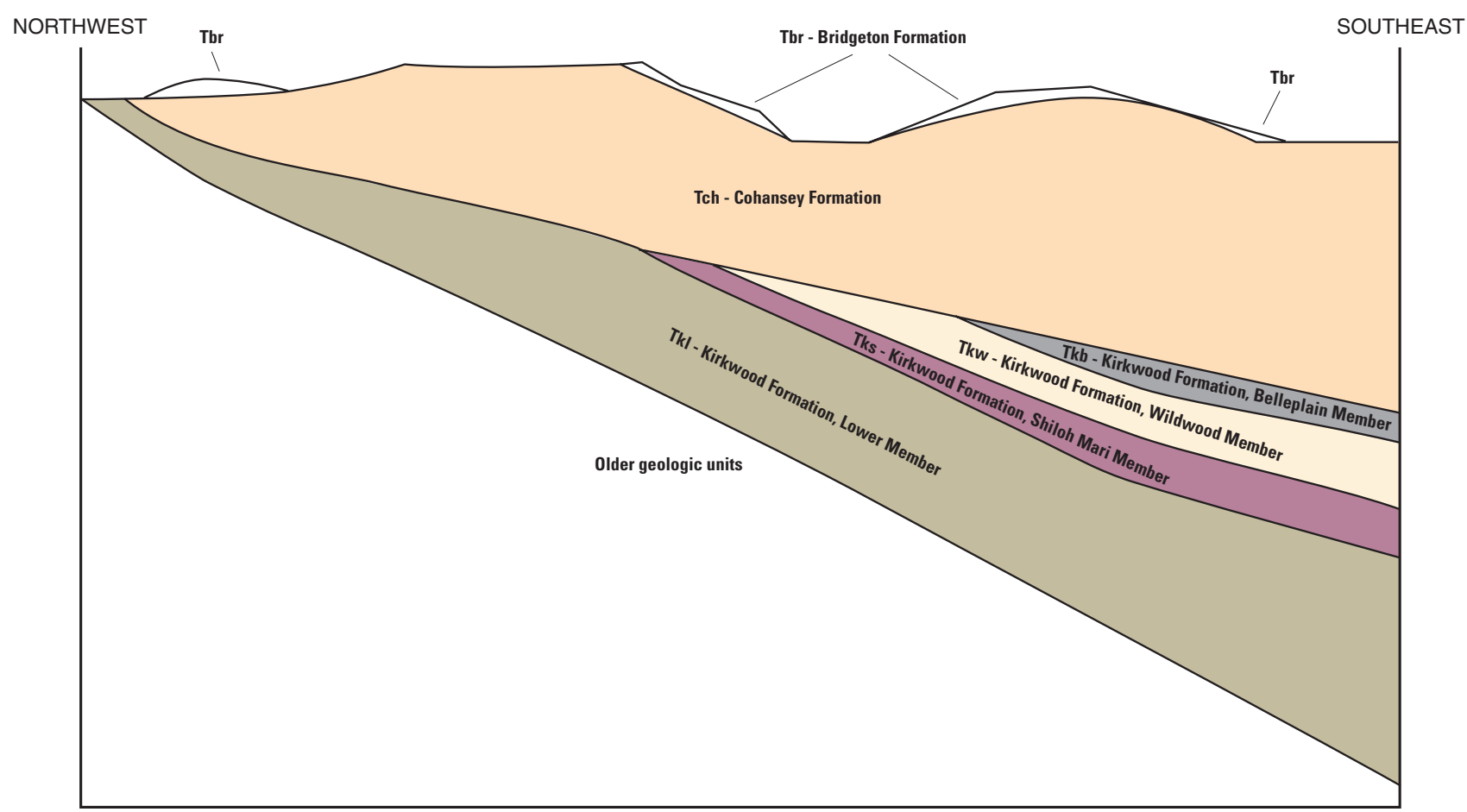

NOT TO SCALE

Figure 4. Generalized stratigraphic section through the Kirkwood-Cohansey aquifer system, upper Maurice River Basin area, N.J.

Kirkwood Formation consists almost entirely of the lower member. As the formation thickens to the southeast, it includes additional depositional facies represented by the younger members. Near the southern boundary of the study area, west of Union Lake, the Kirkwood Formation consists of the Wildwood Member, Shiloh Marl Member and lower member, and near Buena Borough, it is comprised of the Shiloh Marl Member and lower member. The lower member consists of an upper sand facies referred to as the Grenloch sand (Isphording, 1970) and a lower clay facies known as the Alloway clay (Kummel and Knapp, 1904). The lower member of the Kirkwood Formation unconformably overlies the Vincentown, Manasquan, Shark River, Absecon Inlet, and Atlantic City Formations (table 1) from northwest to southeast in the study area (Owens and others, 1998). In general, Cohansey Formation sediments are present at the surface in bands that parallel the surface-water drainages, and Bridgeton Formation sediments mantle the interstream areas (Newell and others, 2000).

\section{Kirkwood-Cohansey aquifer system}

The Kirkwood-Cohansey aquifer system is composed of the saturated parts of Holocene-age alluvial and colluvial deposits, the Bridgeton Formation of late Miocene age, the Cohansey Formation of middle Miocene age, and sandy parts of the Kirkwood Formation of early and middle Miocene age. The aquifer system is unconfined in this part of southern New Jersey. The base of the aquifer system coincides with the lower clay facies of the Kirkwood Formation's lower member. The lower member forms the top of the composite-confining bed, which marks the lower boundary of the ground-water flow model.

The altitude of the base of the Kirkwood-Cohansey aquifer system ranges from land surface at the western extent of the outcrop area (near the northern border of the study area) to $150 \mathrm{ft}$ below NGVD of 1929 at the southeastern boundary of Gloucester County. The aquifer system thins to a featheredge at the western extent of the outcrop area (just outside the study area) and thickens to $250 \mathrm{ft}$ at the Gloucester County/Atlantic County boundary (fig. 5).

\section{Aquifer properties}

On the basis of aquifer tests conducted in Gloucester and Salem Counties, the hydraulic conductivity of the KirkwoodCohansey aquifer system ranges from 90 to $250 \mathrm{ft} / \mathrm{d}$ and the transmissivity ranges from 4,000 to $8,300 \mathrm{ft}^{2} / \mathrm{d}$ (Rhodehamel, 1973). The same tests indicated storage coefficients of $3 \times 10^{-4}$ and $1.0 \times 10^{-3}$, indicative of semiconfined conditions.

\section{Recharge}

A water budget of the hydrologic system in the Maurice River Basin based on precipitation records for 1985-94 is presented in Charles and others (2001). The objective of the water budget is to estimate the annual rate of recharge to the ground- 
Table 1. Stratigraphy and hydrogeologic units, upper Maurice River Basin area, N.J.

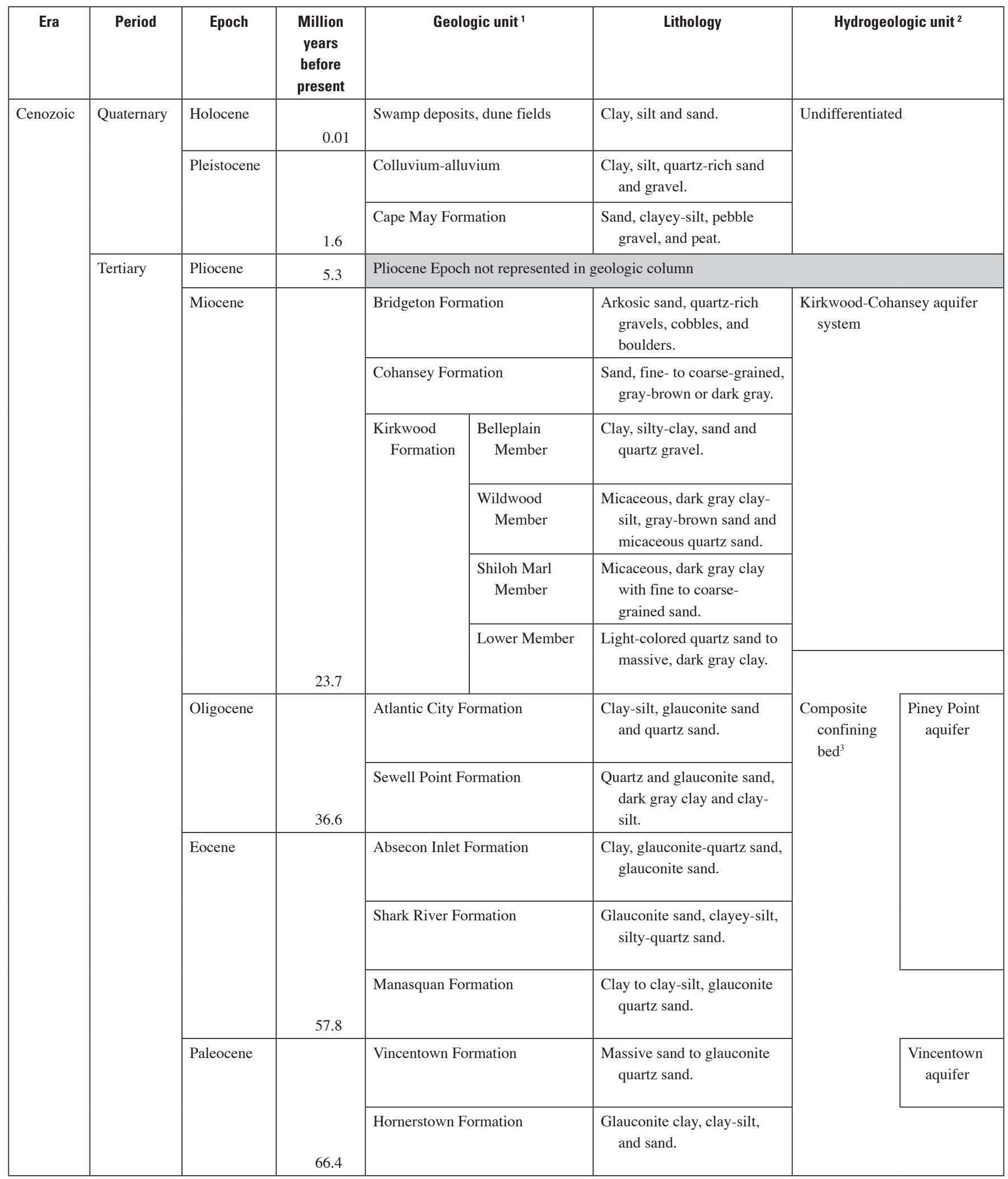

${ }^{1}$ Nomenclature from Owens and others, 1998; Newell and others, 2000.

${ }^{2}$ Nomenclature from Zapecza, 1989.

${ }^{3}$ Includes older geologic units not shown in table. 


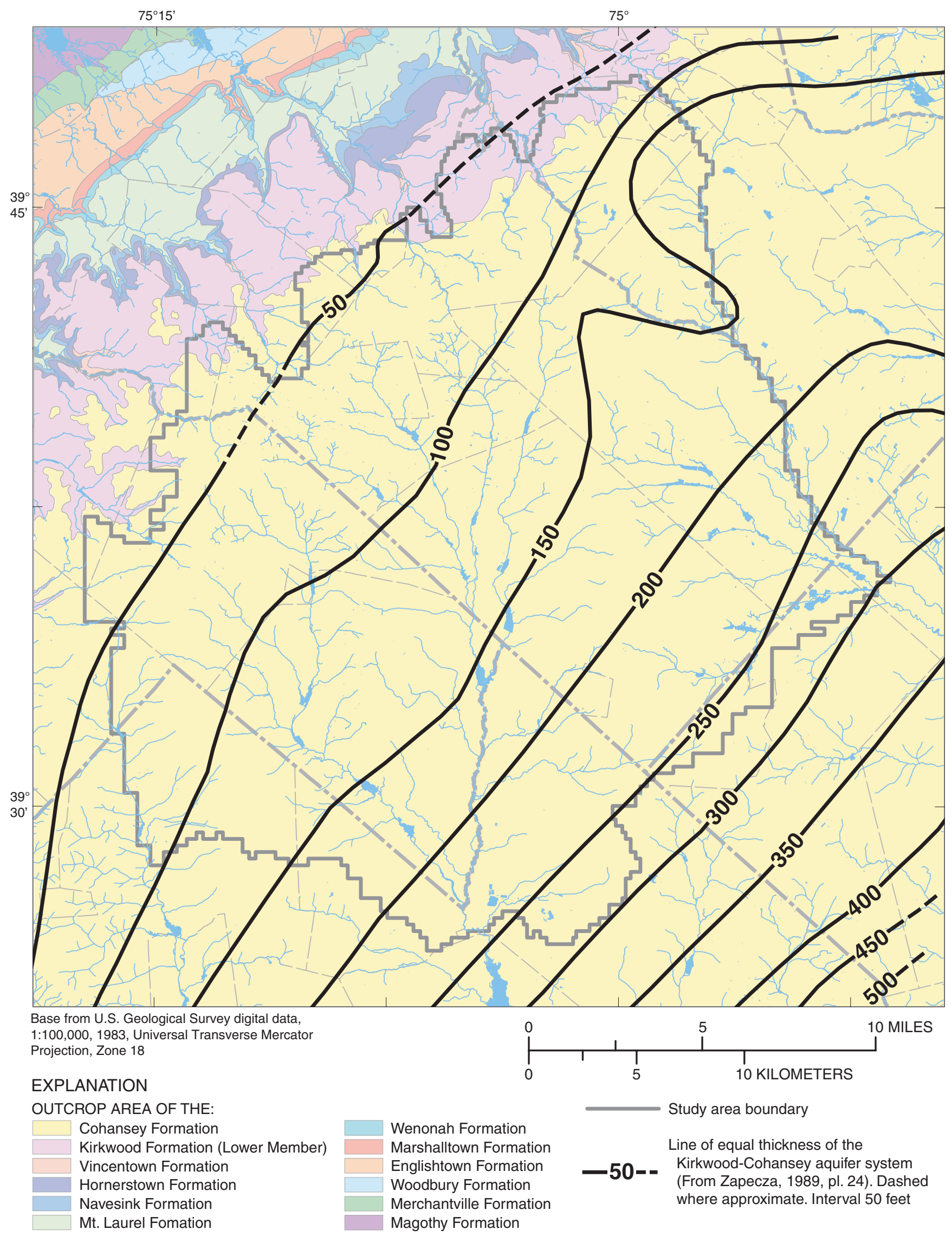

Figure 5. Thickness of the Kirkwood-Cohansey aquifer system, upper Maurice River Basin area, N.J. 
water flow system. The average annual natural recharge to the unconfined Kirkwood-Cohansey aquifer system in the Maurice River Basin was calculated as 16.2 in/yr (Charles and others, 2001). Johnson and Charles (1997) applied the same methodology to determine a recharge rate of $13.03 \mathrm{in} / \mathrm{yr}$ to the unconfined Kirkwood-Cohansey aquifer system in the Alloway Creek, Salem River, Oldmans Creek, and Raccoon Creek Basins (fig. 3). Using the same method, Lacombe and Rosman (1995) calculated a recharge rate of $18.57 \mathrm{in} / \mathrm{yr}$ to the Kirkwood-Cohansey aquifer system in the upper parts of the Raccoon Creek, Mantua Creek, Big Timber Creek, and Maurice River Basins. Watt and Johnson (1992) derived a recharge rate of $18.3 \mathrm{in} / \mathrm{yr}$ in the Great Egg Harbor River Basin, and Charles and others (2001) calculated a rate of natural recharge of 14.6 in/yr to the unconfined Kirkwood-Cohansey aquifer system in the Cohansey River Basin. Recharge rates determined in the aforementioned studies were applied to the respective part of each surface-water basin within the study area in steady-state model simulations.

\section{Water use}

Water use within a given geographic area varies monthly and yearly as a result of population changes, variable climatic and economic conditions, ground- and surface-water contamination issues, and legislative actions that mandate certain restrictions on use. A growing population in southern New Jersey has led water-supply purveyors to rely on the Kirkwood-Cohansey aquifer system in the study area to meet the increasing water demand.

Records of water use in New Jersey are compiled on a yearly basis by the NJDEP, Bureau of Water Supply. Any owner of a well with a pump capacity of $70 \mathrm{gal} / \mathrm{min}$ or greater is required by NJDEP to report total monthly water use from each withdrawal point on a yearly basis. Owners of private domestic wells are not required to report summaries of their water use to NJDEP. Therefore, amounts withdrawn for domestic use are not included in this study. As a result of the reporting requirements, the NJDEP maintains a file of all reported water use within the State. Wells are categorized by type of water use and pump capacity, and are assigned to a water allocation permit series. The allocation permit series used by NJDEP and the total number of wells in each permit series located in the study area are shown in table 2 . Wells in the $5000,2000 \mathrm{P}$ and $10000 \mathrm{~W}$ permit series are required to have a meter that measures the quantity of water extracted. Wells that operate under an agricultural certification are not required to meter the quantity of water extracted. In this instance, the well owner is required to submit monthly estimates of water use on an annual basis to NJDEP. These values are considered less accurate than metered quantities. Estimates are based on pump capacity multiplied by the number of hours the pump was in operation.

The geographic distribution of the reported ground-water withdrawals and the relative magnitude of the average annual withdrawals for the years 1990-96 are illustrated in figure 6 . Owners of 565 wells in the study area have been granted allocation permits to withdraw water from the Kirkwood-Cohansey aquifer system. Eighty-four wells are designated high-volume withdrawals. Most public-supply withdrawals are located in the northeastern and southeastern parts of the study area. These withdrawals correspond to population centers in Washington, Gloucester, Winslow, and northern Monroe Townships to the north and the City of Vineland to the south. There are 379 agricultural withdrawal wells located predominantly in the southern part of the study area.

Total annual withdrawals from each well were computed for 1990 through 1996. Annual withdrawals from wells by water allocation permit series for the 7-year period are shown in figure 7. Reported annual withdrawals from the KirkwoodCohansey aquifer system ranged from 6.48 billion gallons in 1990 to more than 10 billion gallons in 1995 in this area. Monthly withdrawals at every well in the study area were tabulated for January 1994 through March 1997.

\section{Ground-water levels}

Ground-water levels in the unconfined KirkwoodCohansey aquifer system are affected by conditions such as climatic changes that ultimately control the rate and amount of recharge to the aquifer and pumping stresses that remove ground water from the aquifer. At any given location, the water-table altitude varies from day to day, although the scale of that variation due to natural conditions is generally in the range of tenths to hundredths of a foot. A composite water table map is shown in figure 8 . The map illustrates water-table altitudes in the study area, which are derived primarily from water-level data collected in 1995 in the Cohansey and Mau-

Table 2. Ground-water allocation permit series.

[gal/d, gallons per day; <, less than; >, greater than]

\begin{tabular}{lllr}
\hline Allocation permit series & Magnitude of withdrawal & Primary use & $\begin{array}{c}\text { Number of wells in } \\
\text { study area }\end{array}$ \\
\hline 5000 & High volume $(>100,000 \mathrm{gal} / \mathrm{d})$ & Public supply & 40 \\
$2000 \mathrm{P}$ & High volume $(>100,000 \mathrm{gal} / \mathrm{d})$ & Industrial, commercial & 44 \\
$10000 \mathrm{~W}$ & Low volume $(<100,000 \mathrm{gal} / \mathrm{d})$ & Institutional, recreation & 102 \\
Agricultural certifications & Variable & Irrigation & 379 \\
\hline
\end{tabular}




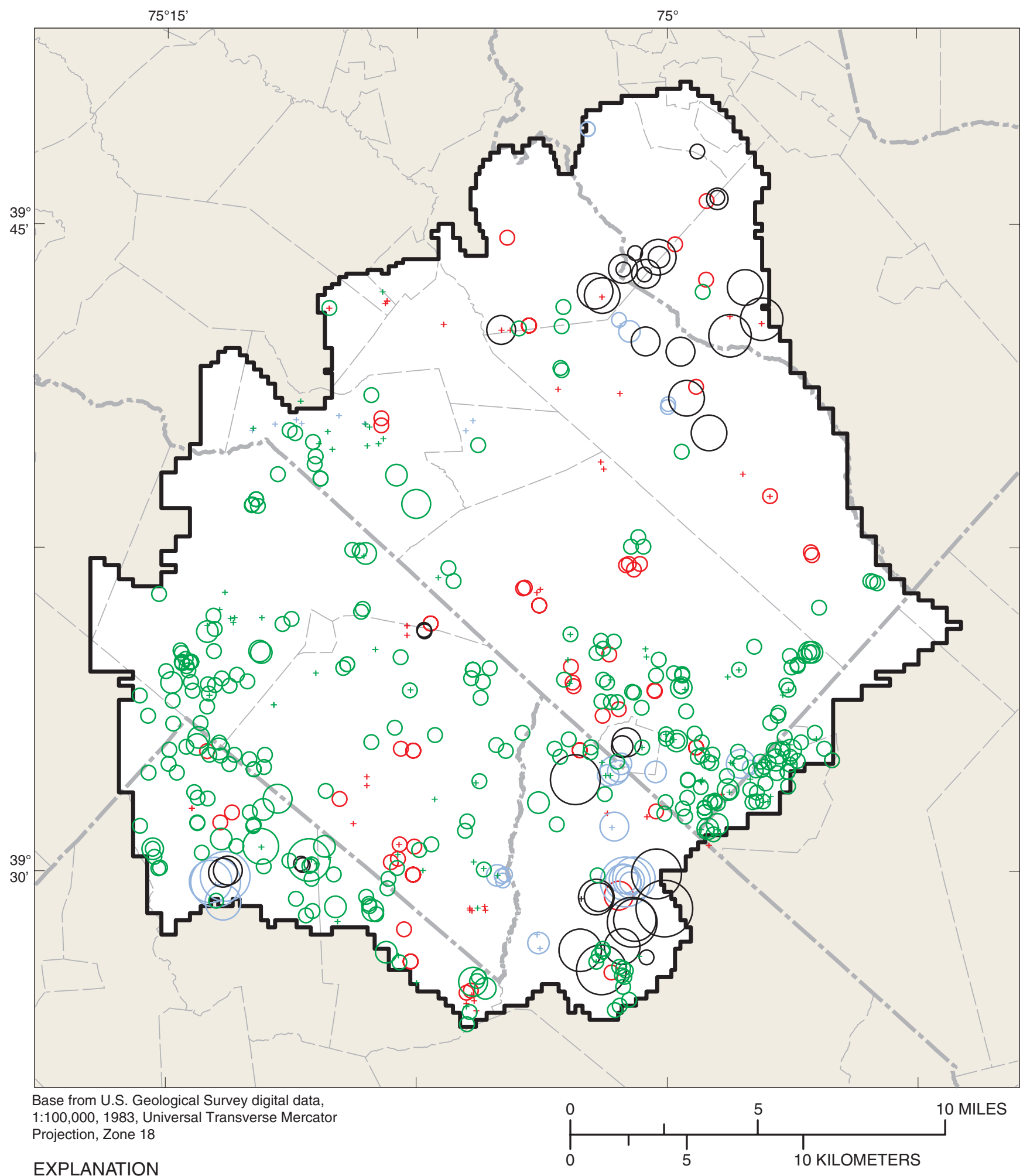

EXPLANATION

Study area boundary

Well location and mean annual withdrawal during 1990-96, in million gallons per year. Color indicates water

use: black - public supply, blue - industrial, red - low-volume institutional, and green - agriculture and horticulture

$>$, greater than
$+0$
O >0-20
○ $>50-100$
> $>20-50$
C $>100-200$

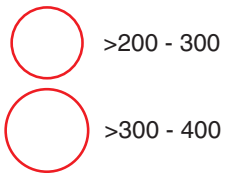

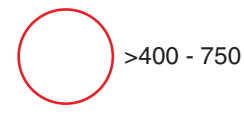

Figure 6. Location of wells screened in the Kirkwood-Cohansey aquifer system with reported mean annual withdrawals during $1990-96$. 


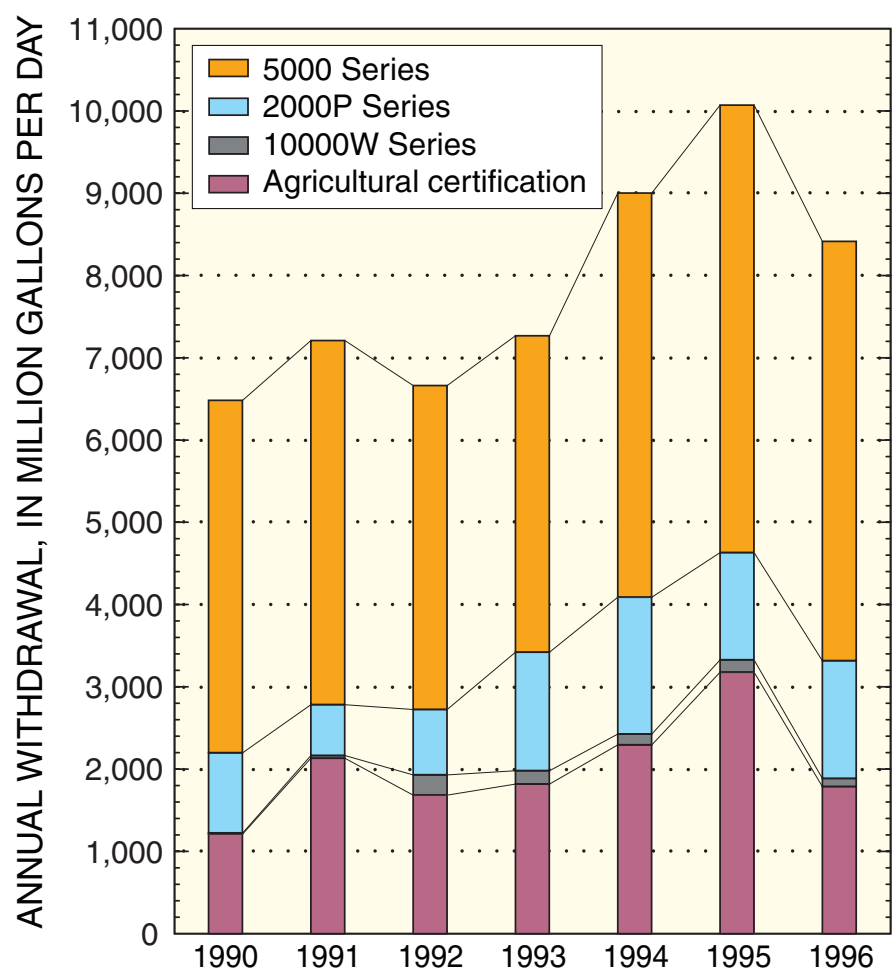

Figure 7. Reported annual ground-water withdrawals by water allocation permit series, upper Maurice River Basin area, N.J., 1990-96.

rice River Basins (Charles and others, 2001). Water-level data for the surface-water basins that drain into the Delaware River, specifically Salem River, Alloway Creek, Oldmans Creek, Raccoon Creek, Mantua Creek, and Big Timber Creek, (fig. 3) were collected during 1993 (Johnson and Charles, 1997) and 1986 (Lacombe and Rosman, 1995). Water-level data for the Great Egg Harbor River Basin were collected during 1989 (Watt and Johnson, 1992). The water table mirrors the topography, typical of an unconfined aquifer composed of unconsolidated sediments. The highest water-table altitudes occur along a band that roughly parallels the northern boundary of the study area. This area is the major basin divide between the Maurice and Great Egg Harbor Rivers that drain to the south and the Alloway Creek, Salem River, Raccoon Creek, Mantua Creek, and Big Timber Creek that drain to the north into the Delaware River. Contour lines bend upstream throughout the study area, indicating that streams are gaining sizable components of their flow from the ground-water flow system. The lowest altitude of the ground-water table occurs along the main stem of the Maurice River at the southern boundary, coincident with the topographic low in the study area. Contours are closely spaced near the northern boundary of the study area where the ground-water gradient is steepest and widely spaced along the divide of the Maurice River Basin.

Ground-water levels were recorded at 46 wells (point measurements) throughout the study area (fig. 9). Observation wells that were largely unaffected by human-derived recharge or withdrawals were selected to monitor water levels wherever possible. Water levels in 43 wells were measured monthly from January 1995 through March 1997. Water levels in three wells were recorded at 15-minute increments by use of continuous recorders. Well-construction data and the range of water levels at each well are presented in table 3. Hydrographs of several wells in the Maurice River Basin (fig. 10) demonstrate the range of variation in the water table over the measurement period, illustrating the effects of the seasonal fluctuations of recharge coupled with extended wet and dry periods. October 1994 through September 1995 was a relatively dry period, averaging 2.75 inches of precipitation per month, as recorded at the Glassboro, N.J., weather station. Rainfall from October 1995 through March 1997 at the Glassboro, N.J., weather station was above normal, averaging 4.76 inches of precipitation per month.

\section{Ground-Water Flow Model Development}

A three-dimensional ground-water flow model of the Kirkwood-Cohansey aquifer system was developed by creating a mathematical representation of the regional unconfined flow system. The objective of using the flow model was to simulate ground-water flow and head distribution under various withdrawal strategies. These strategies address several projections of growth in this part of New Jersey and the subsequent demand that would be placed on the ground-water resources. Boundaries of the flow model correspond to natural hydrologic features. The mathematical representation of the hydrologic system was developed by using MODFLOW, a finite-difference ground-water flow model code written by McDonald and Harbaugh (1988). The computer code was revised and updated by Harbaugh and others (2000).

\section{Aquifer geometry and model grid}

The study area is composed predominantly of the Bridgeton Formation, the Cohansey Formation, and the Lower Member of the Kirkwood Formation, which collectively comprise the Kirkwood-Cohansey aquifer system. The extent, thickness, and structure of the underlying geologic units that comprise the Kirkwood-Cohansey aquifer system were determined by examination of 202 geophysical well logs and drillers' well records. Detailed examinations of logs and the correlation of identifiable geologic units provided the information to construct a three-dimensional representation of subsurface materials by defining three model layers. In general, model layers correspond to different geologic materials and represent distinct lithologic units that have an appreciable areal extent (fig. 11). Model layer 1 represents homogeneous sand except in the northeastern part of the model where finer-grained silt is 


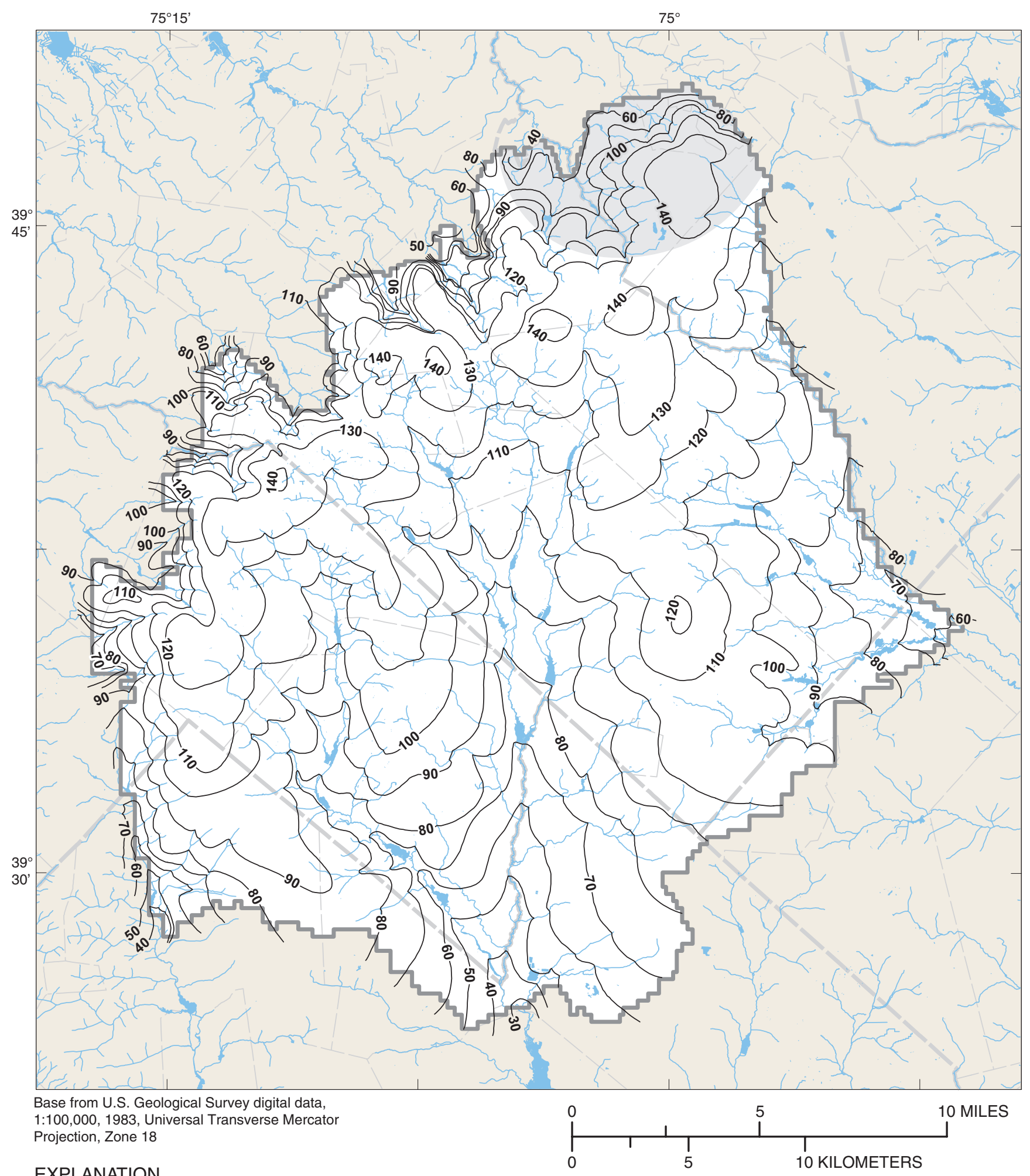

\section{EXPLANATION}

Limited ground-water elevation data in this area. Water Table contour interval 20 feet Study area boundary

_ $\mathbf{8 0}$ Water Table - Contour interval 10 feet (From Charles and others, 2001), except where noted

Figure 8. Composite water-table of the Kirkwood-Cohansey aquifer system, upper Maurice River Basin area, N.J. 


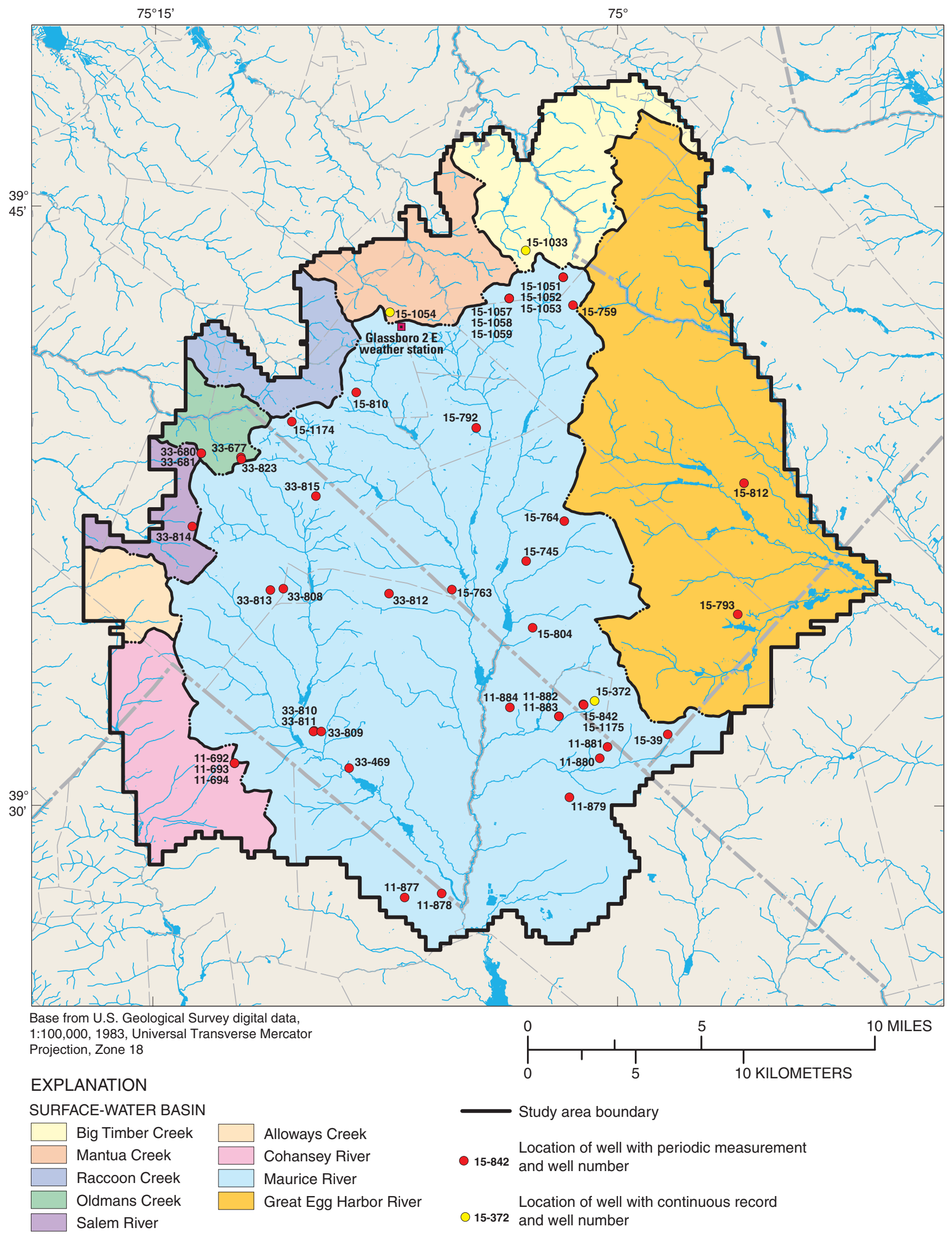

Figure 9. Location of observation wells, upper Maurice River Basin area, N.J. 


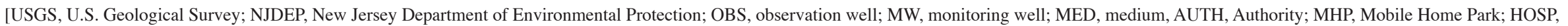
Hospital; HS, high school; IRR, irrigation; SLF, sanitary landfill; FLD, field; BORO, Borough; TWP, Township; NAD83, North American Datum of 1983; NAD27, North American Datum of 1927; NGVD29,

National Geodetic Vertical Datum of 1929; --, no data; lat, latitude; long, longitude]

\begin{tabular}{|c|c|c|c|c|c|c|c|c|c|c|c|c|c|}
\hline $\begin{array}{c}\text { USGS } \\
\text { well } \\
\text { number }\end{array}$ & Local well number & $\begin{array}{l}\text { NJDEP } \\
\text { permit } \\
\text { number }\end{array}$ & $\begin{array}{l}\text { Latitude } \\
\text { (DDMMSS) }\end{array}$ & $\begin{array}{l}\text { Longitude } \\
\text { (DDMMSS) }\end{array}$ & $\begin{array}{l}\text { Lat/long } \\
\text { datum } \\
\text { (code) }\end{array}$ & Township & $\begin{array}{l}\text { Date well } \\
\text { constructed }\end{array}$ & $\begin{array}{c}\text { Altitude } \\
\text { of land } \\
\text { surface } \\
\text { (feet) }\end{array}$ & $\begin{array}{l}\text { Altitude } \\
\text { datum } \\
\text { (code) }\end{array}$ & $\begin{array}{l}\text { Depth of } \\
\text { well, in feet } \\
\text { below land } \\
\text { surface }\end{array}$ & $\begin{array}{l}\text { Top of open } \\
\text { interval, in } \\
\text { feet below } \\
\text { land surface }\end{array}$ & $\begin{array}{c}\text { Bottom of } \\
\text { open inter- } \\
\text { val, in feet } \\
\text { below land } \\
\text { surface }\end{array}$ & $\begin{array}{c}\text { Range in } \\
\text { water level } \\
\text { (feet) }\end{array}$ \\
\hline 11-692 & USGS AG06 RUTGERS 1S OBS & $34-03742.1$ & 393058.5 & 751219.1 & NAD83 & UPPER DEERFIELD TWP & 09-28-1990 & 119.62 & NGVD29 & 38 & 33 & 38 & $92.28-98.67$ \\
\hline $11-693$ & RUTGERS R\&D2 MED OBS & $34-03743$ & 393104 & 751222 & NAD27 & UPPER DEERFIELD TWP & 09-27-1990 & 119.67 & NGVD29 & 78 & 73 & 78 & $92.26-98.64$ \\
\hline $11-694$ & RUTGERS R\&D3 DEEP OBS & 34-03744 & 393104 & 751222 & NAD27 & UPPER DEERFIELD TWP & 09-26-1990 & 119.95 & NGVD29 & 115 & 105 & 110 & 92.19-98.57 \\
\hline $11-877$ & SUNNYSIDE FARMS MW-6 & $35-14969$ & 392743 & 750652 & NAD27 & DEERFIELD TWP & 08-25-1994 & 76.43 & NGVD29 & 25 & 5 & 25 & $61.71-66.81$ \\
\hline $11-878$ & LANDIS SEWERAGE AUTH MW & $35-02829$ & 392749 & 750540 & NAD27 & DEERFIELD TWP & 05-21-1981 & 61 & NGVD29 & 32 & 22 & 32 & $41.26-43.20$ \\
\hline $11-879$ & LAB GLASS MW-1 & $35-13318$ & 393013 & 750133 & NAD27 & VINELAND CITY & 09-08-1992 & 95 & NGVD29 & 27 & 7 & 27 & $74.98-79.85$ \\
\hline $11-880$ & CHAPMAN MHP MW-4 & $35-14197$ & 393112 & 750034 & NAD27 & VINELAND CITY & 08-13-1993 & 100.48 & NGVD29 & 22.2 & 12.2 & 22.2 & $83.00-87.39$ \\
\hline $11-881$ & CHAPMAN MHP MW-1 & $35-14194$ & 393129 & 750019 & NAD27 & VINELAND CITY & 08-13-1993 & 106.87 & NGVD29 & 24.62 & 14.62 & 24.62 & $86.94-92.22$ \\
\hline $11-882$ & SMC SC24S & $31-35435-1$ & 393215 & 750153 & NAD27 & VINELAND CITY & $11-28-1990$ & 91.71 & NGVD29 & 20 & 5 & 20 & $81.79-85.95$ \\
\hline $11-883$ & SMC SC24D & $31-42083$ & 393215 & 750153 & NAD27 & VINELAND CITY & 08-24-1993 & 91.66 & NGVD29 & 115 & 105 & 115 & $81.50-85.06$ \\
\hline $11-884$ & UPS MW-2/FLD TAG MW-5 & $31-39869$ & 393228 & 750328 & NAD27 & VINELAND CITY & 08-13-1992 & 80 & NGVD29 & 17.5 & 2.5 & 17.5 & $72.22-76.57$ \\
\hline $15-39$ & CIFALOGLIO IRR & $35-00933$ & 393148 & 745822 & NAD27 & FRANKLIN TWP & 03-00-1967 & 110 & NGVD29 & 123 & 75 & 123 & $98.31-105.20$ \\
\hline $15-372$ & NEWFIELD 2-A OBS & $31-06092$ & 393238 & 750044 & NAD27 & NEWFIELD BORO & 11-03-1969 & 120 & NGVD29 & 154 & 129 & 149 & $96.53-103.18$ \\
\hline $15-745$ & DUMP NORTH & -- & 393608 & 750257 & NAD27 & FRANKLIN TWP & 1985 & 124 & NGVD29 & 38 & -- & -- & $95.03-99.32$ \\
\hline $15-759$ & MESIANO 1 & -- & 394232 & 750126 & NAD27 & MONROE TWP & -- & 159 & NGVD29 & 135 & 130 & 135 & $136.65-143.22$ \\
\hline $15-763$ & MOORE 2 & -- & 393525 & 750521 & NAD27 & FRANKLIN TWP & -- & 109 & NGVD29 & 60 & 55 & 60 & $87.47-92.00$ \\
\hline $15-764$ & SCAFONIS D & -- & 393708 & 750143 & NAD27 & FRANKLIN TWP & -- & 130 & NGVD29 & 49 & 44 & 49 & $107.62-114.03$ \\
\hline $15-792$ & PP1 & -- & 393928 & 750434 & NAD27 & CLAYTON BORO & -- & 120 & NGVD29 & 75 & 65 & 75 & $108.23-112.96$ \\
\hline $15-793$ & FERRUCCI 10 & 31-21192 & 393448 & 745606 & NAD27 & FRANKLIN TWP & 05-14-1984 & 110 & NGVD29 & 150 & 100 & 150 & $93.67-100.28$ \\
\hline $15-804$ & MALAGA 1 & 31-22013 & 393428 & 750244 & NAD27 & FRANKLIN TWP & 09-06-1984 & 110 & NGVD29 & 123 & 95 & 123 & $78.06-80.95$ \\
\hline $15-810$ & ELK 1 & $31-17796$ & 394021 & 750827 & NAD27 & ELK TWP & 02-11-1981 & 144 & NGVD29 & 63 & 53 & 63 & $125.68-131.71$ \\
\hline $15-812$ & CORONA 1 & -- & 393805 & 745554 & NAD27 & MONROE TWP & $12-00-1982$ & 123 & NGVD29 & 110 & 100 & 110 & $93.02-97.17$ \\
\hline $15-842$ & SA MW3 & 31-25759 & 393234 & 750113 & NAD27 & NEWFIELD BORO & -- & 105.78 & NGVD29 & 111 & 91 & 111 & $89.45-94.72$ \\
\hline $15-1033$ & WTMUA MONITORING 1 OBS & $31-31399$ & 394354 & 750259 & NAD27 & WASHINGTON TWP & 07-24-1989 & 150 & NGVD29 & 54 & 44 & 54 & $132.05-136.44$ \\
\hline 15-1051 & USGS WTMUA OBS-1 SHALLOW & $31-33952$ & 394314 & 750145 & NAD27 & WASHINGTON TWP & 05-25-1990 & 152.17 & NGVD29 & 27 & 22 & 27 & $135.02-140.95$ \\
\hline 15-1052 & USGS WTMUA OBS-2 MED & $31-33953$ & 394314 & 750145 & NAD27 & WASHINGTON TWP & 05-24-1990 & 152.16 & NGVD29 & 65 & 60 & 65 & $135.03-140.92$ \\
\hline $15-1053$ & USGS WTMUA OBS-3 DEEP & $31-33954$ & 394314 & 750145 & NAD27 & WASHINGTON TWP & 05-23-1990 & 152.18 & NGVD29 & 97 & 92 & 97 & $135.03-140.90$ \\
\hline 15-1054 & USGS GSC OBS SHALLOW & 31-33949 & 394221 & 750722 & NAD27 & GLASSBORO BORO & 06-05-1990 & 153.9 & NGVD29 & 36 & 31 & 36 & $131.01-137.53$ \\
\hline 15-1057 & USGS TPE OBS-1 SHALLOW & $31-33946$ & 394242 & 750330 & NAD27 & WASHINGTON TWP & 05-18-1990 & 155.89 & NGVD29 & 27 & 22 & 27 & $136.12-142.58$ \\
\hline $15-1058$ & USGS TPE OBS-2 MED-DEEP & $31-33947$ & 394242 & 750330 & NAD27 & WASHINGTON TWP & $05-22-1990$ & 156.2 & NGVD29 & 75 & 70 & 75 & $136.18-142.67$ \\
\hline
\end{tabular}


Table 3. Well construction data and range of water levels from January 1995 through March 1997 _Continued.

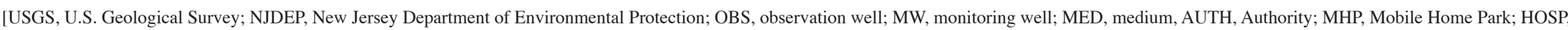
Hospital; HS, high school; IRR, irrigation; SLF, sanitary landfill; FLD, field; BORO, Borough; TWP, Township; NAD83, North American Datum of 1983; NAD27, North American Datum of 1927; NGVD29,

National Geodetic Vertical Datum of 1929; --, no data; lat, latitude; long, longitude]

\begin{tabular}{|c|c|c|c|c|c|c|c|c|c|c|c|c|c|}
\hline $\begin{array}{l}\text { USGS } \\
\text { well } \\
\text { number }\end{array}$ & Local well number & $\begin{array}{c}\text { NJDEP } \\
\text { permit } \\
\text { number }\end{array}$ & $\begin{array}{l}\text { Latitude } \\
\text { (DDMMSS) }\end{array}$ & $\begin{array}{l}\text { Longitude } \\
\text { (DDMMSS) }\end{array}$ & $\begin{array}{l}\text { Lat/long } \\
\text { datum } \\
\text { (code) }\end{array}$ & Township & $\begin{array}{l}\text { Date well } \\
\text { constructed }\end{array}$ & $\begin{array}{c}\text { Altitude } \\
\text { of land } \\
\text { surface } \\
\text { (feet) }\end{array}$ & $\begin{array}{l}\text { Altitude } \\
\text { datum } \\
\text { (code) }\end{array}$ & $\begin{array}{l}\text { Depth of } \\
\text { well, in feet } \\
\text { below land } \\
\text { surface }\end{array}$ & $\begin{array}{l}\text { Top of open } \\
\text { interval, in } \\
\text { feet below } \\
\text { land surface }\end{array}$ & $\begin{array}{l}\text { Bottom of } \\
\text { open inter- } \\
\text { val, in feet } \\
\text { below land } \\
\text { surface }\end{array}$ & $\begin{array}{c}\text { Range in } \\
\text { water level } \\
\text { (feet) }\end{array}$ \\
\hline 15-1059 & USGS TPE OBS-3 DEEP & $31-33948$ & 394242 & 750330 & NAD27 & WASHINGTON TWP & 05-17-1990 & 156.2 & NGVD29 & 100 & 95 & 100 & $136.18-142.68$ \\
\hline $15-1174$ & DEANS EVERGREENS 3 & $31-45447$ & 393937 & 751032 & NAD27 & ELK TWP & $12-20-1994$ & 140 & NGVD29 & 59 & 27 & 57 & $126.44-138.64$ \\
\hline $15-1175$ & SMC SC14S & $31-35215-4$ & 393233 & 750106 & NAD27 & NEWFIELD BORO & $11-15-1990$ & 105.93 & NGVD29 & 26.9 & 11.9 & 26.9 & $89.91-95.52$ \\
\hline $33-469$ & PARVIN PARK SHOP 1 & -- & 393057 & 750839 & NAD27 & PITTSGROVE TWP & 1984 & 75 & NGVD29 & 114 & 104 & 114 & $69.86-72.70$ \\
\hline $33-677$ & UPPER PITTS SLF MW1 & $30-03680-7$ & 393840 & 751212 & NAD27 & UPPER PITTSGROVE TWP & 05-07-1985 & 163.8 & NGVD29 & 40 & 20 & 40 & $132.02-140.01$ \\
\hline 33680 & USGS COLES FARM OBS-1 & $30-06586$ & 393848.2 & 751323.5 & NAD83 & UPPER PITTSGROVE TWP & 05-16-1990 & 144.35 & NGVD29 & 32 & 27 & 32 & $125.83-131.98$ \\
\hline $33-681$ & USGS COLES FARM OBS-2 & $30-06587$ & 393849 & 751328 & NAD27 & UPPER PITTSGROVE TWP & 05-15-1990 & 144.61 & NGVD29 & 45 & 40 & 45 & $125.84-131.99$ \\
\hline $33-808$ & ELMER HOSP MW-3A & $31-34188-8$ & 393526 & 751048 & NAD27 & ELMER BORO & 06-19-1990 & 124.23 & NGVD29 & 22.5 & 7.5 & 22.5 & $111.02-118.24$ \\
\hline $33-809$ & AP SCHALICK HS MW-1 & $35-10747-2$ & 393152 & 750934 & NAD27 & PITTSGROVE TWP & 07-31-1990 & 88.1 & NGVD29 & 25 & 5 & 25 & $78.57-84.71$ \\
\hline $33-810$ & AP SCHALICK HS MW-3 & $35-10749-9$ & 393152 & 750949 & NAD27 & PITTSGROVE TWP & 08-01-1990 & 105.95 & NGVD29 & 39 & 19 & 39 & $79.12-82.89$ \\
\hline $33-811$ & AP SCHALICK HS MW-2 & $35-10748-1$ & 393153 & 750948 & NAD27 & PITTSGROVE TWP & 08-01-1990 & 104.81 & NGVD29 & 39 & 19 & 39 & $79.37-83.19$ \\
\hline $33-812$ & HARDING WOODS MW-4 & $31-18825$ & 393519 & 750723 & NAD27 & PITTSGROVE TWP & $02-28-1982$ & 118.02 & NGVD29 & 24 & 14 & 24 & $106.84-112.20$ \\
\hline 33-813 & ELMER HOSP MW-1A & $31-34186-1$ & 393524 & 751113 & NAD27 & UPPER PITTSGROVE TWP & 06-18-1990 & 142.18 & NGVD29 & 35 & 20 & 35 & $114.45-122.26$ \\
\hline $33-814$ & N.J. BELL MW-1 & $30-04581$ & 393659 & 751345 & NAD27 & UPPER PITTSGROVE TWP & 03-31-1987 & 138 & NGVD29 & 18 & 3 & 18 & $125.52-133.14$ \\
\hline $33-815$ & MONROEVILLE PUB SCH MW-1 & $31-39698$ & 393745 & 750945 & NAD27 & UPPER PITTSGROVE TWP & 08-05-1992 & 135 & NGVD29 & 21 & 11 & 21 & $120.27-129.90$ \\
\hline $33-823$ & UPPER PITTS SLF MW2 & $30-03681-5$ & 393843 & 751211 & NAD27 & UPPER PITTSGROVE TWP & 05-09-1985 & 160 & NGVD29 & 39 & 19 & 39 & $132.53-140.51$ \\
\hline
\end{tabular}




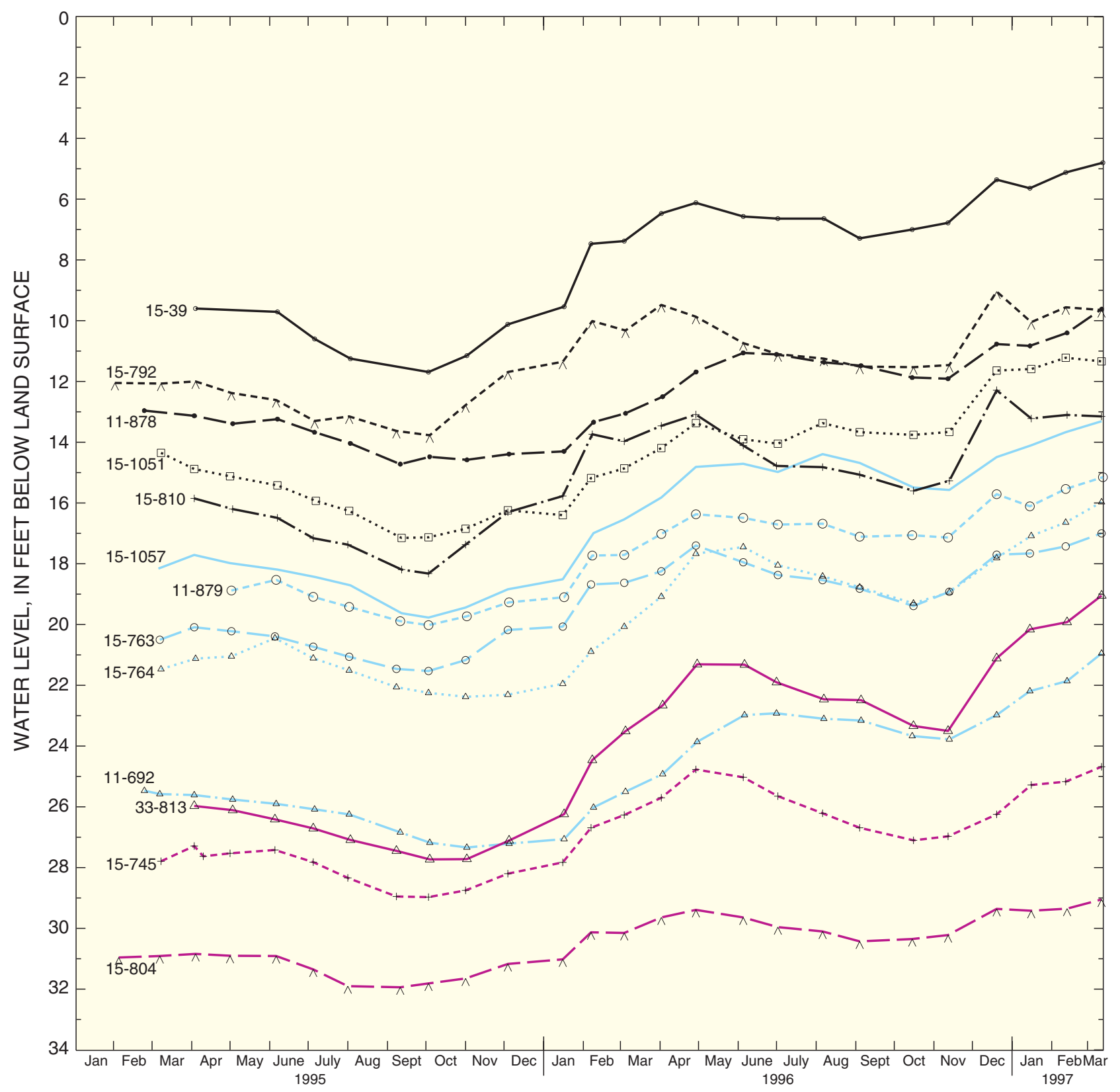

Figure 10. Water-level hydrographs for selected wells in the upper Maurice River Basin area, N.J., during 1995-97.

present. Well logs indicate the presence of discontinuous clay layers at depth with sand overlying and underlying the clay. Intermittent clay layers are more prevalent to the south where the sediments thicken and were represented by a continuous model layer (layer 2). The hydraulic conductivity of layer 2 was varied, based on the predominant composition - sand, mixed sand and clay, or clay. Model layer 3 represents uniform sand that underlies the clay layer.

The study area was discretized into a variably spaced grid of 150 columns and 169 rows (fig. 12). The grid is oriented north to south and is approximately 25.6 miles north to south and 24 miles east to west. The smallest cells are along the main branch of the Maurice River and are each $250 \mathrm{ft}$ east to west and $500 \mathrm{ft}$ north to south. Cell size gradually increases toward the edges of the grid, reaching a maximum cell size of $2,000 \mathrm{ft}$ east to west and 1,000 ft north to south. The smallest grid cells are located on or near the main branch of the Maurice River and in areas where public-supply wells are located in order to more accurately simulate the affect of single public-supply wells on the flow of ground water to the stream. The model grid consists of three layers discretized according to the dominant lithology. There are 18,588 active cells in each layer and 55,764 active cells in the entire model. 
NW
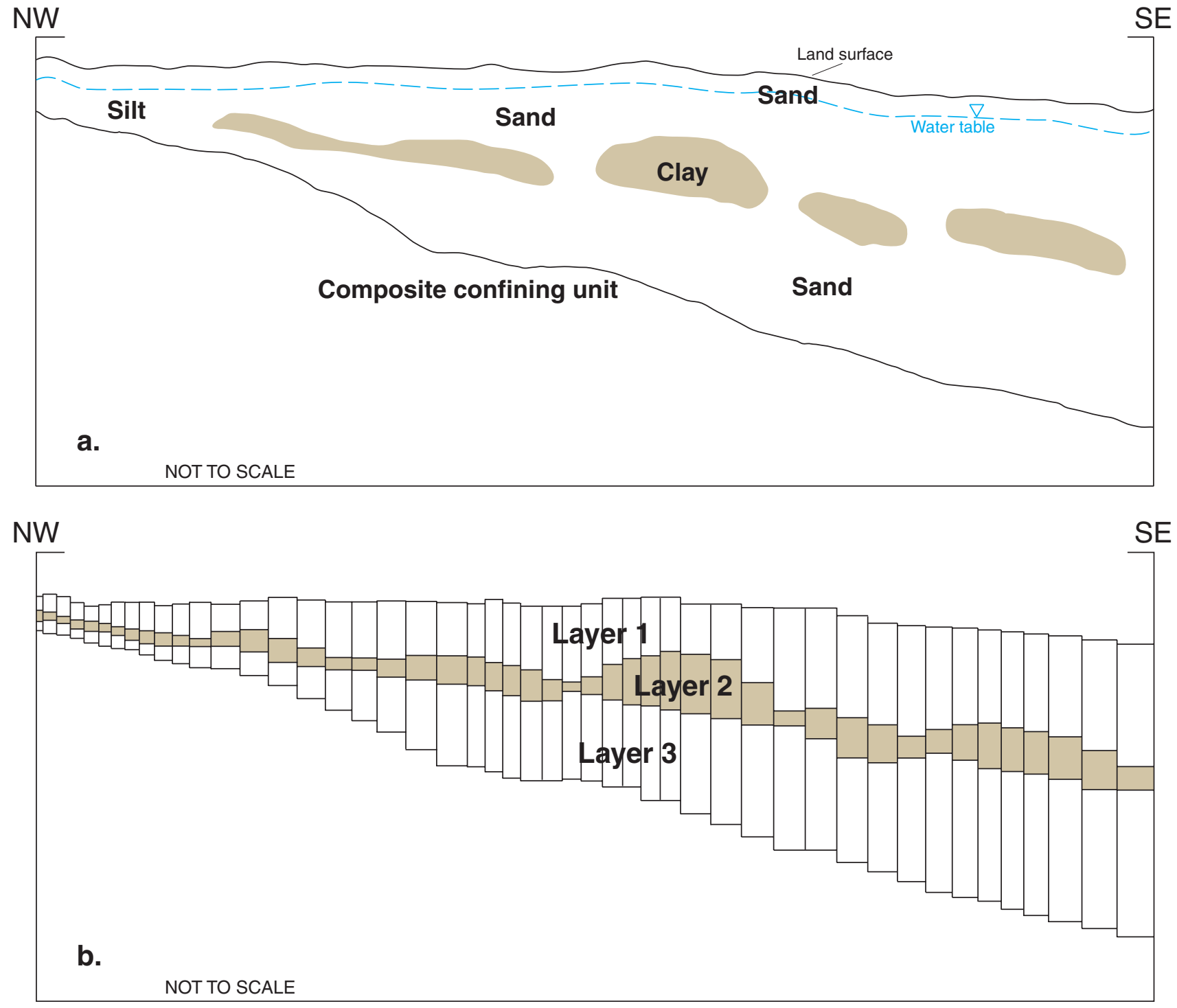

Figure 11. Diagrammatic section of (a) lithology, and (b) ground-water flow model layers in the upper Maurice River Basin area, N.J.

\section{Boundary conditions}

The boundaries of the flow model correspond to natural hydrologic boundaries. The lateral boundary of the groundwater flow model is coincident with streams adjacent to the Maurice River and is represented as a no-flow boundary. Extending the lateral boundary of the study area past the Maurice River Basin boundary allows the ground-water divide to shift beyond the surface-water divide when ground-water withdrawals are located at or near the basin boundary (surfacewater divide). The northern boundary corresponds to where the Kirkwood-Cohansey aquifer system is estimated to be 25 to $50 \mathrm{ft}$ thick (fig. 5). The aquifer system pinches out northwest of this area. The western boundary is the main channel of Alloway Creek and the Cohansey River farther to the south (fig. 3). The southern boundary conforms to several inner basin divides between Muddy Run and Lebanon Branch-Mill
Creek tributaries of the Maurice River and the divide between Marsh Lake Branch and Three Pond Branch tributaries of the Great Egg Harbor River (Hospitality Branch). The eastern boundary is the main channel of the Great Egg Harbor River to the south and North Branch of Big Timber Creek to the north. The bottom of the ground-water flow model is represented as a no-flow boundary that coincides with the top of the composite confining bed (Zapecza, 1989), a relatively impermeable clay layer consisting of several geologic units. The upper part of the composite confining bed consists of the clayey, lower part of the Kirkwood Formation. The top of the ground-water flow model is the water table. Recharge to the aquifer was varied by surface-water basin according to rates determined from several detailed basinwide water-budgets studies (see discussion in "Recharge" section) and ranged from 13.03 to $18.57 \mathrm{in} / \mathrm{yr}$. Streams were represented in the ground-water flow model as head-dependent-flow boundaries 


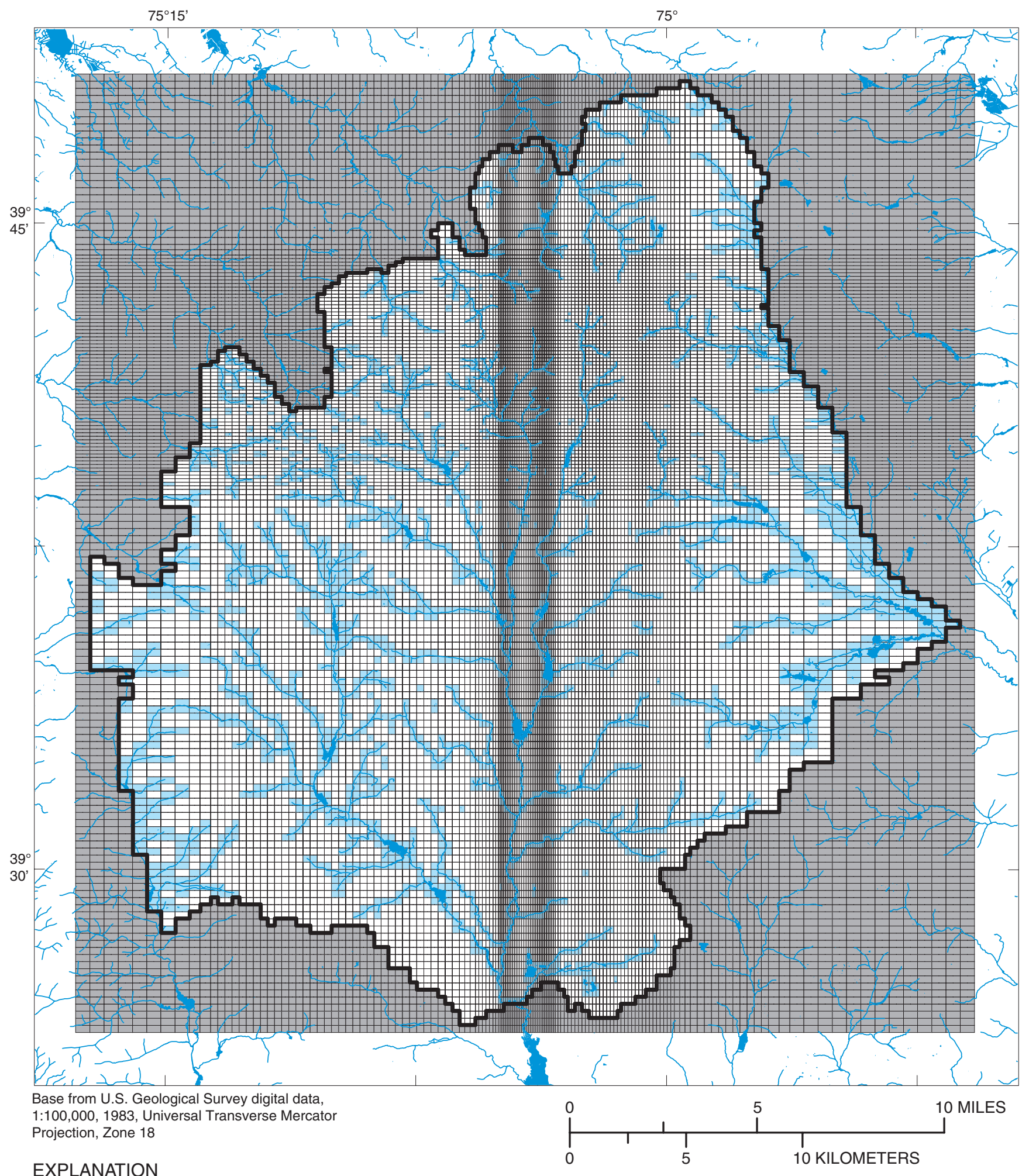

MODEL GRID

Head-dependend flux cell

Variable head cell

Inactive cell

Study area boundary

Figure 12. Variably-spaced model grid, lateral boundaries, and stream cells, upper Maurice River Basin area, N.J. 
and were simulated by using the river package in MODFLOW (McDonald and Harbaugh, 1988).

\section{Calibrated hydraulic properties}

Numerical estimates of the hydraulic conductivity, transmissivity, storage coefficient, and specific yield of the Kirkwood-Cohansey aquifer system have previously been reported in the literature. Reported values were used as initial estimates for the ground-water flow model. Vertical hydraulic conductivity was estimated to be one-tenth of the reported values of horizontal hydraulic conductivity. All values were modified during the calibration process. Calibrated hydrologic properties of the aquifer and semiconfining units used in the steadystate and transient ground-water flow models are presented in table 4. Values used in all model simulations are close to those reported from various aquifer tests of the KirkwoodCohansey aquifer system conducted in or near the study area (Rhodehamel, 1973; Charles and others, 2001). Model layer 1 was simulated as an unconfined layer, and layers 2 and 3 were simulated as fully convertible, permitting transmissivity to be recalculated for each iteration. Model layer 2 represents a discontinuous clay layer that acts as a semiconfining unit. Hydraulic properties for layer 2 (table 4) were applied in those areas where the clay unit is present, and properties of layer 1 were applied to layers 1 and 2 in those areas where sand is the predominant lithology.

\section{Steady-state calibration}

The ground-water flow model was calibrated to steadystate conditions for 1990-95. A trial-and-error process was used for the steady-state calibration to identify values of hydrologic properties that provided a reasonable fit between simulated and measured water levels and between simulated and estimated base-flow values within the study area.

Water levels were measured at 46 wells throughout the study area (fig. 9). Thirty-nine wells are observation wells with no pump, and seven wells contain pumps that provide water for a variety of uses. All observation and supply wells were constructed with a single screened interval in the Kirkwood-Cohansey aquifer system. Water-level measurements were taken at supply wells only when the pump was not running and the water level had stabilized. Water-level measure- ments were made every month from January 1995 through March 1997. Three observation wells (15-372, 15-1033, 15-1054) were instrumented with continuous (15-minute interval) water-level recorders.

Continuous and periodic measurements of streamflow were recorded at 24 streamflow-gaging stations located within the study area (fig. 13). Three streamflow-gaging stations are located on Mantua Creek, 11 on Great Egg Harbor River and its tributaries, and 10 on the Maurice River and its tributaries. Average annual base flow was estimated for 1990-95 at lowflow partial record stations and continuous record stations. An automated hydrograph-separation technique developed by Rutledge (1993) was used to separate base flow from direct runoff to determine the mean annual base flow for the period of record at two streamflow-gaging stations with continuous-record data (01411456 and 01411500). For the remaining stations, monthly base flow was estimated by using low-flow correlation equations and estimated monthly base flow for five index stations located near the study area.

\section{Water levels and base flow}

Average water levels at 46 monitored wells are presented in table 5. Averages are based on monthly measured levels at 43 wells and daily averages at 3 wells with continuous recorders. Average measured water levels during 1995-97 and 1990-95 steady-state simulated ground-water levels derived at the node of each model cell that contains a well are presented in table 5. The difference between simulated and average measured water levels was within $7 \mathrm{ft}$ at all monitored wells and in most cases was less than $5 \mathrm{ft}$. Comparison of the differences for all wells indicates a root mean square error of $3.83 \mathrm{ft}$, indicative of a reasonable fit between measured and simulated water levels. Maps of the simulated water table were compared to a map of the water table compiled from various sources dating from 1987 to 1995 (fig. 14). This comparison demonstrates that the configuration of the simulated water table corresponds favorably to that of the measured water table.

The model was calibrated by comparing the simulated base flow at each streamflow-gaging station with the mean annual base flow estimated at those stations. The differences between estimated mean annual base flow during 1990-95 and simulated steady-state annual base flow are presented in

Table 4. Hydrologic properties used in the simulation of ground-water flow, upper Maurice River Basin area, N.J.

[ft/d, foot per day; $\mathrm{ft}$, foot; $\mathrm{ft}^{2} / \mathrm{d}$, foot squared per day; na, not applicable]

\begin{tabular}{lcccccc}
\hline $\begin{array}{c}\text { Model } \\
\text { layer }\end{array}$ & $\begin{array}{c}\text { Horizontal hydraulic } \\
\text { conductivity (ft/d) }\end{array}$ & $\begin{array}{c}\text { Vertical hydraulic } \\
\text { conductivity (ft/d) }\end{array}$ & $\begin{array}{c}\text { Average thickness } \\
\text { (ft) }\end{array}$ & $\begin{array}{c}\text { Transmissivity } \\
\left.\text { (ft }{ }^{2} / \mathbf{d}\right)\end{array}$ & Storage coefficient & Specific yield \\
\hline 1 & $8-180$ & $0.8-18$ & 47.2 & $376-8,460$ & na & 0.15 \\
2 (clay) & 0.566784 & 0.056678 & 24.0 & na & na & 0.009 \\
3 & 130 & 13 & 43.7 & 5,720 & 0.15 \\
\hline
\end{tabular}




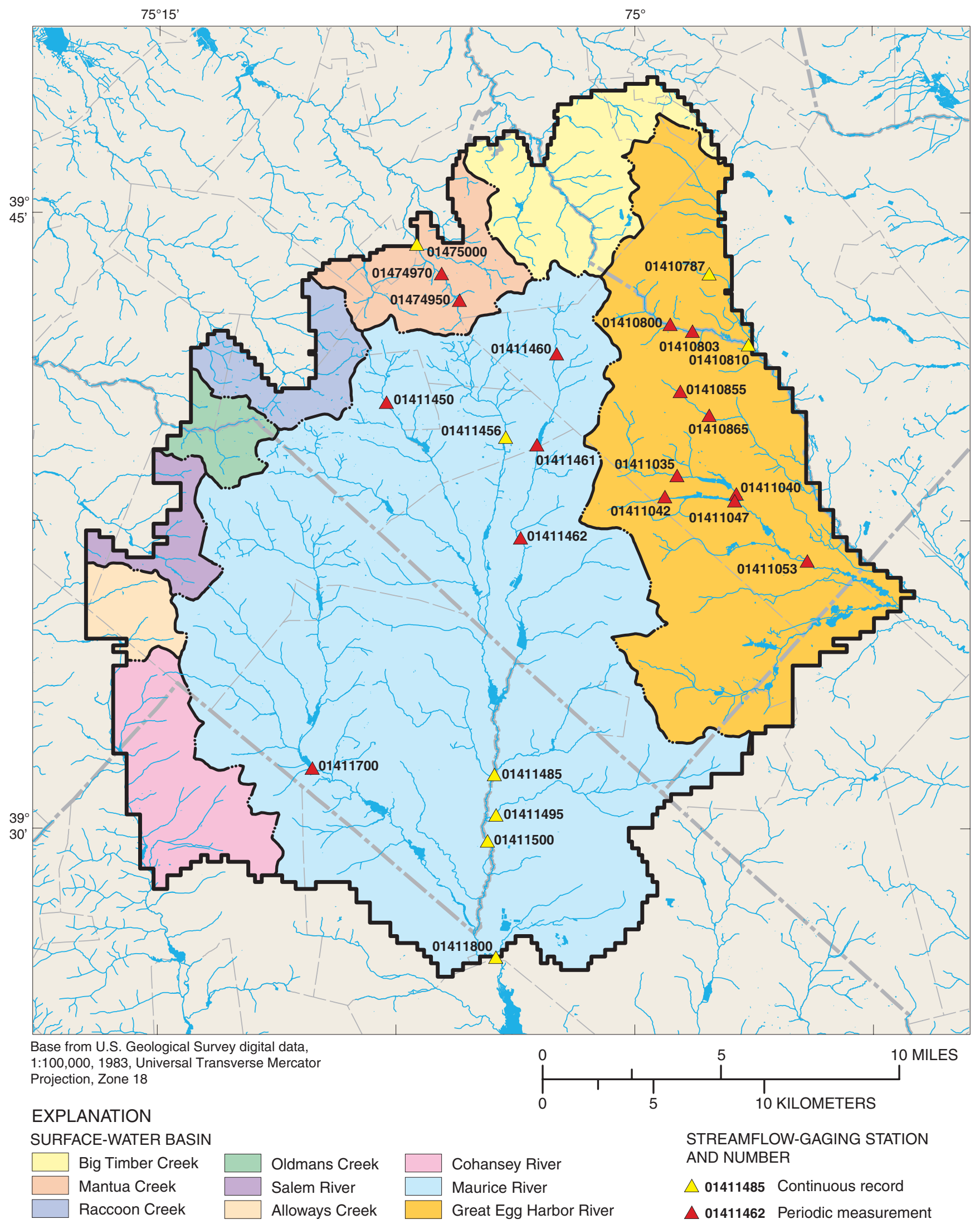

Study area boundary _ _-.. Surface-water basin boundary

Figure 13. Location of streamflow-gaging stations, upper Maurice River Basin area, N.J. 
Table 5. Simulated water levels (1990-95) and average measured water levels (1995-97) at 46 monitoring wells, upper Maurice River Basin area, N.J.

[OBS, Observation; MW, monitoring well; USGS, U.S. Geological Survey]

\begin{tabular}{|c|c|c|c|c|}
\hline $\begin{array}{c}\text { USGS } \\
\text { well } \\
\text { number }\end{array}$ & Well name & $\begin{array}{c}\text { 1990-95 simulated } \\
\text { water level } \\
\text { (feet) }\end{array}$ & $\begin{array}{c}\text { 1995-97 average } \\
\text { measured water level } \\
\text { (feet) }\end{array}$ & $\begin{array}{c}\text { Difference between } \\
\text { simulated and average } \\
\text { measured water level (feet) }\end{array}$ \\
\hline $11-692$ & RUTGERS R\&D1 SHALLOW OBS & 97.43 & 94.84 & 2.59 \\
\hline $11-694$ & RUTGERS R\&D3 DEEP OBS & 96.65 & 94.77 & 1.88 \\
\hline $11-877$ & SUNNYSIDE FARMS MW-6 & 59.48 & 63.87 & -4.39 \\
\hline $11-880$ & CHAPMAN MOBILE HOME MW-4 & 92.21 & 85.26 & 6.95 \\
\hline $11-881$ & CHAPMAN MOBILE HOME MW-1 & 95.28 & 89.49 & 5.79 \\
\hline $11-882$ & SHIELDALLOY MC SC24S & 89.31 & 83.80 & 5.51 \\
\hline $11-883$ & SHIELDALLOY MC SC24D & 88.92 & 83.34 & 5.58 \\
\hline $15-759$ & MESIANO 1 & 141.12 & 139.14 & 1.98 \\
\hline $15-763$ & MOORE 2 & 91.89 & 89.71 & 2.18 \\
\hline $15-764$ & SCAFONIS D & 116.00 & 110.25 & 5.75 \\
\hline $15-792$ & PP1 & 113.29 & 110.60 & 2.69 \\
\hline $15-793$ & FERRUCCI 10 & 99.72 & 97.18 & 2.54 \\
\hline $15-804$ & MALAGA 1 & 94.65 & 90.52 & 4.13 \\
\hline $15-810$ & ELK 1 & 132.01 & 128.80 & 3.21 \\
\hline $15-812$ & CORONA 1 & 96.63 & 95.47 & 1.16 \\
\hline $15-842$ & SA MW3 & 97.44 & 91.76 & 5.68 \\
\hline $15-1059$ & USGS TPE OBS-3 DEEP & 144.72 & 139.36 & 5.36 \\
\hline $15-1174$ & DEANS EVERGREENS 3 & 137.23 & 133.87 & 3.36 \\
\hline $15-1175$ & SHIELDALLOY MC SC14S & 97.71 & 92.43 & 5.28 \\
\hline $33-469$ & PARVIN PARK SHOP & 73.24 & 71.13 & 2.11 \\
\hline $33-677$ & UPPER PITTS SLF MW1 & 135.52 & 136.22 & -.70 \\
\hline $33-680$ & USGS COLES FARM OBS-1 & 127.49 & 128.70 & -1.21 \\
\hline $33-681$ & USGS COLES FARM OBS-2 & 127.49 & 128.73 & -1.24 \\
\hline $33-808$ & ELMER HOSP MW-3A & 113.02 & 114.37 & -1.35 \\
\hline 33-809 & ASHS MW-1 & 87.87 & 81.70 & 6.17 \\
\hline $33-810$ & ASHS MW-3 & 86.01 & 80.94 & 5.07 \\
\hline $33-811$ & ASHS MW-2 & 86.01 & 81.19 & 4.82 \\
\hline $33-812$ & HARDING WOODS MW-4 & 113.45 & 109.66 & 3.79 \\
\hline $33-813$ & ELMER HOSP MW-1A & 116.35 & 118.11 & -1.76 \\
\hline $33-814$ & N.J. BELL MW-1 & 124.55 & 129.51 & -4.96 \\
\hline $33-815$ & MONROEVILLE PS MW-1 & 126.60 & 124.96 & 1.64 \\
\hline \multirow[t]{2}{*}{$33-823$} & UPPER PITTS SLF MW2 & 133.79 & 136.77 & -3.01 \\
\hline & & & Root mean square error & 3.83 \\
\hline
\end{tabular}




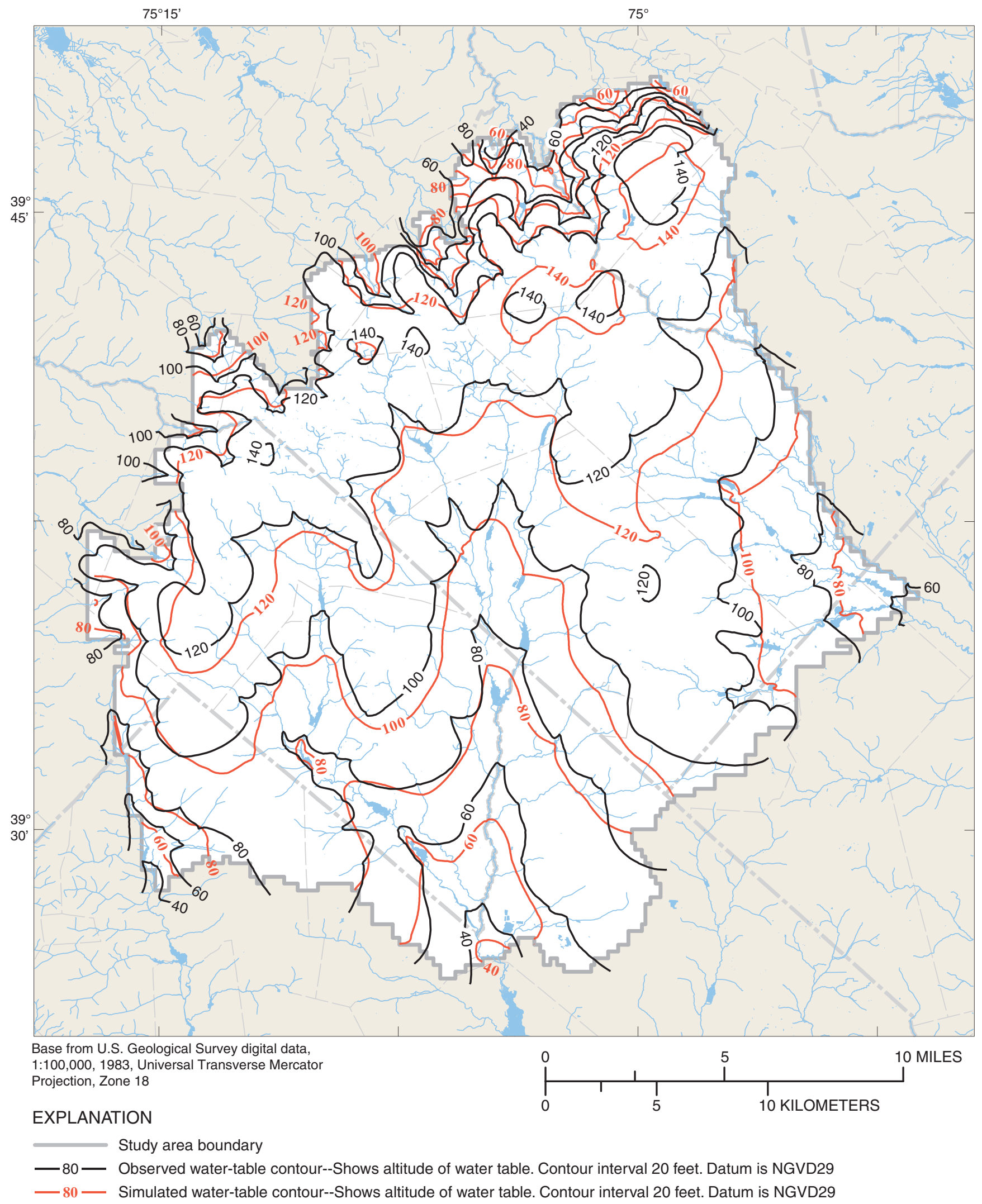

Figure 14. Composite measured and simulated 1990-95 water-table altitudes, upper Maurice River Basin area, N.J. 
figure 15 and table 6 . The differences between simulated and estimated mean annual base flow are within $3 \mathrm{ft}^{3} / \mathrm{s}$ at streamflow-gaging stations in the Great Egg Harbor River Basin, within $8 \mathrm{ft}^{3} / \mathrm{s}$ at the stations in the Maurice River Basin, and within $2.5 \mathrm{ft}^{3} / \mathrm{s}$ at Maurice River at Norma, N.J. (01411500). This station is an important calibration target because of its long period of record (1932 to present) and large drainage area. The root mean square error of the difference between simulated and estimated mean annual base flow at all streamflow-gaging stations in the study area is $3.17 \mathrm{ft}^{3} / \mathrm{s}$, indicative of a reasonable fit between simulated and estimated base flow.

\section{Sensitivity analysis}

The calibrated steady-state model is able to reasonably approximate average ground-water levels and base flows during 1990-95. It was constructed using a combination of boundary conditions, hydrologic properties, and physical geometry representing the framework through which ground water flows. Though the calibrated flow model accurately represents the physical flow system, other combinations of model parameters also may be able to match the calibration criteria within an acceptable range.

The purpose of sensitivity analysis is to quantify the uncertainty in the calibrated model due to uncertainty in the estimates of aquifer parameters, stresses, and boundary conditions (Anderson and Woessner, 1991). To evaluate the degree to which the values of certain hydrologic parameters affected the simulated water-level altitudes and base flow, model simulations were performed for a range of properties, such as horizontal hydraulic conductivity, vertical hydraulic conductivity, streambed conductance, recharge, and withdrawals. One property or stress was changed for each simulation to determine how each change affected the simulated water levels and base flow. A limited sensitivity analysis was performed by comparing the model response to variable hydrologic properties and stresses. The response of simulated water levels and base flow are compared to measured values at each calibration point in the steady-state model. The basis of comparison is the root mean square error of all calibration data for each model simulation.

Water-level altitudes are most sensitive to increases in recharge, moderately sensitive to increases in withdrawals and horizontal hydraulic conductivity, and least sensitive to increases in vertical hydraulic conductivity and streambed conductance (fig. 16a.). Water-level altitudes in the calibrated model are most sensitive to decreases in horizontal hydraulic conductivity, moderately sensitive to decreases in withdrawals and recharge, and least sensitive to decreases in streambed conductance and vertical hydraulic conductivity. A reduction in hydraulic conductivity causes the ground-water pressure head to increase.

Base flow in the calibrated model is very sensitive to both increases and reductions in recharge (fig. 16b). Comparison of the effects of varying recharge, withdrawals, horizontal hydraulic conductivity, vertical hydraulic conductivity, and

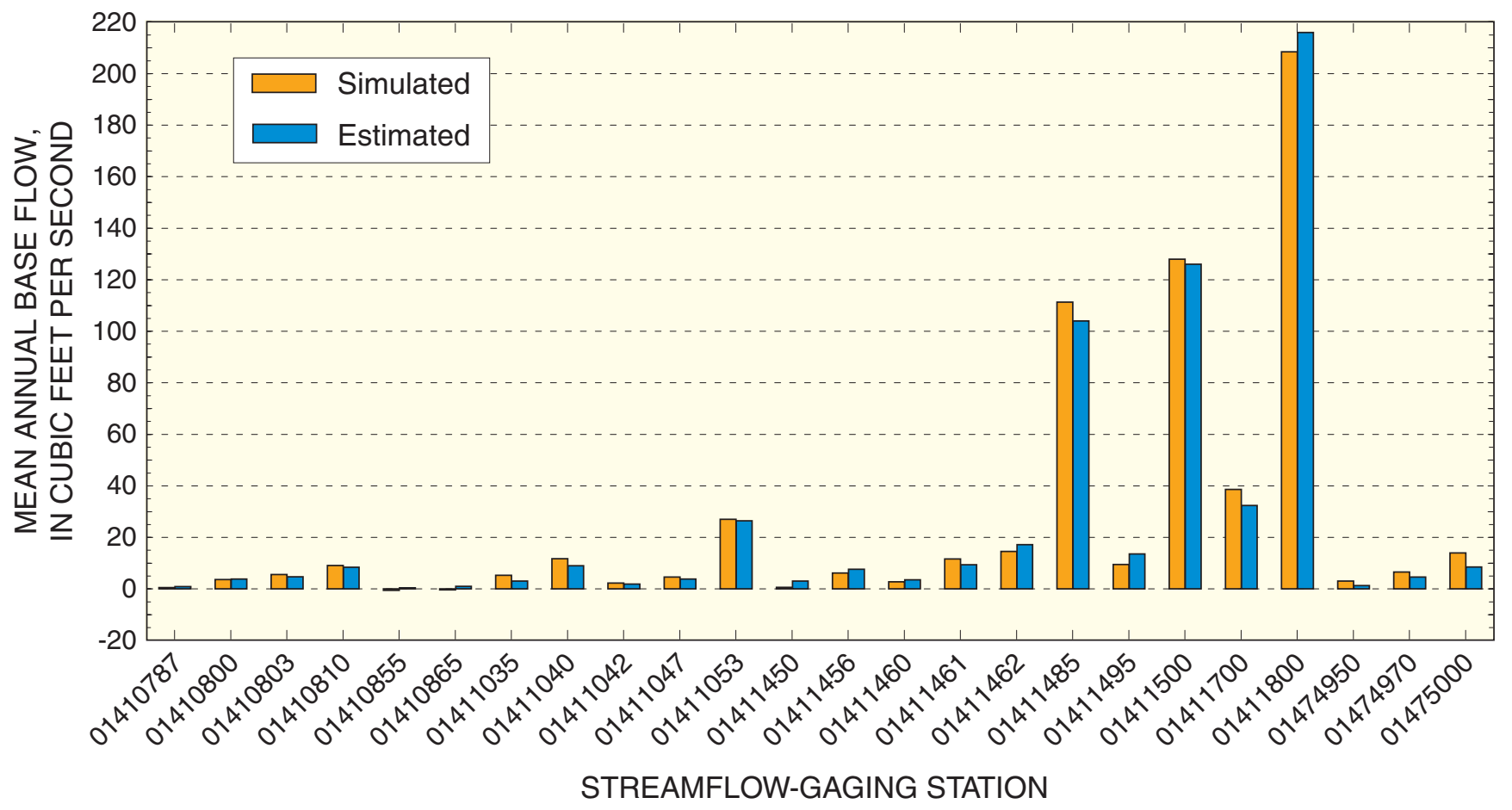

Figure 15. Estimated and simulated mean annual base flow at 24 streamflow-gaging stations, upper Maurice River Basin area, N.J., 1990-95. 
Table 6. Simulated and estimated mean annual base flow at 24 streamflow-gaging stations during 1990-95, upper Maurice River Basin area, N.J. (Locations of stations shown on figure 13.)

$\left[\mathrm{mi}^{2}\right.$, square miles; $\mathrm{ft}^{3} / \mathrm{s}$, cubic feet per second; Rd, road; Ck, Creek; BFS, base-flow separation; LFC, low-flow correlation]

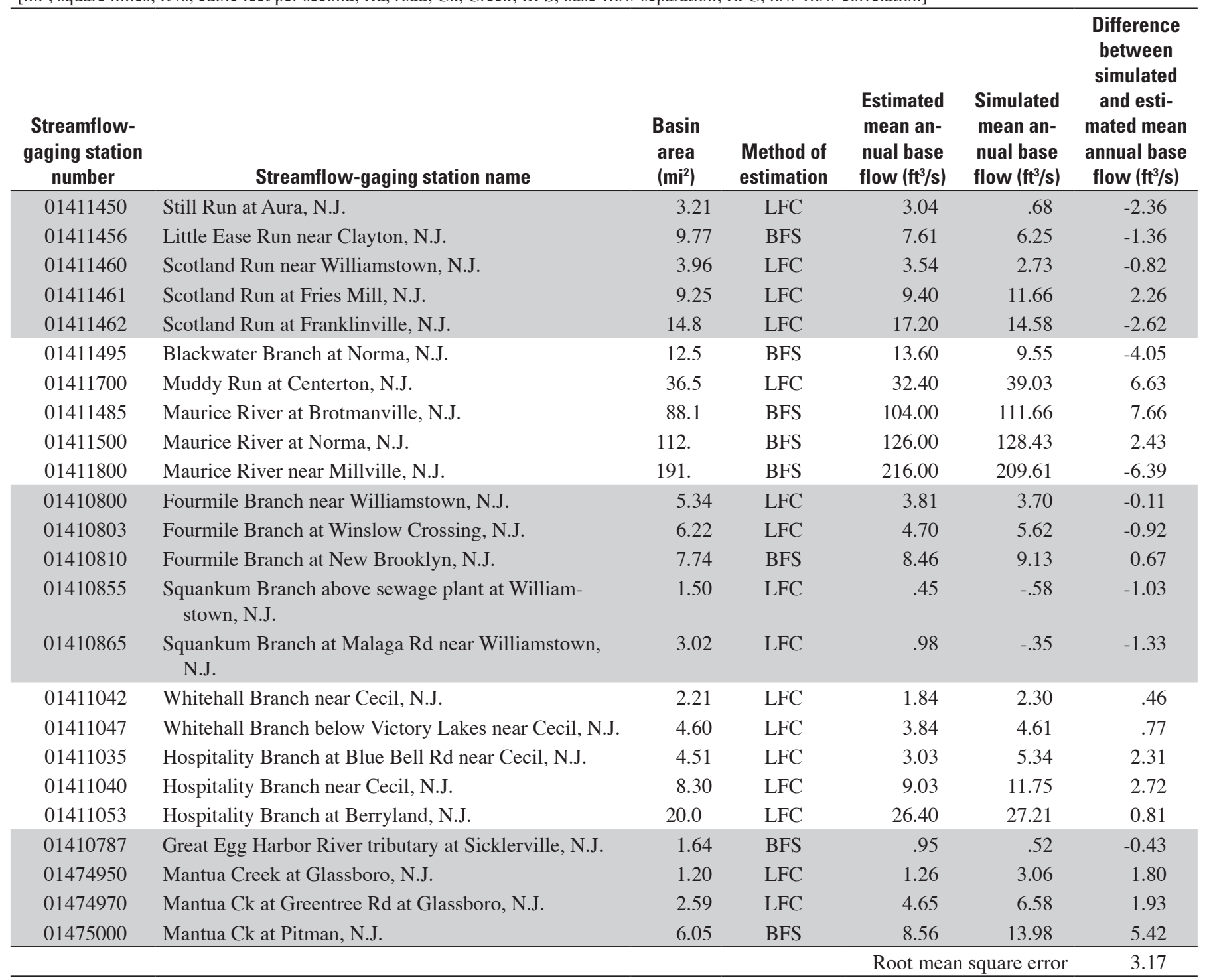

streambed conductance by the same percentage indicates that the response of simulated base flow is an order of magnitude greater for recharge than for withdrawals and the other hydrologic properties. As a result, the level of confidence in the calibrated recharge values used in model simulations is high. Simulated base flow was moderately sensitive to increasing or decreasing withdrawals and horizontal hydraulic conductivity, and least sensitive to changes in vertical hydraulic conductivity and streambed conductance (fig. 16c). Sensitivity analysis indicates that recharge is probably not significantly lower or higher, withdrawals are probably not significantly higher, and hydraulic conductivity is probably not significantly lower than the values used in the model.

\section{Transient calibration}

The ground-water flow model was calibrated to transient conditions using monthly stress periods. The transient simulation spans 39 months (January 1994 through March 1997) that are represented by 39 stress periods with 10 time steps per period that increase by a factor of 1.5 . The 27 -month period from January 1995 through March 1997 was used to calibrate the transient model. Comparisons between simulated and measured values were not made until the 13th stress period of the simulation (January 1995), allowing the model to adjust from initial conditions to variable monthly stresses. In addition, water-level measurements at most observation wells did not start until early 1995. Values of hydraulic properties determined during the steady-state calibration were used in the initial transient model. Daily estimates of recharge were totaled 

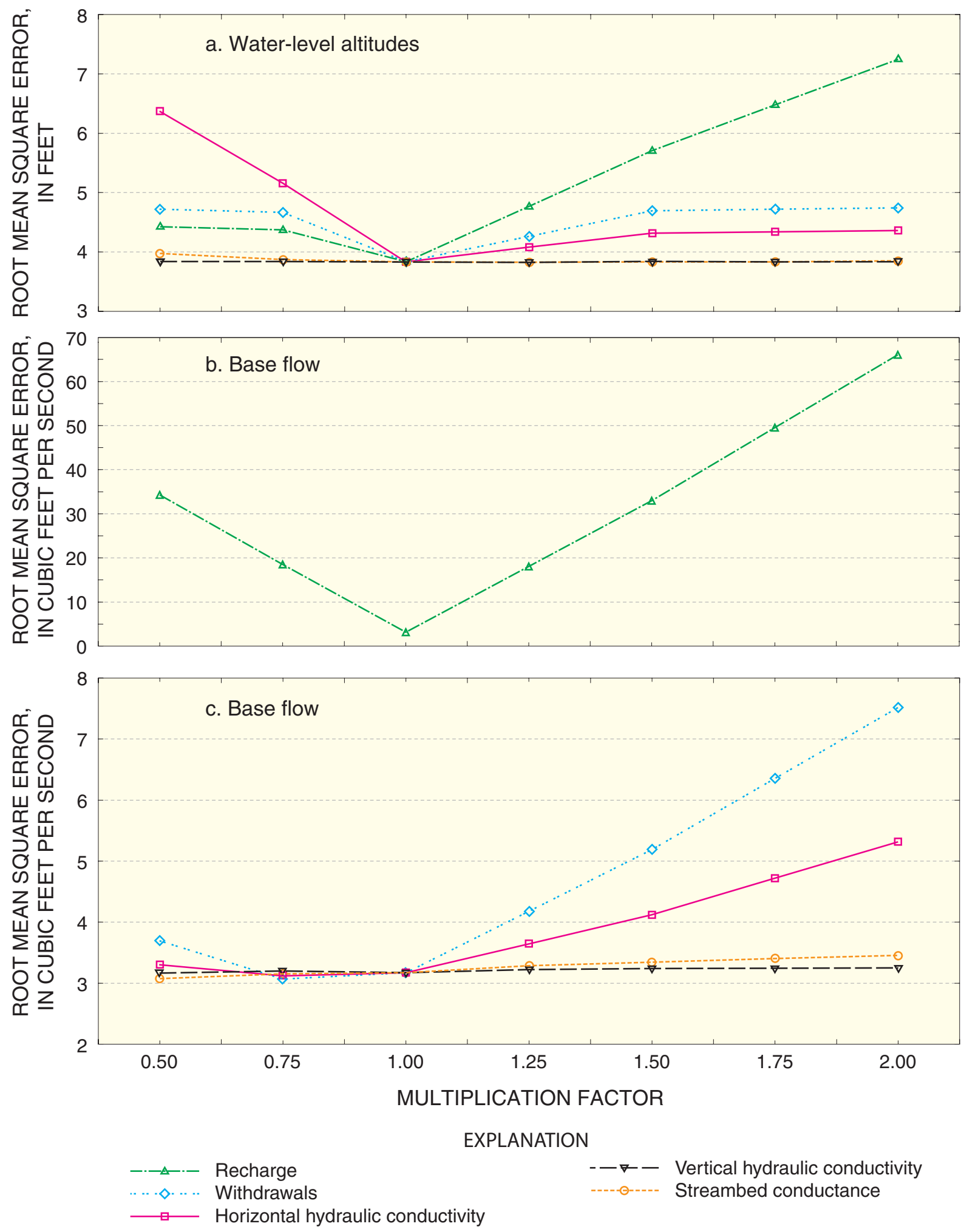

Figure 16. Sensitivity of (a) simulated water-level altitudes, and (b) and (c) simulated base flow, to variations in the values of groundwater withdrawals and hydrologic properties, upper Maurice River Basin area, N.J. 
by month and entered into the transient model to account for the monthly variability of this parameter. The following section describes how these values were derived.

Results of the transient calibration were evaluated by comparing water-table altitudes and base flow. Simulated water-table altitudes were compared to monthly altitudes measured at 46 observation wells in the study area. Simulated monthly base flow was compared to estimates of monthly base flow at eight streamflow-gaging stations in the Maurice River Basin. A trial-and-error approach was used and hydrologic parameters were adjusted until a reasonable match between simulated and measured water levels, and simulated and estimated base flow, was obtained.

\section{Recharge}

Published recharge rates for the unconfined KirkwoodCohansey aquifer system in the Maurice River Basin and surrounding basins are annual values (see discussion in "Hydrogeologic Framework and Ground-Water Flow"). Recharge rates are a function of and response to climatic conditions that vary daily. Although average annual recharge rates are adequate for steady-state conditions, the transient model uses monthly stress periods to examine seasonal effects on water levels and base flow. To determine monthly recharge for January 1994 through March 1997, a modified water-budget approach was used. The method applied in this study is based on the approach used for the Toms River Basin (Nicholson and Watt, 1997). Nicholson and Watt (1997) describe this approach in detail, but it is summarized here for completeness and because the approach was altered slightly.

The land-surface water budget for determining recharge takes the following form when expressed as an equation.

$$
R=P-Q_{\mathrm{dr}}-E T-\Delta S M
$$

where,

$$
\begin{aligned}
R & =\text { recharge } \\
P & =\text { precipitation }, \\
Q_{\mathrm{dr}} & =\text { direct runoff } \\
E T & =\text { evapotranspiration, and } \\
\Delta S M & =\text { change in soil moisture storage. }
\end{aligned}
$$

(All variables are expressed in inches.)

A soil-moisture deficit will occur if the amount of moisture in the soil is less than its storage capacity. Recharge occurs from a precipitation event only when this deficit is overcome. If recharge rates are calculated in monthly increments, the sum of monthly evapotranspiration and the deficit in soil moisture could exceed total monthly precipitation, indicating that there was no recharge during the month. Yet, when evaluated on a daily basis, some precipitation may break through the soil zone during days of the month that have significant storms. Calculating recharge on a monthly basis could underestimate recharge rates, especially during the sum- mer. It is necessary to estimate recharge daily to account for individual storms and possible recharge during months when evapotranspiration and the deficit in soil moisture are high. Calculated daily recharge was totaled for each month of the transient simulation. A maximum soil-moisture deficit of 1.5 inches was assumed in the calculations. In order to account for the soil-moisture deficit the water budget was modified and is expressed by the following equation.

$$
R_{m}=\left[\left[\sum_{n=1}^{d(m)} P_{(m, n)}-E T_{(m, n)}-\operatorname{SMD}(m, n-1)\right]-Q_{d r(m)}\right]
$$

where,

$$
\begin{aligned}
R_{m} & =\text { recharge for month } \mathrm{m}, \\
d_{(m)} & =\text { number of days in month } \mathrm{m}, \\
P_{(m, n)} & =\text { precipitation on day } \mathrm{n} \text { in month } \mathrm{m}, \\
E T_{(m, n)} & =\text { evapotranspiration on day } \mathrm{n} \text { in month } \mathrm{m}, \\
S M D_{(m, n-1)} & =\text { soil-moisture deficit from the day preceding } \\
Q_{d r(m)} & \quad \text { day } \mathrm{n} \text { in month m, and }
\end{aligned}
$$

(All variables except $d_{(m)}$ are expressed in inches.)

Comparison of daily precipitation and water-level response at well 15-1054 near the Glassboro, N.J., precipitation station indicated virtually no time delay in recharge passing through the unsaturated zone to the water table (fig. 17). As a result, the method applied by Nicholson and Watt (1997) was used, but recharge rates were not offset in time. A comparison of total monthly recharge with monthly precipitation for January 1994-March 1997 indicates a significant decrease in recharge in the second half of 1994 through the summer of 1995 and a period of high recharge from the fall of 1995 through March 1997 (fig. 18). Superimposed on this trend is the seasonal pattern of higher recharge during winter and spring, and lower recharge during summer and fall.

\section{Water levels and base flow}

Transient simulations were evaluated by comparing simulated and measured monthly water-level altitudes in 46 observation wells. Measured and simulated water levels at eight spatially distributed wells in the Maurice River Basin are presented in table 7. Comparisons of water-level fluctuations were made on monthly values from January 1995 through March 1997. The difference between simulated and measured water-level fluctuations ranged from -1.34 to $2.16 \mathrm{ft}$ at these wells, with a mean difference of $0.88 \mathrm{ft}$, indicative of a reasonable fit. Hydrographs for these wells demonstrate seasonal trends in, and the relative correlation between, simulated and measured water levels (fig. 19).

Streamflow-gaging stations were selected as calibration points on the basis of integrating flow from a distinct area of the Maurice River Basin, and(or) having a long period of record. Base-flow separations and low-flow correlations were 


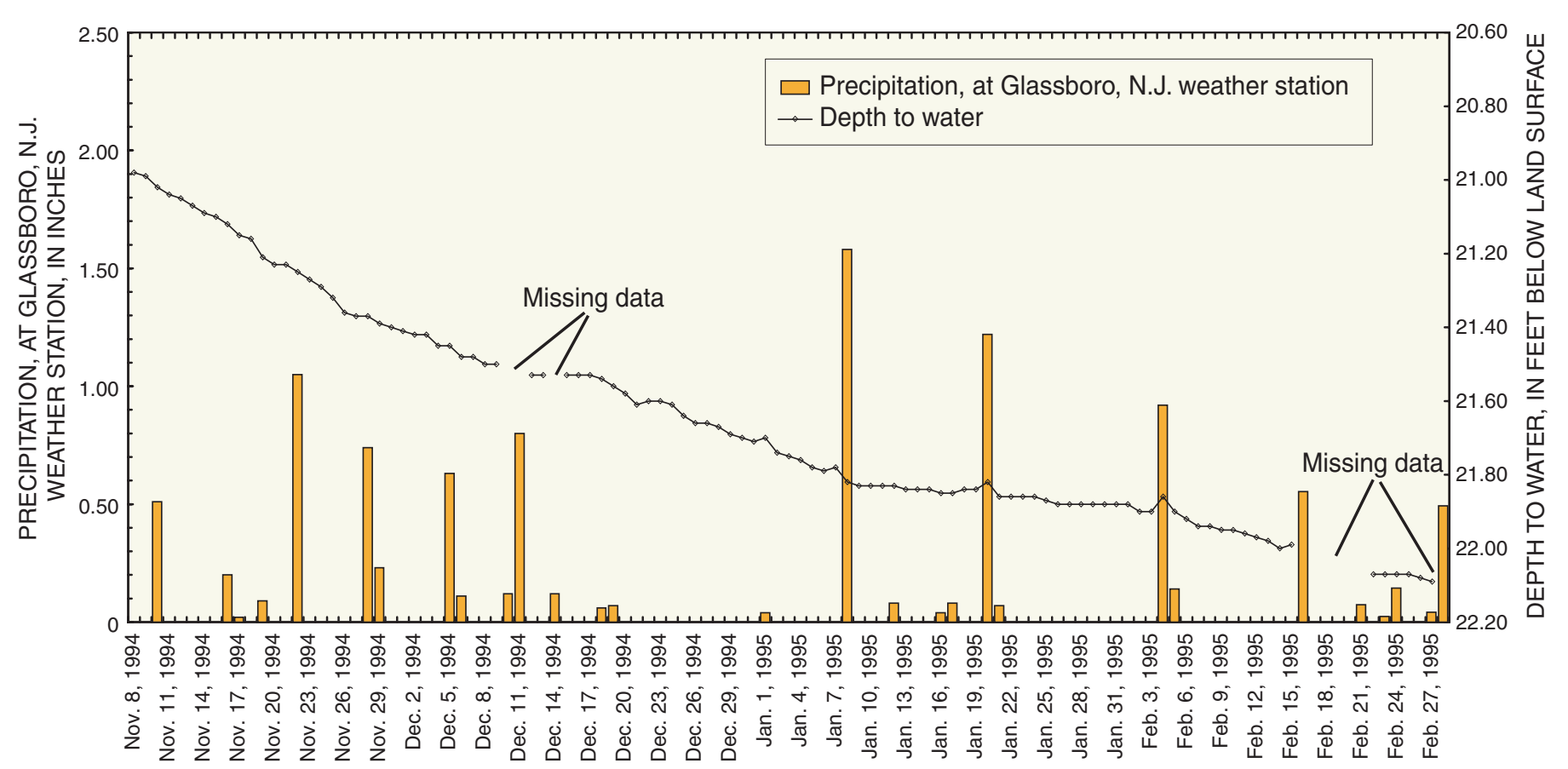

Figure 17. Daily precipitation recorded at Glassboro, N.J., weather station and water-level altitudes in well 15-1054, November 8, 1994 to February 28, 1995.

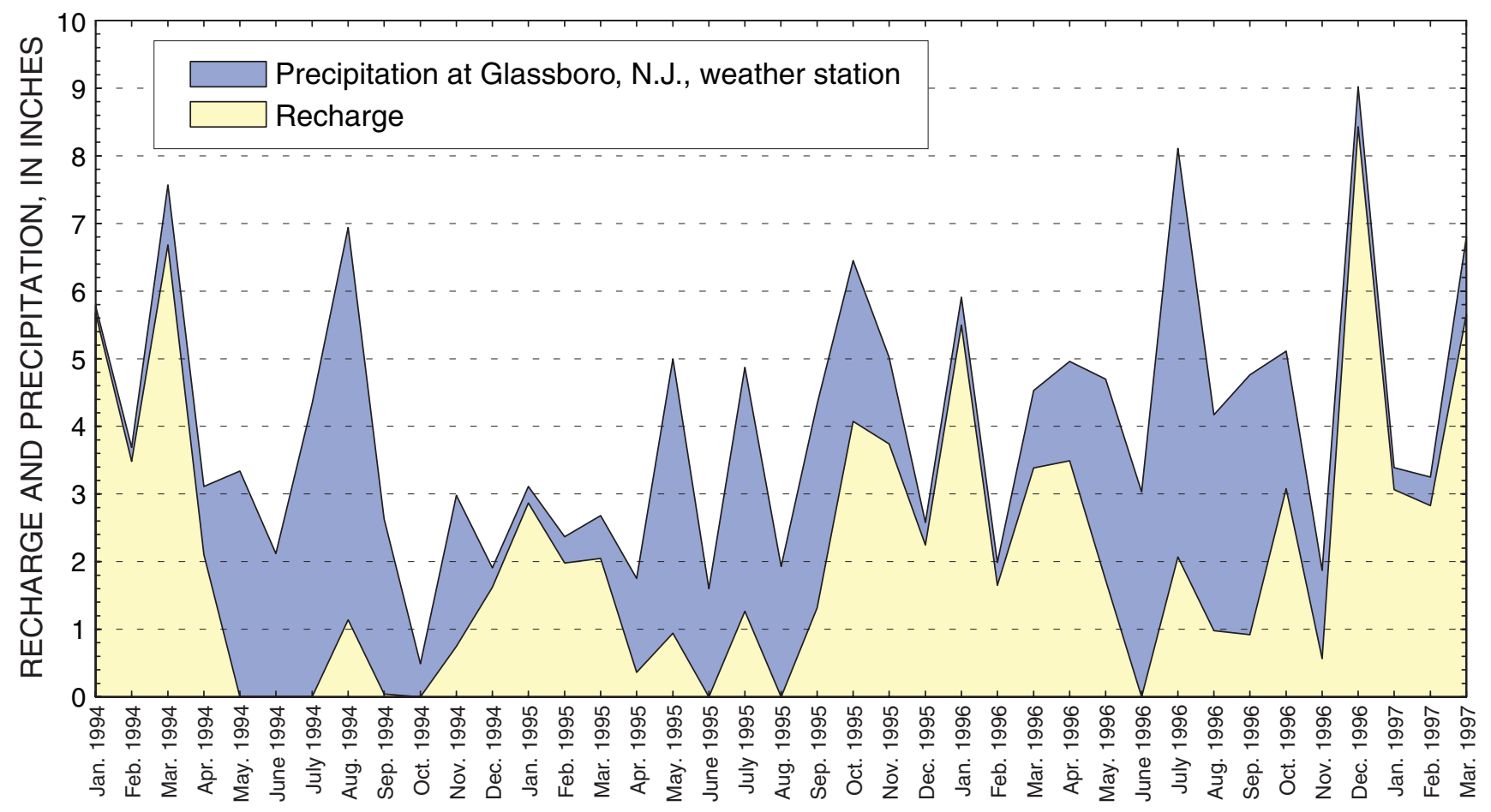

Figure 18. Monthly precipitation recorded at Glassboro, N.J., weather station and estimated monthly recharge, January 1994 through March 1997. 
Table 7. Simulated and measured water-level fluctuations at eight observation wells during 1995-97, upper Maurice River Basin area, N.J.

[USGS, U.S. Geological Survey; ft, feet]

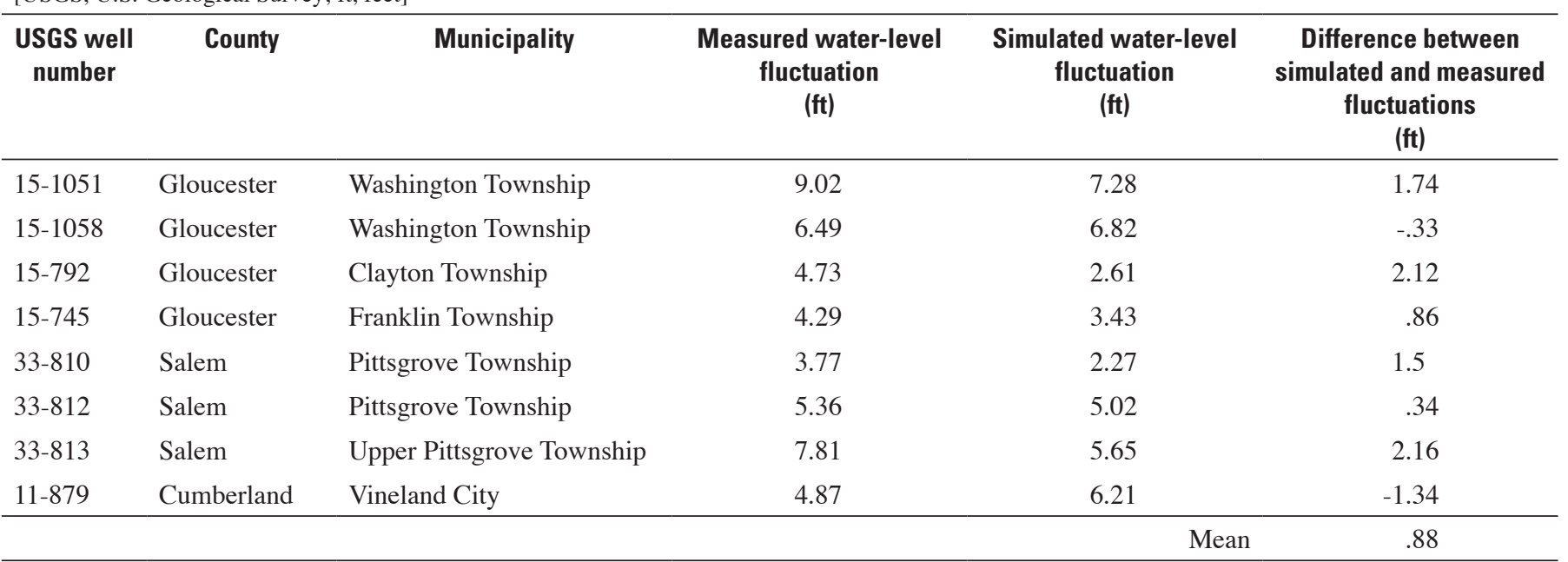
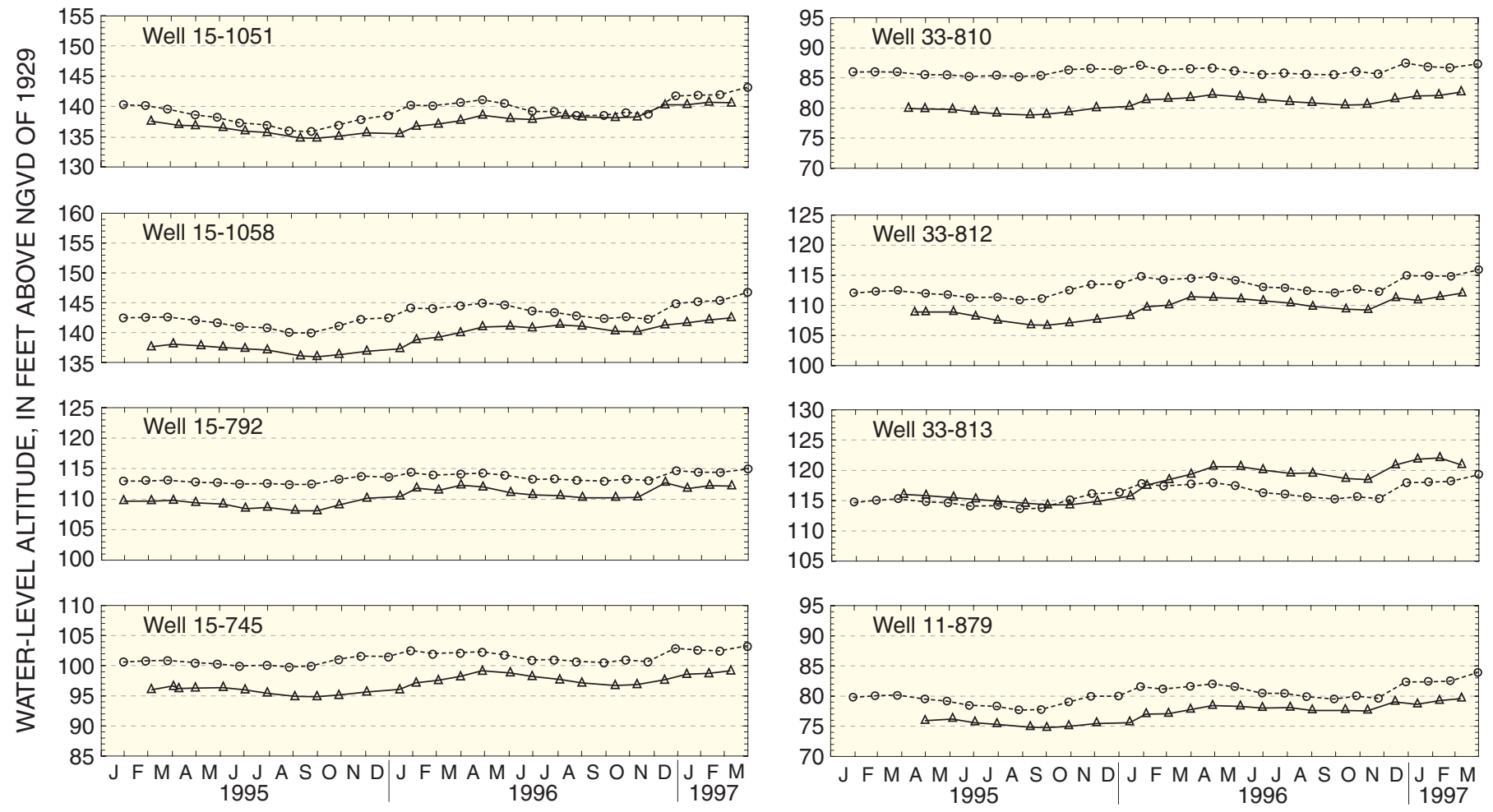

\section{EXPLANATION \\ $\triangle$ Measured \\ --๑--. Simulated}

Figure 19. Measured and simulated monthly water-level altitudes at selected observation wells in the upper Maurice River Basin area, N.J., January 1995 through March 1997. 
Table 8. Simulated and estimated mean monthly base flow at Maurice River streamflow-gaging stations, N.J., for January 1995-March 1997.

[HS, hydrograph separation; LFC, low-flow correlation, $\mathrm{ft}^{3} / \mathrm{s}$, cubic feet per second]

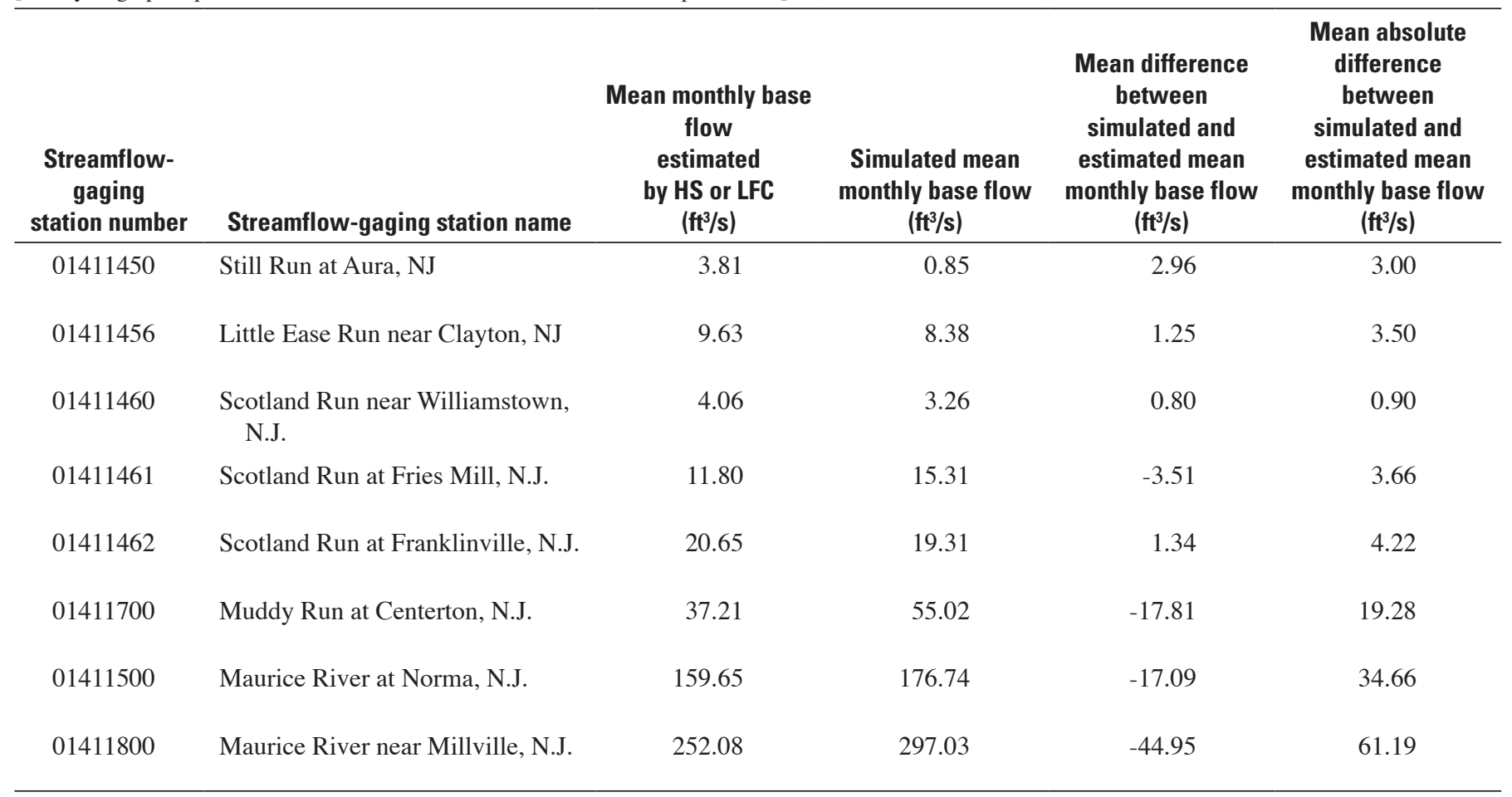

used to estimate average monthly base flow over a 27 -month period at three continuous-record stations and five low-flow partial-record stations. Estimated monthly base flow was compared to simulated monthly base flow at the stations listed in table 8. Monthly simulated and estimated base flows at selected streamflow-gaging stations in the Maurice River Basin are presented in figure 20 for January 1994 through March 1997.

Statistics that summarize the match between simulated and estimated monthly base flow at eight streamflow-gaging stations in the Maurice River Basin are listed in table 8. The mean difference between simulated and estimated mean monthly base flow during the calibration period is $0.80 \mathrm{ft}^{3} / \mathrm{s}$, near the northern end of Scotland Run $(01411460$, Scotland Run near Williamstown, N.J.) and $44.95 \mathrm{ft}^{3} / \mathrm{s}$ at the southern boundary of the Upper Maurice River Basin area ( 01411800, Maurice River near Millville, N.J.). Mean differences are generally small when compared to mean monthly base flows at streamflow-gaging stations in the Maurice River Basin. Larger differences occur at 01411450 (Still Run at Aura, N.J.), which integrates flow from a very small part of the basin, and at 01411700 (Muddy Run at Centerton, N.J.), which may be affected by in-stream agricultural withdrawals that are not accounted for in the streamflow records. Residual values are small at stations on the Maurice River, which indicates that bias in simulated mean monthly base flow is small. The range in simulated base flow at all stations, except on Muddy Run, closely matches the estimated range over the same period of time, indicating that the transient model simulates groundwater flow to the stream reasonably well.

\section{Sensitivity analysis}

A transient sensitivity analysis was conducted by performing multiple ground-water model simulations. Each simulation represents a modification of the calibrated transient model, achieved by changing the numeric value of only one hydrologic property per model simulation. The value of a specific hydrologic property was either doubled or decreased by 50 percent from the calibrated value in separate simulations. Properties analyzed include horizontal hydraulic conductivity, vertical hydraulic conductivity, storage coefficient, streambed conductance, and recharge. Streambed conductance values were either increased by a factor of ten or decreased by a factor of 0.1 in separate model simulations. Results are compared at all calibration sites for a stress period with low recharge rates (October 1994) and high recharge rates (March 1997). The effect of these changes on water-level altitudes is shown in figure 21a. Water-level altitudes are sensitive to increases and decreases in all properties, although least sensitive to decreases in vertical hydraulic conductivity and increases in streambed conductance. Water-level altitudes are moderately sensitive to both increases and decreases in horizontal hydraulic conductivity, increases and decreases in storage coefficient, 

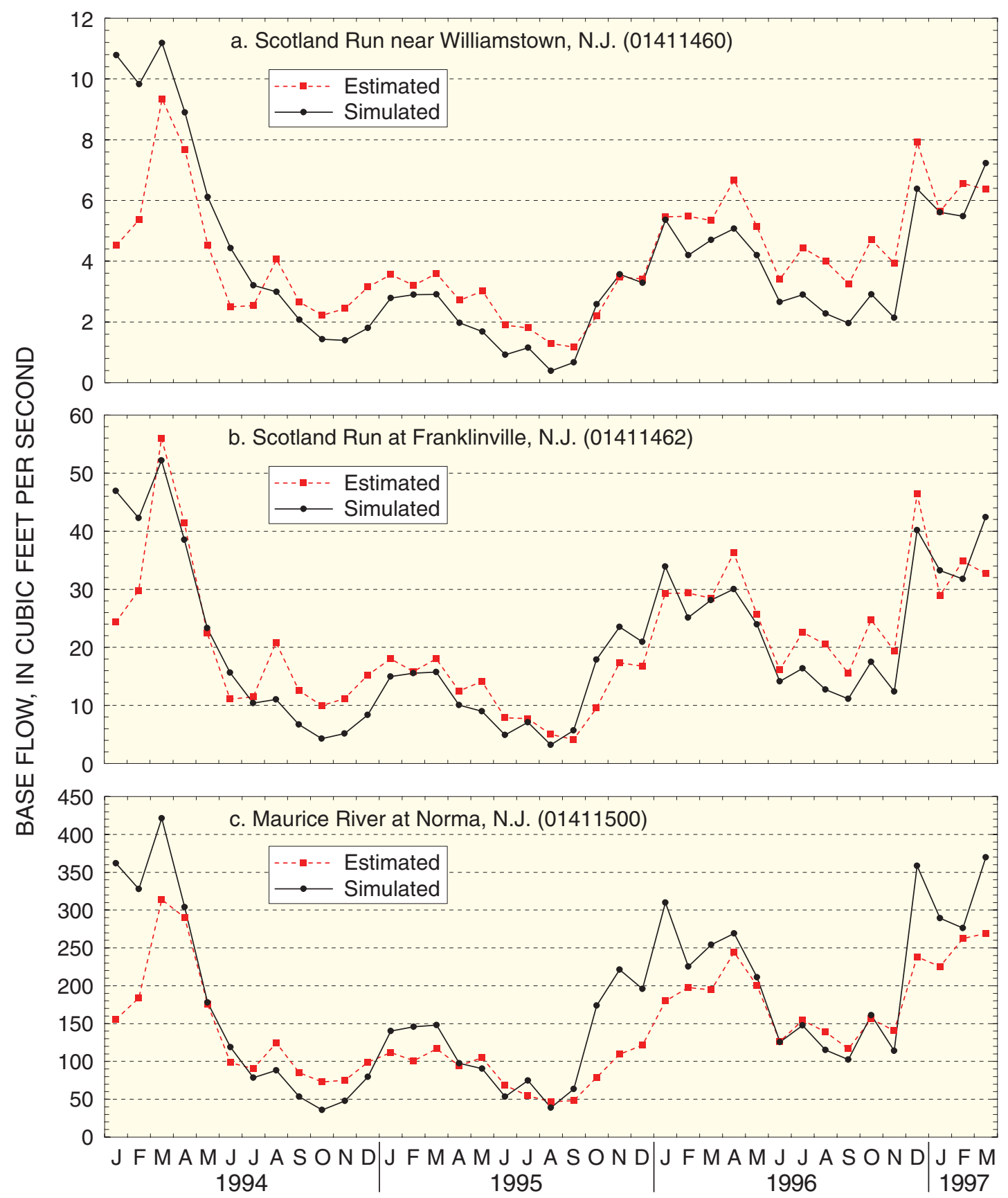

Figure 20. Estimated and simulated monthly base flow at streamflow-gaging stations (a) Scotland Run near Williamstown, N.J. (014111460); (b) Scotland Run at Franklinville, N.J. (01411462); and (c) Maurice River at Norma, N.J. (01411500), January 1994 through March 1997. 

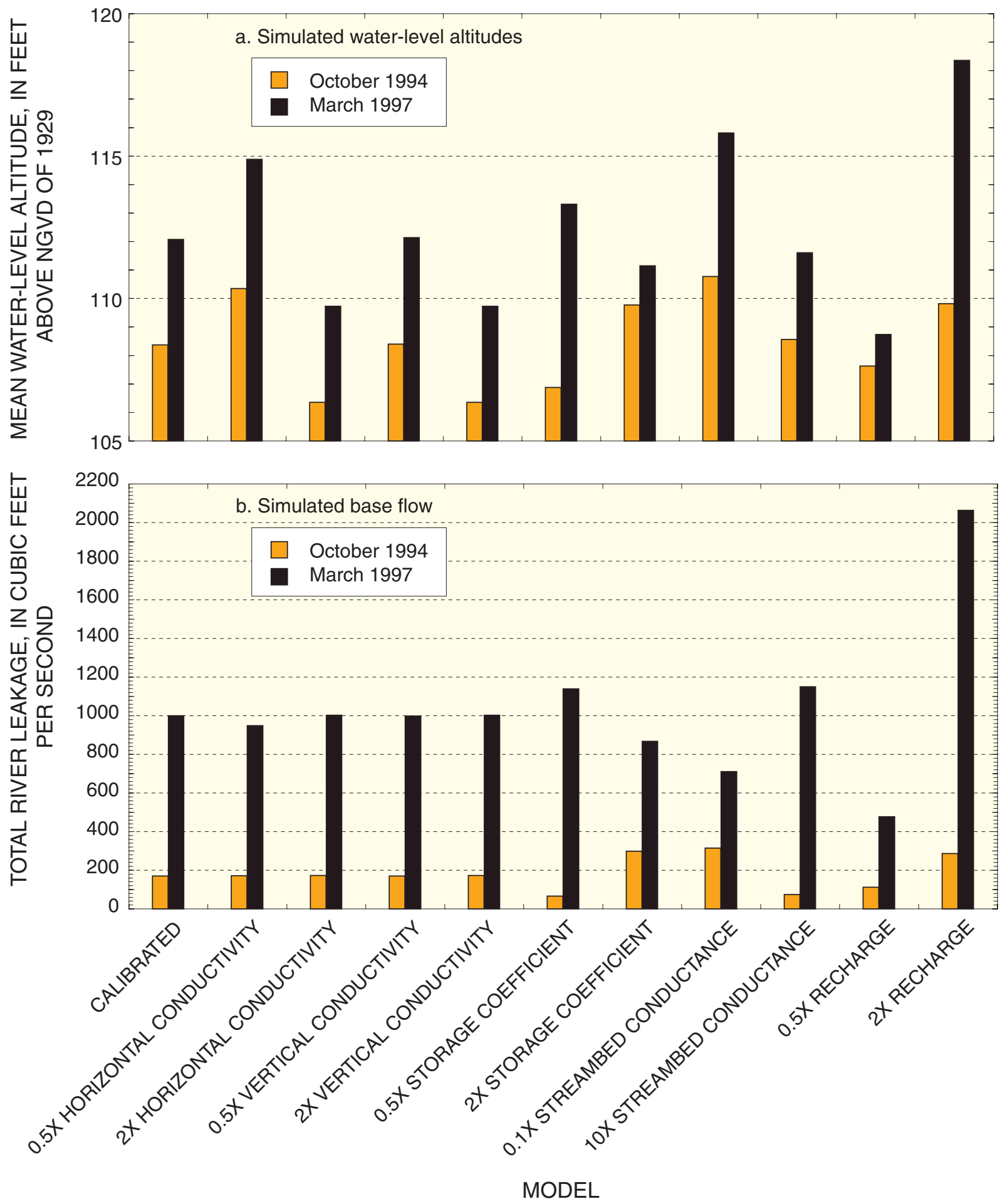

Figure 21. Relation of (a) simulated water-level altitudes and (b) simulated base flow to variations in the values of hydrologic properties during October 1994 and March 1997, upper Maurice River Basin area, N.J. 
and increases in the vertical conductivity. Transient waterlevel altitudes are most sensitive to increases and decreases in recharge and decreases in streambed conductance. Transient response of base flow is largely insensitive to increases or decreases in horizontal hydraulic conductivity and vertical hydraulic conductivity (fig. 21b.), moderately sensitive to changes in the storage coefficient and streambed conductance, and most sensitive to increases or decreases in recharge.

\section{Model Limitations}

A ground-water flow model is by design an approximate representation of an actual ground-water flow system. The ground-water flow models developed in this study are simplified, large-scale representations of the heterogeneous unconfined Kirkwood-Cohansey aquifer system. The models can be used by water purveyors and regulators to help estimate the response of the ground-water system to various stress regimes. In this study, the accuracy of the simulated ground-water levels and flows is limited by the accuracy with which the actual ground-water flow system is represented by the zones of hydraulic conductivity, the model grid and cell size, and the bottom no-flow boundary condition.

The horizontal hydraulic conductivity of each model layer was divided into several zones based on the predominant lithology of a given area at a specific depth. These zones were identified by examining existing well logs and were assigned a representative conductivity. Conductivities were modified during calibration on the basis of a comparison between simulated and measured water levels. The calibrated values of hydraulic conductivity result in a good match between simulated and measured water levels at the existing observation wells; however, they do not represent the local-scale heterogeneity of the Kirkwood-Cohansey aquifer system between well-log and observation-well locations.

The models were discretized using a variably spaced grid with the smallest model cells ( $250 \mathrm{ft}$ by $500 \mathrm{ft}$ ) along the main stem of the Maurice River. The main purpose of the discretization scheme was to accurately represent ground-water flow to the Maurice River, however, model cells near the edge of the grid, farther from the area of interest, are $2,000 \mathrm{ft}$ by $1,000 \mathrm{ft}$ in size and simulate stresses, such as production wells, on the ground-water flow system in that area with less precision than do the smaller cells near the river.

The bottoms of the flow models are coincident with a basal clay unit in the Kirkwood Formation and were defined as no-flow boundaries. In the Kirkwood-Cohansey aquifer system, flow across this boundary occurs as leakage to the deeper confined aquifers. Leakage was estimated to be zero in the models because the permeability of the basal clay and flow rate through this unit are low. Therefore, simulated water levels may show a greater response to recharge than water levels in the actual system, where some ground water flows through the confining unit to greater depths.
The transient ground-water flow model is considered to be an accurate representation of the complex physical groundwater flow system in the Kirkwood-Cohansey aquifer for the time and area included in the model calibration. The transient model is calibrated to a 2-year, 3-month period using climatic conditions from January 1995 to March 1997. Uncertainty will be greater for results of simulations that use different climatic conditions for a different time period or simulations of a different duration. Also, the calibration was achieved using estimated base flow and measured water levels at sites primarily within the upper Maurice River Basin. The model includes portions of several adjoining surface-water basins but, because calibration data for this area are limited, simulation results are less accurate in the adjoining basins.

\section{Simulations of Pre- and Post- Development Conditions}

The calibrated steady-state and transient models were used to estimate natural hydrologic conditions prior to the widespread utilization of ground water in this area. The simulation of conditions prior to human-induced ground-water withdrawals are referred to as predevelopment conditions. The transient ground-water flow model also was used to simulate post-development conditions for the years 1994-97. Comparison of pre- and post-development simulations demonstrates the response of the Kirkwood-Cohansey aquifer system to present-day stresses.

\section{Predevelopment conditions}

Before development occurred in southern New Jersey, the hydrologic system was governed by natural rates of recharge to and discharge from the ground-water flow system. To evaluate the ground-water-flow system prior to development, the effects of development were removed from the calibrated steady-state flow model. Effects of development include withdrawals from, and reduced recharge to, the ground-water system. Urbanization creates impermeable land cover such as buildings and paved surfaces that reduce the amount of recharge and increase the amount of surface runoff from precipitation. The effects of development stresses were removed from the predevelopment simulation by increasing the recharge rate and removing all ground-water withdrawals from the model simulation. Examination of the steady-state water table indicates average ground-water levels and flow directions at that time.

To estimate recharge rates that represent the natural system, urban land in the study area was identified by using 1986 land-use/land-cover data. Urban land accounts for 6 percent of the area in the Cohansey River Basin, 22.5 percent in the Maurice River Basin, 22.8 percent in the Great Egg Harbor Basin, and 50.2 percent in the Big Timber Creek Basin 
part of the study area. Recharge rates per basin were increased by 10 percent for that part of urban land in each surface-water basin. The combined effect of approximating the natural rate of recharge and removing ground-water withdrawals is illustrated by the vertical flow direction at the base of layer 1 (fig. 22). Model cells where flow is downward into layer 2 indicate recharge from layer 1 to layer 2, occurring primarily in interstream areas. Cells where vertical flow is upward from layer 2 to layer 1 correspond to stream and wetland areas.

A transient simulation of predevelopment conditions was performed to examine the effect of seasonal rates of recharge on base flow. Predevelopment conditions during several seasonal cycles were simulated by using a monthly recharge time series calculated from recent climatic and hydrologic data and using the hydrologic properties and boundary conditions of the steady-state model and storage coefficients of the transient model. Ground-water withdrawals were removed from the transient predevelopment model to examine the effect the natural climatic conditions would have on base flow in the Maurice River Basin. Simulated monthly base flows indicate the seasonal effects of climatic control on recharge rates. Comparison of results of the transient predevelopment simulation with that of the transient post-development simulation indicates the extent to which recent ground-water withdrawals affect predevelopment base flow. Results of this comparison are presented in the next section.

\section{Post-development conditions}

Population growth in southern New Jersey from 1950 to 2000 and the concomitant use of ground water as a source of freshwater has affected the ground-water-flow system in the study area. Ground-water withdrawals reduce the groundwater flow through the aquifer and decrease the amount of base flow to streams. To quantify the recent stress on the local flow system, a transient simulation of 1994-97 conditions was performed. This simulation used reported ground-water withdrawals during this time span. Comparison of results of the predevelopment and post-development transient simulations indicates the location and magnitude of base-flow reduction resulting from ground-water withdrawals.

In the upper part of the Maurice River Basin, simulated base flow decreased by as much as 62 percent at Scotland Run near Williamstown, N.J. (01411460), in August 1995 during an extended dry period and by 28 percent in September 1996 during a year with above-average precipitation (fig. 23). Simulated base flow at Scotland Run at Franklinville, N.J. (01411462), declined by 25 percent in August 1995 when compared with predevelopment conditions. Agricultural well withdrawals have reduced base flow at Muddy Run at Centerton, N.J. (01411700), by 38 percent in August 1995. Simulated base-flow reduction is 26 percent during August 1995 at Maurice River at Norma, N.J. (01411500), and 15 percent during September 1996.

\section{Simulations of Additional Ground- Water Withdrawals}

The calibrated transient model was used to simulate additional ground-water withdrawals based on projected water demands for 1995 through 2041 and maximum allocation water withdrawals during 1994-97. Withdrawals from three hypothetical public-supply wells located on a recharge boundary or adjacent to a discharge boundary were simulated. The objective of all simulations was to estimate the effects of ground-water withdrawals on base flow in the Maurice River.

\section{Projected water demands}

In 1996, the NJDEP published a planning document titled "Water for the 21st century: The vital resource-New Jersey statewide water supply plan". Data compiled in conjunction with the New Jersey statewide water supply master plan includes projected water use for every municipality in New Jersey (Robert Kecskes, N. J. Department of Environmental Protection, written commun., 1999). The NJDEP enumerated water demand for the years 1995, 2000, 2005, 2010, 2020, 2030, and 2040 for each municipality in the State. Water-use projections within a municipality were broken down further by type of use. The type of use corresponds to the water-allocation permit series and includes purveyor-supplied (public supply), and self-supplied industrial, agricultural, and residential use. To use this data in a ground-water flow simulation, projected ground-water withdrawals were divided equally between wells belonging to the same allocation series and located within the same municipality. The magnitude of reported and projected withdrawals are listed in table 9. Ground-water withdrawal data were incorporated in a transient simulation spanning the 47-year period of 1995 through 2041.

The simulation was divided into monthly stress periods with 10 time steps per stress period. Recharge values estimated for 1995-97 were used for 2009-11 and 2039-41. The goal of this simulation was to compare the effect of the projected withdrawals on base flow in the Maurice River for the years of 2010-11 and 2040-41. The years 2010 and 2040 were simulated as relatively dry years by using 1995 recharge rates (below average recharge) and the years 2011 and 2041 as relatively wet years by using 1996 recharge rates (above average recharge).

Simulated base flow at Scotland Run near Williamstown, N.J. (01411460), decreases during the spring and summer of 2010 to zero in September 2010. Base flow increases the following month and then exhibits a typical seasonal pattern, increasing in fall, winter, and early spring and decreasing in the summer (fig. 24a). During 2011, base flow reaches a minimum of 1.28 cubic feet per second $\left(\mathrm{ft}^{3} / \mathrm{s}\right)$ in September. Farther downstream at Scotland Run at Fries Mill, N.J. (01411461), and Scotland Run at Franklinville, N.J. (01411462), the seasonal pattern of base flow is similar, but the volumetric flow is 


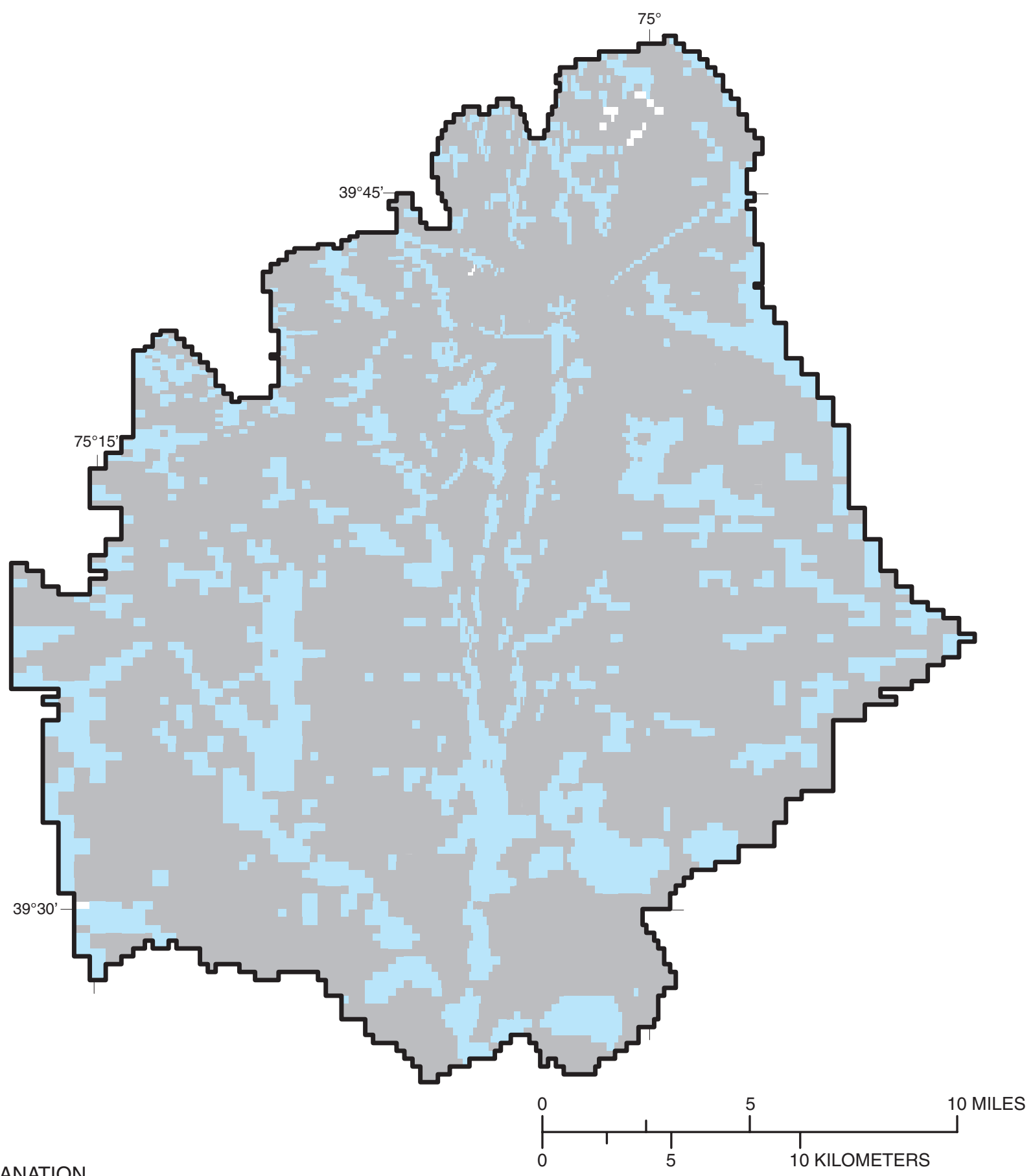

\section{EXPLANATION}

\section{RECHARGE}

Downward flow from layer 1 to layer 2

No vertical flow between layer 1 and 2

Upward flow from layer 2 to layer 1

Study area boundary

Figure 22. Vertical flow direction between model layers 1 and 2 during steady-state predevelopment conditions, upper Maurice River Basin area, N.J. 
Table 9. Reported 1995, and projected 2010 and 2040 ground-water withdrawals, upper Maurice River Basin area, N.J.

[Small differences in totals are caused by independent rounding; Mgal/yr, million gallons per year]

\begin{tabular}{|c|c|c|c|c|c|}
\hline $\begin{array}{l}\text { Water use (allocation permit } \\
\text { series) }\end{array}$ & $\begin{array}{c}1995 \text { reported } \\
\text { withdrawals } \\
\text { (Mgal/yr) }\end{array}$ & $\begin{array}{c}2010 \text { projected } \\
\text { withdrawals } \\
\text { (Mgal/yr) }\end{array}$ & $\begin{array}{c}\text { Increase over } \\
1995 \text { reported } \\
\text { withdrawal (times) }\end{array}$ & $\begin{array}{c}2040 \text { projected } \\
\text { withdrawals } \\
\text { (Mgal/yr) }\end{array}$ & $\begin{array}{l}\text { Increase over } 1995 \\
\text { reported withdraw- } \\
\text { als (times) }\end{array}$ \\
\hline Public Supply $(5,000)$ & $5,358.7$ & $7,080.81$ & 1.32 & $9,404.37$ & 1.76 \\
\hline $\begin{array}{l}\text { Agricultural (Agricultural } \\
\text { certifications) }\end{array}$ & $2,808.7$ & $4,322.77$ & 1.54 & $4,322.77$ & 1.54 \\
\hline
\end{tabular}

${ }^{a}$ A decrease in withdrawals

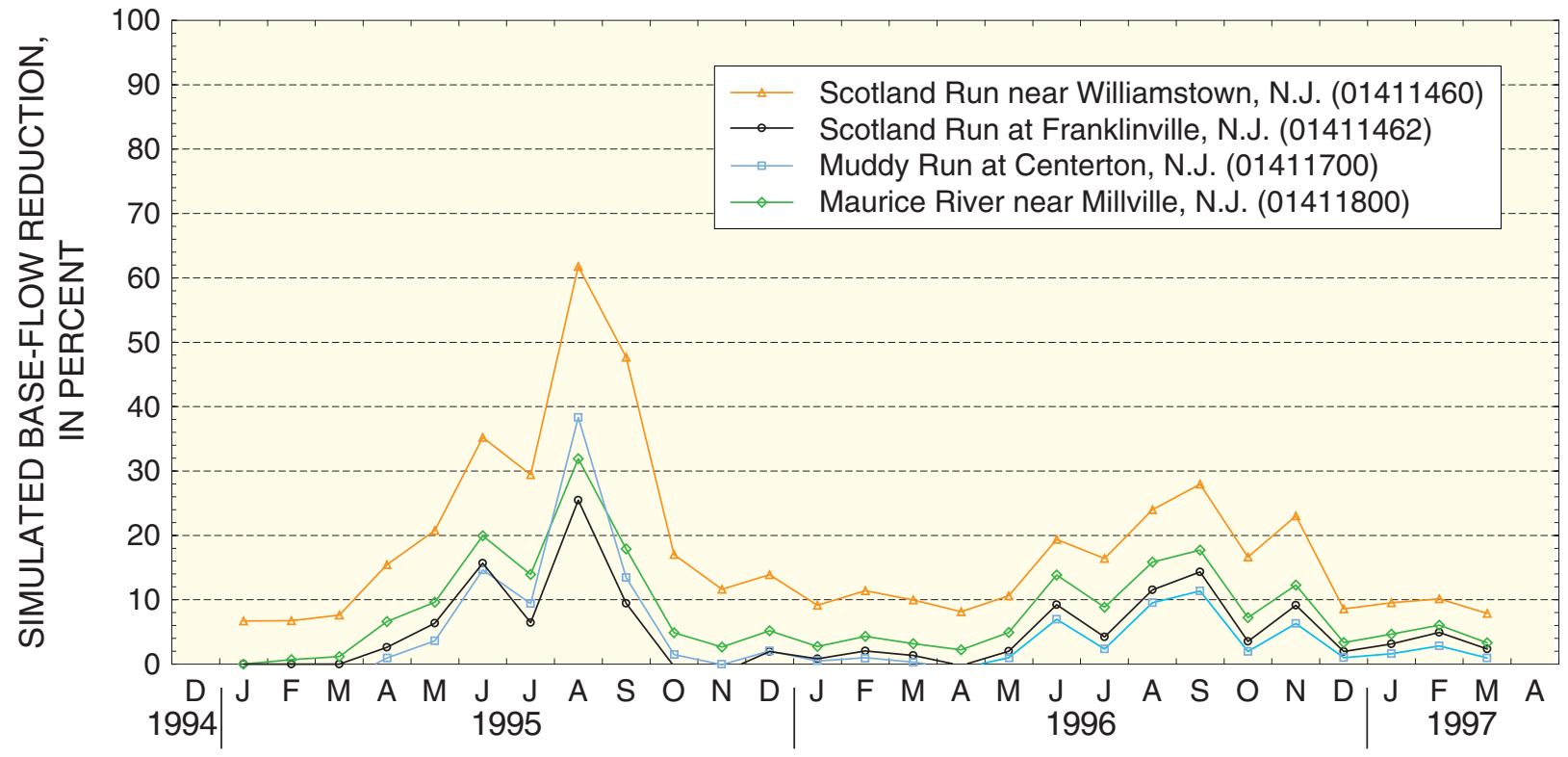

Figure 23. Simulated base-flow reduction in the upper Maurice River Basin area at streamflow-gaging stations Scotland Run near Williamstown, N.J. (01411460); Scotland Run at Franklinville, N.J. (01411462); Muddy Run at Centerton, N.J. (01411700); and Maurice River near Millville, N.J. (01411800) as a result of post-development ground-water withdrawals. 

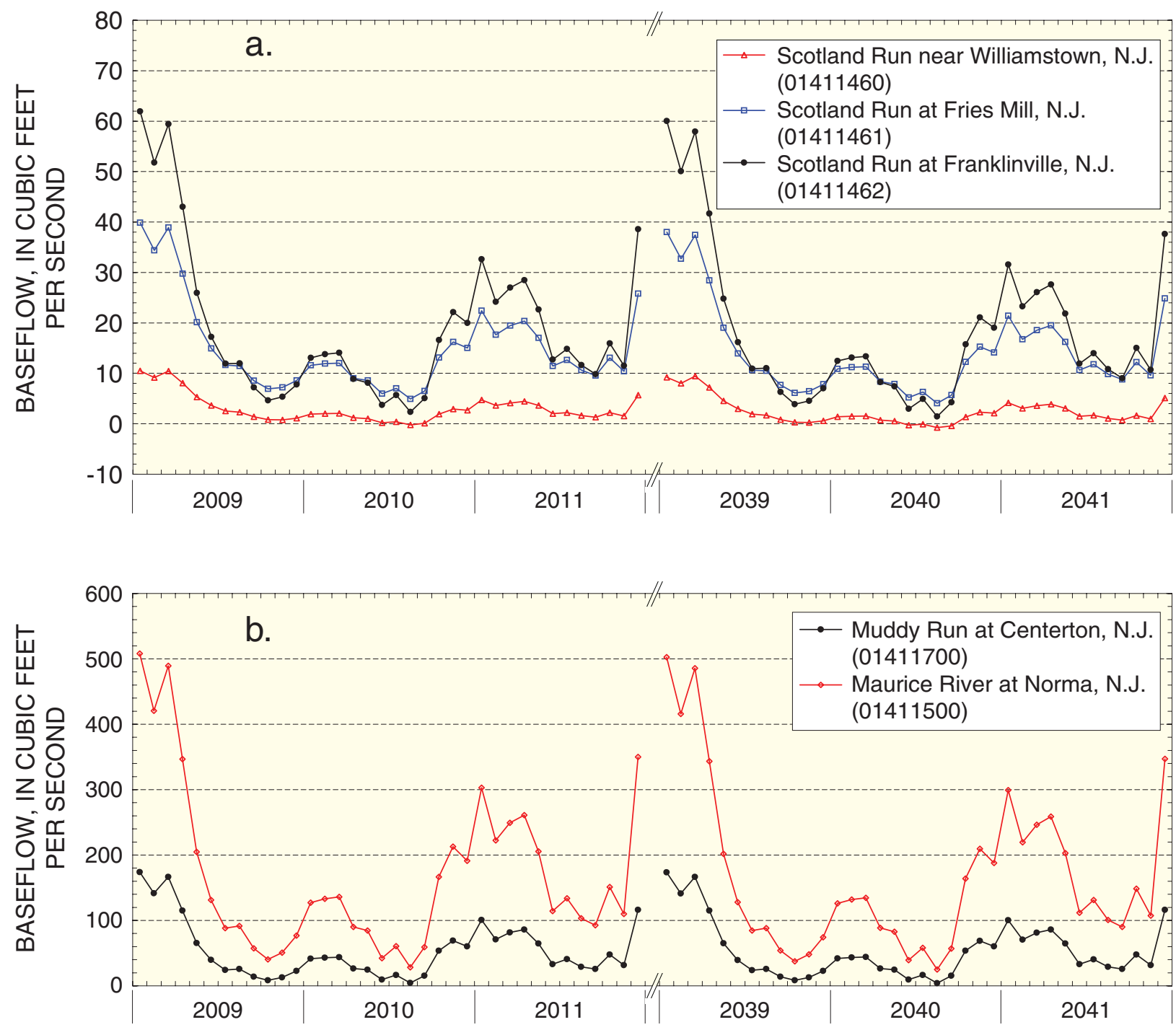

Figure 24. Simulated base flow at streamflow-gaging stations (a) Scotland Run near Williamstown, N.J. (01411460); Scotland Run at Fries Mill, N.J. (01411461); and Scotland Run at Franklinville, N.J. (01411462); and (b) Muddy Run at Centerton, N.J. (01411700); and Maurice River at Norma, N.J. (01411500), during 2009-11 and 2039-41, using estimated ground-water withdrawals.

greater during 2010 and 2011. The slope (fig. 24a) is typical of a large drainage area. Simulated base flow during August 2010 at Scotland Run at Fries Mill, N.J. (01411461), is $4.92 \mathrm{ft}^{3} / \mathrm{s}$ and $2.34 \mathrm{ft}^{3} / \mathrm{s}$ at Scotland Run at Franklinville, N.J. (01411462). Simulated base flow reaches yearly minima in September 2011 at Scotland Run at Fries Mill, N.J. (01411461), and Scotland Run at Franklinville, N.J. (01411462) $\left(9.56 \mathrm{ft}^{3} / \mathrm{s}\right.$ and $9.82 \mathrm{ft}^{3} / \mathrm{s}$, respectively). Although Scotland Run at Franklinville, N.J. (01411462), is farther downstream from, and has a larger drainage area than, Scotland Run at Fries Mill, N.J. (01411461), base flow is $1.3-2.5 \mathrm{ft}^{3} / \mathrm{s}$ less at 01411462 during the fall of 2009 and summer of 2010 because of the proximity of ground-water withdrawals. Responses to seasonal recharge and agricultural withdrawals are seen in monthly plots of base flow at Muddy Run at Centerton, N.J. (01411700) (fig. 24b).
Numerous agricultural wells are located in the Muddy Run Basin. Minimum monthly base flow simulated at Muddy Run at Centerton, N.J. (01411700), is $4.32 \mathrm{ft}^{3} / \mathrm{s}$ in August 2010 and $25.72 \mathrm{ft}^{3} / \mathrm{s}$ in September 2011. Base flow is greatest at Maurice River at Norma, N.J. (01411500), because of its drainage area of 112 square $\mathrm{mi}^{2}$. Simulations indicate that minimum monthly base flow at Maurice River at Norma, N.J. (01411500), occurs during August $2010\left(28.48 \mathrm{ft}^{3} / \mathrm{s}\right)$ and September 2011 (92.5 $\mathrm{ft}^{3} / \mathrm{s}$ ) (fig. 24b).

Simulation for the years 2039-41 yields nearly identical results as those of 2009-11 at each streamflow-gaging station. The demand projections for 2040 differ from those of 2010 by specified amounts of public-supply withdrawals (table 9). Water-use projections for industrial and agricultural uses are unchanged. Although the NJDEP forecast the amount of 
ground-water withdrawals (demands) at 5- and 10-year increments from 1995 through 2040 per community by projecting continuing development, they did not predict where new wells would be located within each community. The projected water demand simulation is based on the assumption that all increases occur at existing wells. Because of this, the effect of increased withdrawals from 2010 to 2040 occurs near the location of existing public-supply wells in the study area.

Because the major public-supply withdrawals are located in the upper (Scotland Run Basin) and lower (Vineland City) parts of the study area, it is instructive to assess 2040-41 simulated base flow at these locations. Simulations indicate that base flow ceases at Scotland Run near Williamstown, N.J. (01411460), becoming a losing reach from June through September 2040, and ranges from $0.78-1.66 \mathrm{ft}^{3} / \mathrm{s}$ during June through September 2041. Base flow is $4.08 \mathrm{ft}^{3} / \mathrm{s}$ at Scotland Run at Fries Mill, N.J. (01411461), and $1.46 \mathrm{ft}^{3} / \mathrm{s}$ at Scotland Run at Franklinville, N.J. (01411462), during August 2040 and 8.77 and $9 \mathrm{ft}^{3} / \mathrm{s}$, respectively, during September 2041. Minimum monthly base flow simulated at Maurice River at Norma, N.J. (01411500), is $25.14 \mathrm{ft}^{3} / \mathrm{s}$ during August 2040 and 89.91 $\mathrm{ft}^{3} / \mathrm{s}$ during September 2041 (fig. 24b.).

\section{Maximum allocation withdrawals}

A transient simulation of conditions that could occur during an extended drought illustrates the potential effect of all water users withdrawing ground-water at the maximum rate and quantity allowed by NJDEP water-allocation permits. All the wells with an allocation permit to withdraw ground water from the Kirkwood-Cohansey aquifer system in the study area as of 1997 were included in the simulation (fig. 25). Withdrawals from each well were set at a rate equivalent to their maximum allocation amount for each stress period of the simulation. The goal of this simulation was to compare base flow resulting from this condition to base flow during predevelopment and post-development simulated conditions.

When the NJDEP issues an allocation permit for a public-supply well (5,000 series) or a commercial/industrial well (2,000P series), a maximum monthly allocation and/or a maximum yearly allocation is designated for that well. Both of these values were used to estimate the monthly and annual withdrawals from all wells with an allocation permit in the study area. On some allocation permits, either a maximum yearly allocation or a maximum monthly allocation is specified. For public-supply wells, if only the maximum monthly allocation was provided, the maximum monthly allocation was multiplied by 8.2 to estimate the maximum yearly allocation. If only the maximum yearly allocation was available, the yearly allocation was divided by 8.2 to estimate a maximum monthly allocation. The multiplication/division factor of 8.2 was determined by comparing public-supply allocations at wells where both the maximum monthly and maximum yearly allocations had been established. Nearly all industrial and commercial wells (2000P series) had maximum monthly and yearly allocations designated when the permits were issued. In a few cases, the maximum monthly allocation was estimated by dividing the maximum yearly allocation by 12 or the maximum yearly allocation was estimated by multiplying the maximum monthly allocation by 12 . By definition, wells that have a $10,000 \mathrm{~W}$ series allocation permit number cannot withdraw more than 100,000 gallons per day or $3.1 \mathrm{Mgal} / \mathrm{mon}$ (million gallons per month). Maximum values for this series were set at 33 percent of the pump capacity or a maximum monthly allocation of $1.033 \mathrm{Mgal} / \mathrm{mon}$ and a maximum yearly allocation of $12.4 \mathrm{Mgal} / \mathrm{yr}$ (million gallons per year). Wells that have an agricultural certification generally are issued a maximum monthly allocation and a maximum yearly allocation that is 3.5 times the maximum monthly allocation. This is based on the assumption that agricultural wells will withdraw water at their maximum monthly allocation for half of May, and all of June, July, and August during a drought.

To estimate realistic monthly withdrawals, estimated values were increased gradually over the spring and summer months, and decreased over the fall and winter months for public-supply wells. This pattern is apparent in reported withdrawals and reflects increased water consumption during the summer. A weighting factor was applied to the monthly allocations at public-supply wells to simulate the seasonal increase and decrease in ground-water withdrawals. The weighting factor was based on reported monthly withdrawals during 1995. In all cases, the estimated monthly withdrawal did not exceed the maximum monthly allocation per well, and the total yearly allocation did not exceed the maximum yearly allocation per well.

Even though reported water use during 1994-97 did not approach the amounts allowed under maximum allocation conditions (table 10), maximum use conditions were simulated for those years to allow a direct comparison between the effect of ground-water withdrawals that have occurred and the effect of those that could occur. A transient simulation of maximum allocation conditions with monthly stress periods was performed using monthly recharge calculated for the period of 1994 through March 1997. Comparison of base flow during predevelopment conditions with base flow resulting from maximum allocation ground-water withdrawals indicates the magnitude of base-flow reduction that could occur during an extended drought. During a dry year like 1995, base flow would stop at Scotland Run near Williamstown, N.J. (01411460), from June through September (fig. 26a), and any flow in the stream would be lost to the aquifer. Base flow at Scotland Run at Franklinville, N.J. (01411462), also would stop during August under maximum allocation conditions (fig. 26c). Muddy Run at Centerton, N.J. (01411700), would convert to a losing reach during August 1995 if all agricultural wells were pumping at their maximum allocation values (fig. 27a). Other locations in the Maurice River Basin would experience considerable reduction in base flow due to the ground-water withdrawals simulated in this scenario (figs. $26 \mathrm{~b}, 27 \mathrm{~b}, 27 \mathrm{c}$ ). Reductions are calculated by comparing base flow for the same time period during maximum allocation 


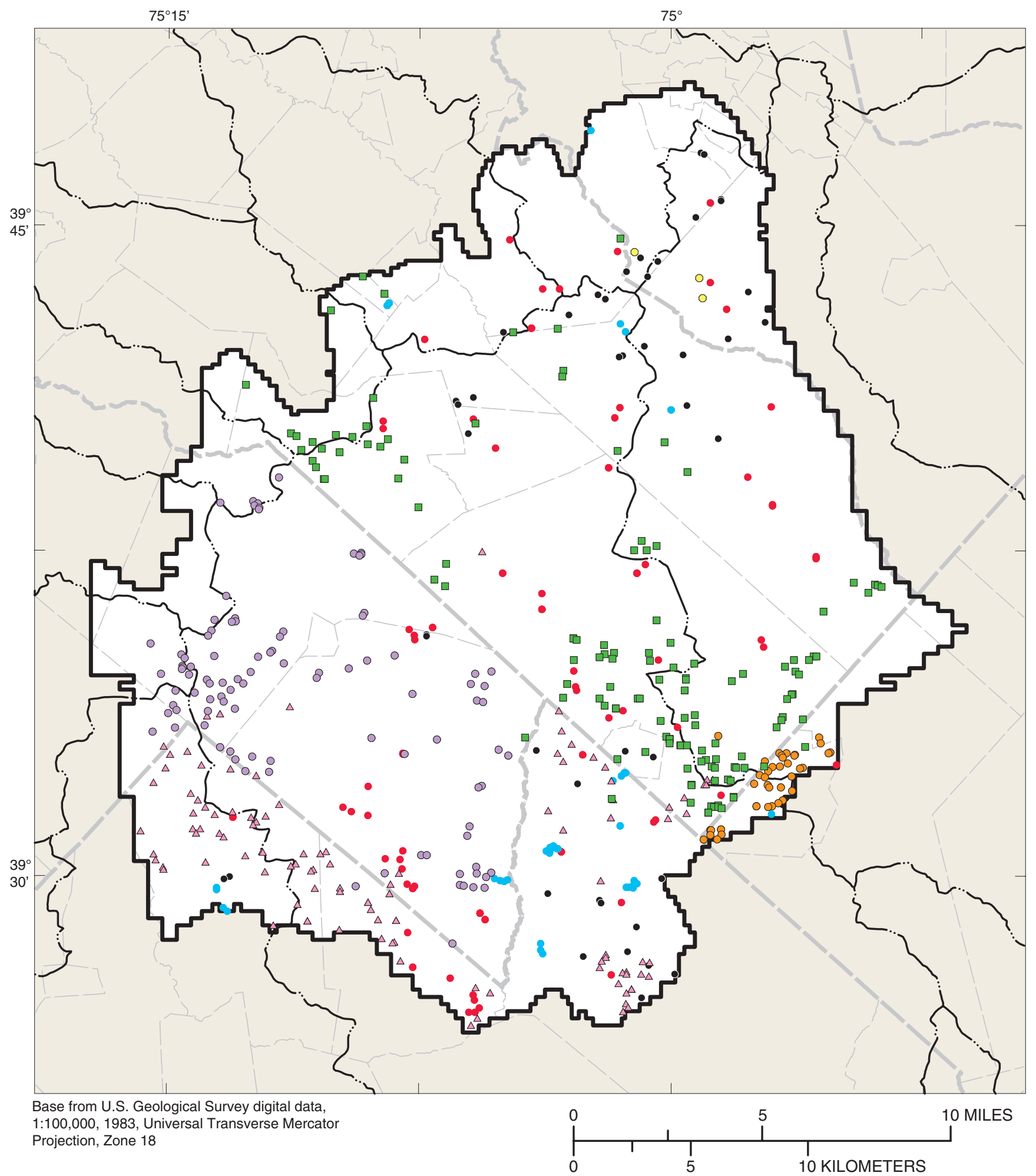

\section{EXPLANATION}
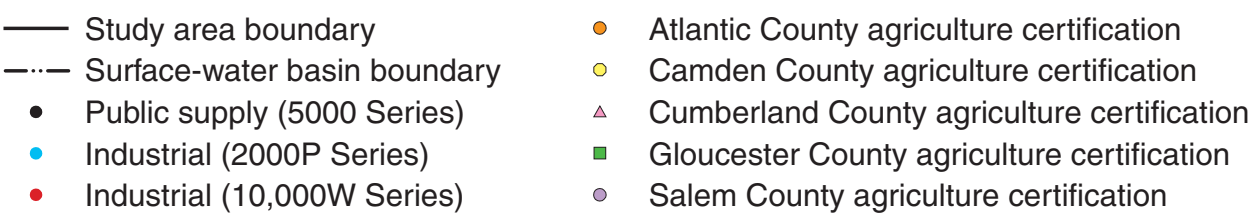

Figure 25. Location of all wells with a permitted ground-water withdrawal allocation from the Kirkwood-Cohansey aquifer system (as of 1997), in the upper Maurice River Basin area, N.J. 
Table 10. Reported and maximum allocation ground-water withdrawals, upper Maurice River Basin area, N.J., 1995.

[Small differences in totals are caused by independent rounding; Mgal/yr, million gallons per year]

\begin{tabular}{|c|c|c|c|}
\hline Water use (allocation permit series) & $\begin{array}{l}1995 \text { reported } \\
\text { withdrawals } \\
\text { (Mgal/yr) }\end{array}$ & $\begin{array}{c}\text { Maximum allocation } \\
\text { withdrawal } \\
\text { (Mgal/yr) }\end{array}$ & $\begin{array}{c}\text { Increase over } \\
1995 \text { reported } \\
\text { withdrawal (times) }\end{array}$ \\
\hline 2,000P (Industrial/Commercial) & $1,663.7^{1}$ & $3,804.03$ & 2.29 \\
\hline Agricultural Certifications & $2,808.7$ & $12,072.25$ & 4.3 \\
\hline Total & $9,951.06$ & $24,897.28$ & 2.5 \\
\hline
\end{tabular}

conditions (maximum withdrawal rates) to predevelopment conditions (prior to any ground-water withdrawal). Base flow would be 93.2 percent less under August 1995 maximum allocation conditions than under predevelopment conditions at Maurice River at Norma, N.J. (01411500) (fig. 28). Recharge was above average during 1996, yet simulation results indicate appreciable base-flow reductions. In particular, there would be 41.2 percent less base flow at Maurice River at Norma, N.J. (01411500), during September 1996.

The stress period representing maximum allocation conditions during August 1995 was evaluated to determine the effects of withdrawals during the peak of an extended drought on base flow. Simulated base flow during this stress period was compared to that of the same stress period (same recharge values) under predevelopment conditions when there were no withdrawals. The effects of withdrawals throughout the study area on stream cells are shown in figure 29. Stream cells where base flow decreased by greater than $0.5 \mathrm{ft}^{3} / \mathrm{s}$ and cells that converted from gaining to losing flow during August 1995 conditions are shown. Numerous stream cells in the headwaters of Scotland Run, Little Ease Run, and Still Run (fig. 29) were affected primarily by public-supply withdrawals. Many stream cells along Burnt Mill Branch and Hudson Branch in Newfield, Blackwater Branch in Buena Borough and Vineland City, and Pine Branch, Little Robin Branch, Tarnkill Branch, and Parvin Branch in Vineland City (fig. 3) were affected by the agricultural and public-supply withdrawals in this area. Muddy Run and its tributaries were affected at various points along its length as a result of the large number of agricultural withdrawals in this part of Salem County.

\section{Hydrologic boundaries and public-supply well location}

As land continues to be developed throughout this part of New Jersey and the demand for freshwater increases, water purveyors are deciding where to place new public-supply wells. Factors that affect well location usually relate to the proximity of the water-supply infrastructure (pipelines, connections, and water towers) and the availability of adequate ground water. An important consideration for installing a public-supply well is the effect that the withdrawals will have on the surface-water resources proximal to the well. Two wellplacement simulations were performed to examine the relation between ground-water withdrawals near selected hydrologic boundaries and the amount of ground water flowing into nearby streams.

To assess the effect that new public-supply wells could have on base flow in the upper Maurice River, three hypothetical wells were placed adjacent to the headwaters of Scotland Run in Monroe Township, Gloucester County (fig. 30). Simulated withdrawals at the three wells were based on reported withdrawals at three existing public-supply wells in Monroe Township. A transient simulation of conditions during 1994-97 with monthly stress periods was performed (simulation 1). This simulation included all reported withdrawals for this period in addition to the withdrawals at three hypothetical wells. A second simulation was performed (simulation 2) using alternative locations for the three hypothetical wells - on the surface-water divide between Scotland Run and Little Ease Run (fig. 30). Both simulations used the same hydrologic properties, duration, stresses, and initial conditions of the calibrated transient model. The only difference between the two simulations was the location of the three hypothetical wells. By comparing base flows at streamflow-gaging stations on both Scotland Run and Little Ease Run, it is possible to examine the effects of well placement near a discharge boundary (Scotland Run) or near a recharge boundary (inner-basin divide).

Base flow at Little Ease Run near Clayton, N.J. (01411456), Scotland Run near Williamstown, N.J. (01411460), and Maurice River at Norma, N.J. (01411500), was compared between the two simulations. The withdrawals from three hypothetical public-supply wells adjacent to Scotland Run caused a reduction in base flow during the entire 

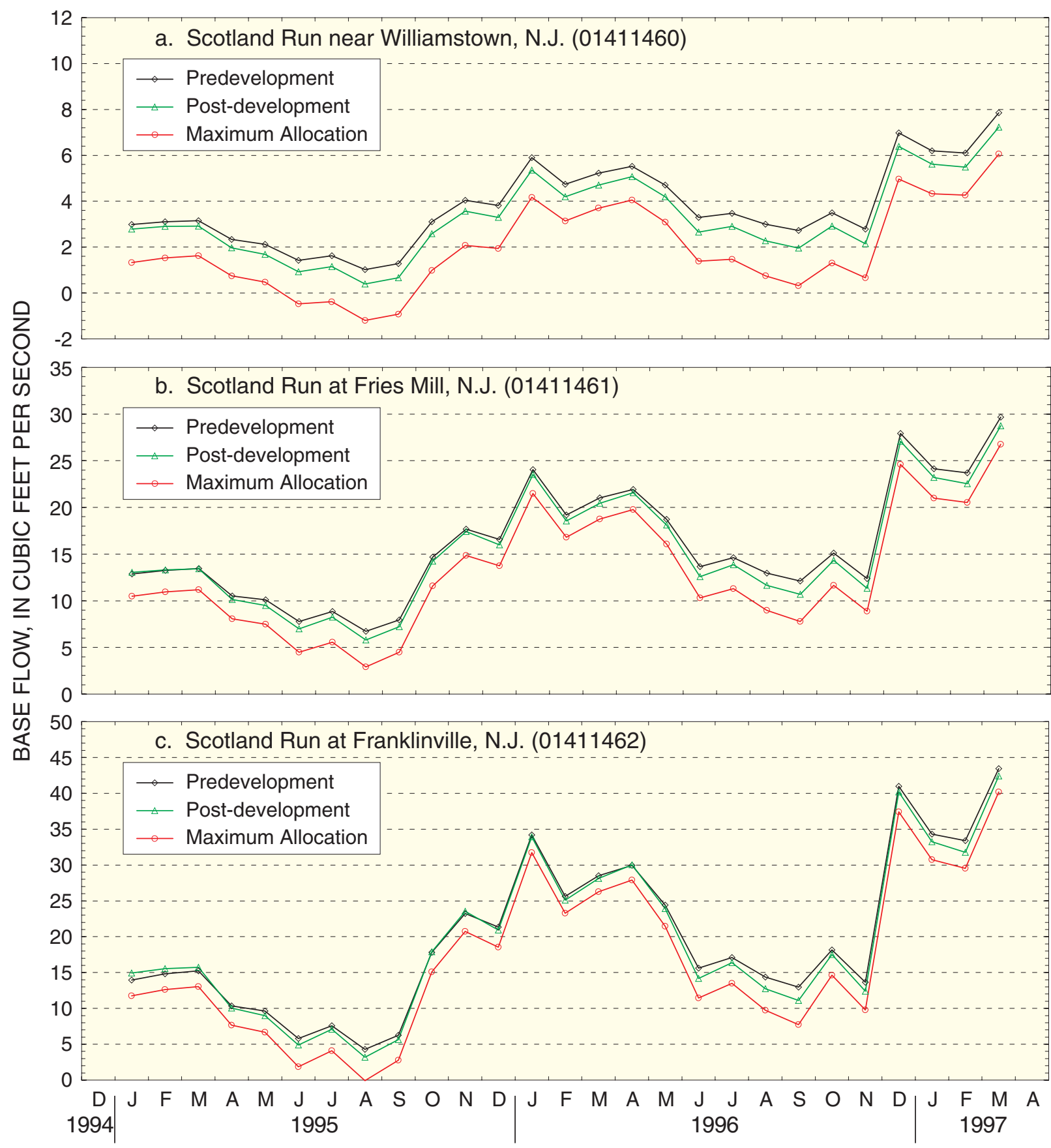

Figure 26. Simulated monthly base flow during predevelopment, post-development, and maximum allocation conditions at streamflowgaging stations (a) Scotland Run near Williamstown, N.J. (01411460); (b) Scotland Run at Fries Mill, N.J. (01411461); and (c) Scotland Run at Franklinville, N.J. (01411462).

simulation for January 1995 through March 1997 at Scotland Run near Williamstown, N.J. (01411460) (fig. 31a). The magnitude of the decrease is nearly the amount of water withdrawn from the three wells. When a combined total withdrawal rate of $2.03 \mathrm{ft}^{3} / \mathrm{s}$ was used during May 1995, base flow at Scotland Run near Williamstown, N.J. (01411460), was reduced by an additional $1.83 \mathrm{ft}^{3} / \mathrm{s}$ over post-development conditions. Base flow ceased during May through September 1995 when the wells were located adjacent to Scotland Run. When the three wells were located on the surface-water divide, base-flow reduction was less during May $1995-0.99 \mathrm{ft}^{3} / \mathrm{s}$ at Scotland Run near Williamstown, N.J. (01411460). Simulation of these conditions caused base flow to cease during June, August, and September 1995.

At Little Ease Run near Clayton, N.J. (01411456), baseflow reduction was $0.1 \mathrm{ft}^{3} / \mathrm{s}$ during May 1995 when the wells 


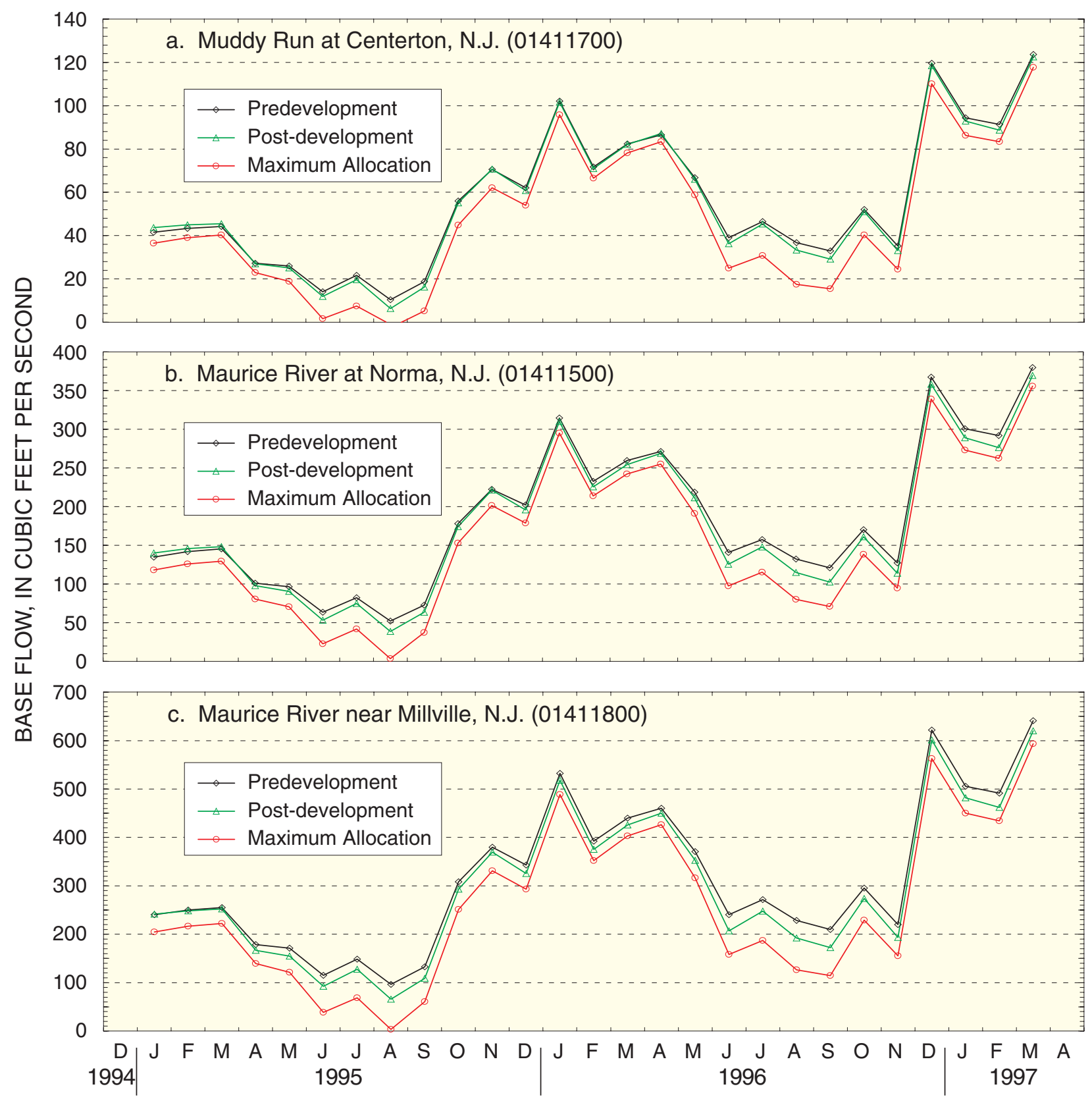

Figure 27. Simulated monthly base flow during predevelopment, post-development, and maximum allocation conditions at streamflowgaging stations (a) Muddy Run at Centerton, N.J. (01411700); (b) Maurice River at Norma, N.J. (01411500); and (c) Maurice River near Millville, N.J. (01411800).

were located adjacent to Scotland Run and $0.71 \mathrm{ft}^{3} / \mathrm{s}$ when the wells are on the surface-water divide (fig. 31b). During both simulations, base flow would cease at Little Ease Run near Clayton, N.J. (01411456), from June through September 1995. These simulations show that when the three public-supply wells were located in close proximity to the headwaters of Scotland Run, the ground water that normally flowed into Scotland Run (base flow) was diverted to the supply wells. Withdrawals from the public-supply wells have the potential to turn this segment of Scotland Run into a losing or dry reach during extended periods of little or no precipitation. The effect on Little Ease Run was minimal, with base-flow reduction no greater than $0.23 \mathrm{ft}^{3} / \mathrm{s}$ (December 1996) and usually much less. When the three public-supply wells were located on a recharge boundary, base-flow reduction in the headwaters of streams was distributed between subbasins. Base flow decreased in both Little Ease Run and Scotland Run from these conditions but the reduction in Scotland Run was considerably less $\left(0.09-1.02 \mathrm{ft}^{3} / \mathrm{s}\right)$. Ground water that would discharge into the 


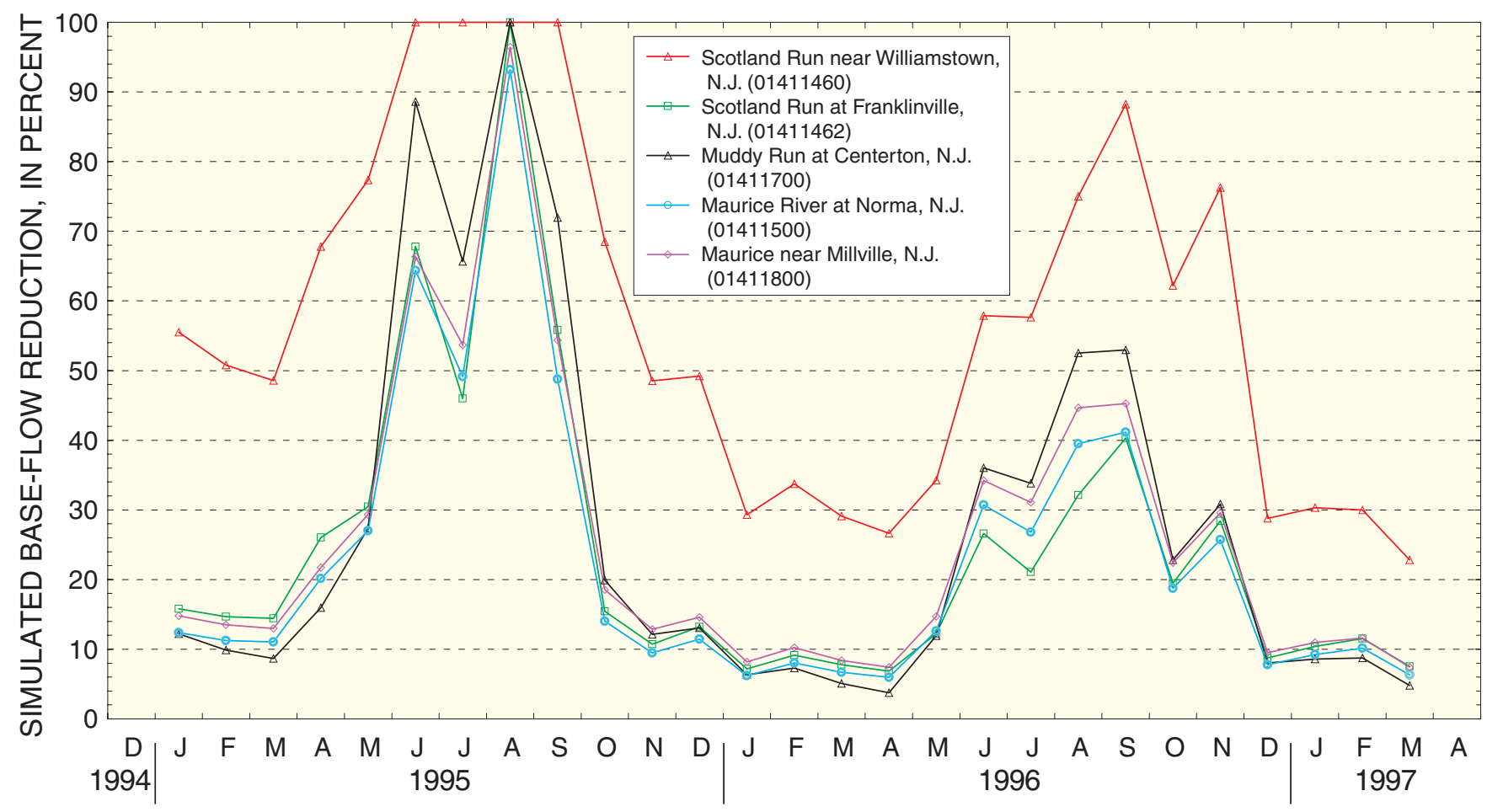

Figure 28. Simulated base-flow reduction in the upper Maurice River Basin area at streamflow-gaging stations Scotland Run near Williamstown, N.J. (01411460); Scotland Run at Franklinville, N.J. (01411462); Muddy Run at Centerton, N.J. (01411700); Maurice River at Norma, N.J. (01411500); and Maurice River near Millville, N.J. (01411800), due to maximum allocation ground-water withdrawals.

streams under non-stressed conditions was diverted to the supply wells.

At Maurice River at Norma, N.J. (01411500), the river had $1.92 \mathrm{ft}^{3} / \mathrm{s}$ less flow during May 1995 when the three wells were located adjacent to Scotland Run and $1.74 \mathrm{ft}^{3} / \mathrm{s}$ less flow when the wells were located on the surface-water divide. On the basis of the simulations, locating the wells several hundred feet within Monroe Township so that they are on the divide between Scotland and Little Ease Run rather than adjacent to Scotland Run would lessen the effect of ground-water withdrawals on flows in Scotland Run. 


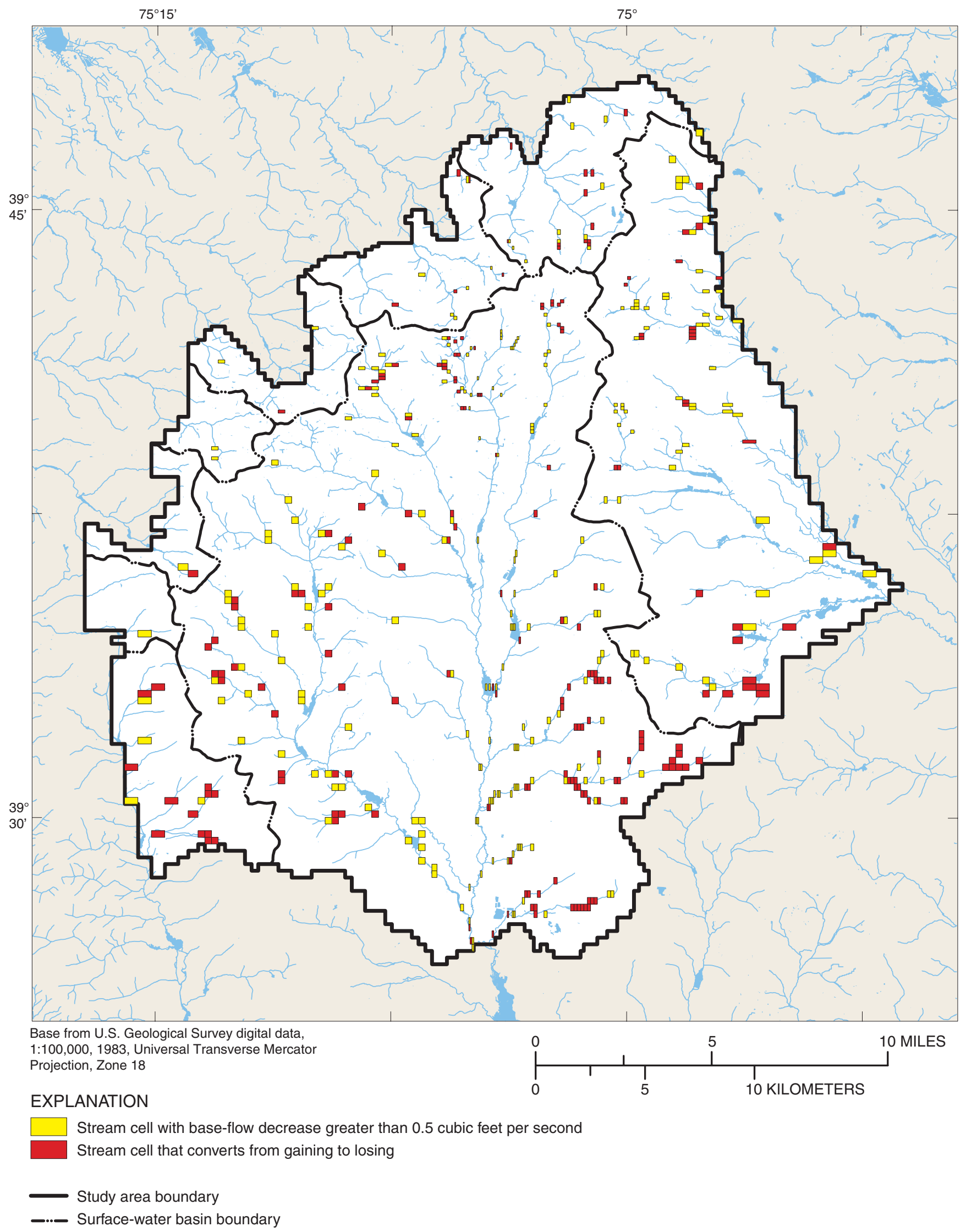

Figure 29. Location of stream cells with decrease of greater than 0.5 cubic feet per second in base flow or conversion from a gaining to losing cell resulting from maximum allocation ground-water withdrawals, in the upper Maurice River Basin area, N.J. 


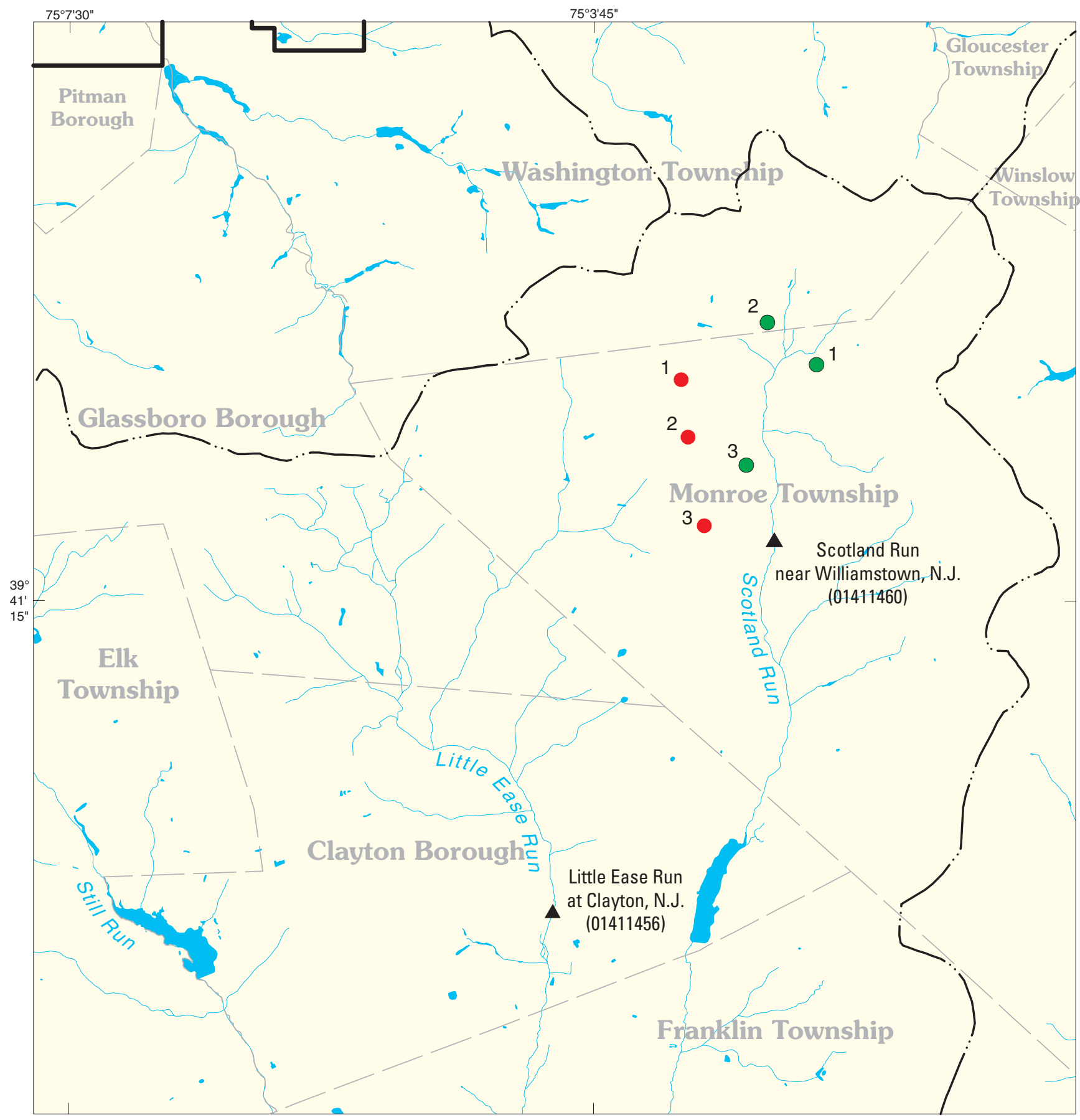

Base from U.S. Geological Survey digital data,

1:100,000, 1983, Universal Transverse Mercator

Projection, Zone 18

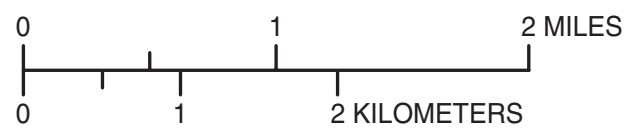

EXPLANATION

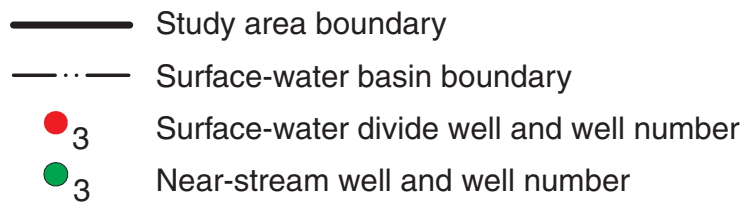

Figure 30. Location of three hypothetical public-supply wells in Monroe Township, Gloucester County located adjacent to Scotland Run (simulation 1), and on the surface-water divide between Little Ease Run and Scotland Run (simulation 2). 


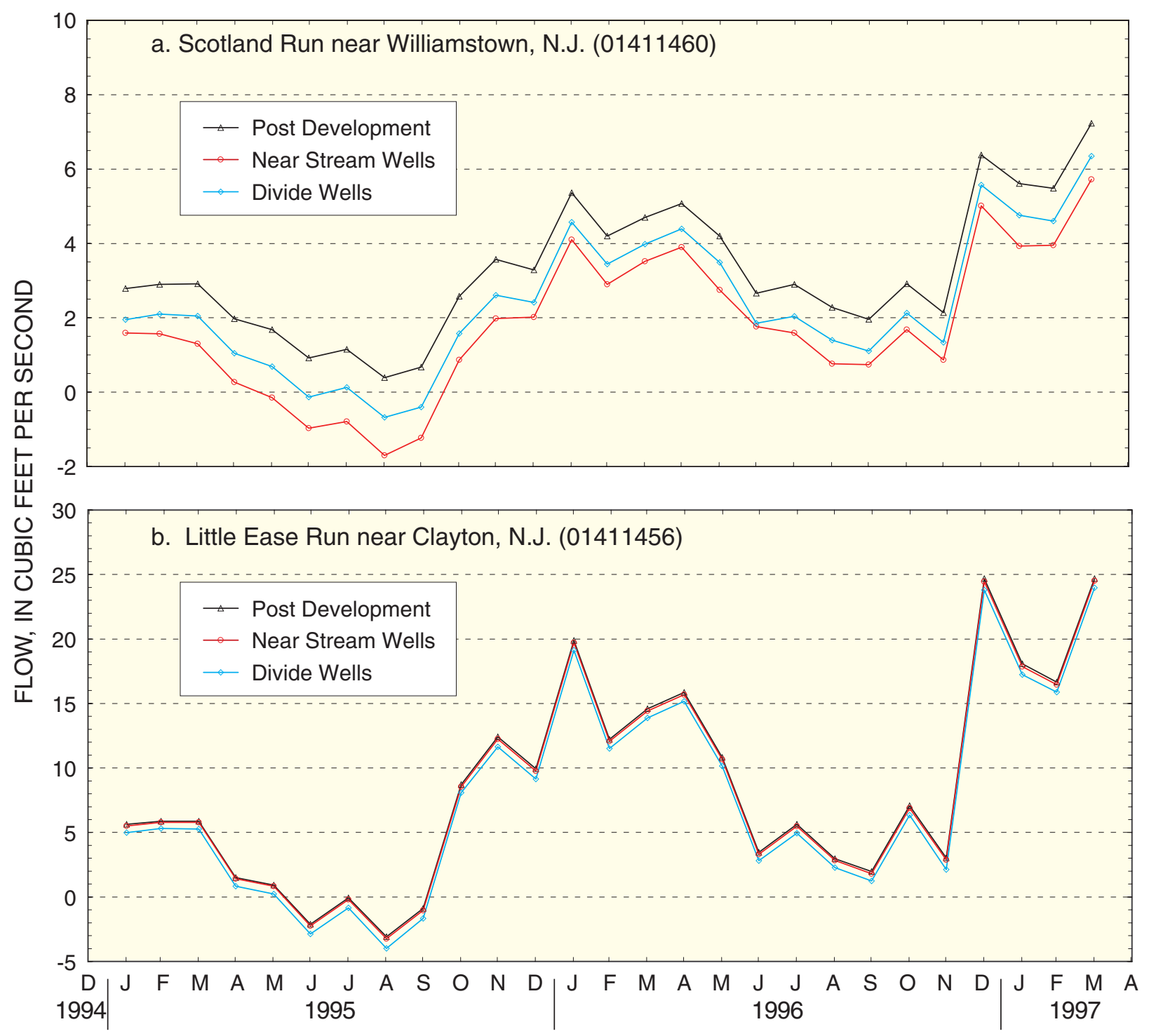

Figure 31. Simulated base flow at streamflow-gaging stations (a) Scotland Run near Williamstown, N.J. (01411460), and (b) Little Ease Run near Clayton, N.J. (01411456), using withdrawals from three hypothetical public-supply wells located near the stream or on a surface-water divide.

\section{Summary and Conclusions}

Ground water is withdrawn from the Kirkwood-Cohansey aquifer system in the study area of eastern Gloucester and Salem Counties, northern Cumberland, and western Atlantic Counties, New Jersey, to provide an adequate supply of freshwater for a variety of uses. Ground-water withdrawals for public supply occur primarily in the northern and south-central parts of the study area, whereas agricultural withdrawals occur primarily in the western and southern parts. Reported withdrawals from the Kirkwood-Cohansey aquifer system in this area during 1995 totaled 10 billion gallons. In this part of New Jersey, ground-water flow to streams, or base flow, is the major component of surface-water flow, especially during extended periods of little or no precipitation. Substantial ground-water withdrawals have the capacity to reduce base flow to the Maurice River, reducing the natural flow of the river, and decrease the size of wetland areas near or adjacent to the river. Because of increasing demand for freshwater in the study area, a study was conducted by the U.S. Geological Survey in cooperation with the New Jersey Department of Environmental Protection to determine the effect of current and projected ground-water withdrawals on ground-water flow in the unconfined Kirkwood-Cohansey aquifer system in the upper Maurice River Basin area.

The Kirkwood-Cohansey aquifer system is composed of the saturated parts of Holocene-age alluvial and colluvial deposits, the Miocene Bridgeton and Cohansey Formations, and the sandy portions of the Miocene Kirkwood Formation. The aquifer system is unconfined in the study area and is bounded by a basal clay unit of the Kirkwood Formation. 
A three-layer variably spaced model grid was used to discretize the study area. Model layers generally conform to hydrogeologic layers consisting of sand, silt, or clay. Model boundaries were established at no-flow hydrologic boundaries. A steady-state ground-water flow model was developed using average annual values of hydrologic properties and groundwater withdrawals. The model was calibrated to average conditions for 1990-95 by comparing simulated with estimated average annual base flow at 24 streamflow-gaging stations and simulated with measured ground-water altitudes at 46 observation wells for this time period.

The calibrated steady-state model was used to develop a transient ground-water flow model. Hydrologic properties of the steady-state model were modified during the transient calibration. Monthly values of recharge were derived using a modified water-budget methodology. Monthly recharge and ground-water withdrawals at all production wells from January 1994 through March 1997 were used in the development of the transient model. To calibrate the model, simulated and measured monthly ground-water altitudes and simulated and estimated monthly base flow were compared for January 1995 to March 1997. Results of sensitivity analysis indicate that water-level altitudes and base flow in the calibrated steadystate and transient ground-water flow models are most sensitive to increases in recharge. Water-level altitudes are most sensitive to decreases in horizontal hydraulic conductivity and base flow is most sensitive to decreases in recharge.

Three-dimensional models of the Kirkwood-Cohansey aquifer system were developed to simulate ground-water flow in the study area under predevelopment conditions, postdevelopment (1995-97) conditions, and future conditions based on anticipated ground-water-withdrawal alternatives. Transient simulations were conducted using projected water demand within each municipality during 2010-11 and 204041, maximum allocation withdrawals during 1995-97, additional withdrawals from three hypothetical public-supply wells adjacent to Scotland Run, and additional withdrawals from three hypothetical public-supply wells located on the surfacewater divide between Little Ease Run and Scotland Run. A transient ground-water flow model was used to quantify the reduction in base flow in the Maurice River resulting from these withdrawal alternatives.

A comparison of the results of transient predevelopment and post-development simulations indicated the amount of simulated base-flow reduction in the Maurice River due to recent (1995-97) ground-water withdrawals. Numerous public-supply wells are within or near the boundary of the upper Scotland Run drainage basin. Considerable reductions in simulated base flow in Scotland Run (nearly 62 percent, equivalent to $0.63 \mathrm{ft}^{3} / \mathrm{s}$ during August 1995 at Scotland Run near Williamstown, N.J. (01411460)) occurred from postdevelopment conditions. Agricultural withdrawals in the Muddy Run Basin affected simulated post-development base flow at Muddy Run at Centerton, N.J. (01411700), resulting in a reduction of 38 percent $\left(3.97 \mathrm{ft}^{3} / \mathrm{s}\right)$ during August 1995. Simulated base flow farther downstream in the Maurice River at Norma, N.J. (01411500), decreased by nearly 26 percent $\left(13.47 \mathrm{ft}^{3} / \mathrm{s}\right)$ during August 1995. Total base flow at the same streamflow-gaging stations on the Maurice River during September 1996 was higher than during August 1995 as a result of higher recharge rates during 1996; nevertheless, the quantity of simulated base-flow reduction from pre- to post-development conditions was comparable or higher. Simulated base flow was reduced by $0.76 \mathrm{ft}^{3} / \mathrm{s}$ at Scotland Run near Williamstown, N.J. (01411460); $3.74 \mathrm{ft}^{3} / \mathrm{s}$ at Muddy Run at Centerton, N.J. (01411700); and $18.39 \mathrm{ft}^{3} / \mathrm{s}$ at Maurice River at Norma, N.J. (01411500), during September 1996.

Ground-water demand projections for the years 1995 , 2000, 2005, 2010, 2020, 2030, and 2040 were used to simulate the effects of anticipated ground-water withdrawals for the years 2010-11 and 2040-41. This simulation used 1995 recharge rates (below average) for the years 2010 and 2040, and 1996 rates (above average) during 2011 and 2041. Results indicate that during the August 2010 simulation, base flow stopped at Scotland Run near Williamstown, N.J. (01411460), and declined to $4.92 \mathrm{ft}^{3} / \mathrm{s}$ at Scotland Run at Fries Mill, N.J. (01411461), and $2.34 \mathrm{ft}^{3} / \mathrm{s}$ at Scotland Run at Franklinville, N.J. (01411462). Seasonal recharge and agricultural groundwater withdrawals affected base flow at Muddy Run at Centerton, N.J. (01411700). Simulated minimum monthly base flow decreased to $4.32 \mathrm{ft}^{3} / \mathrm{s}$ at this station and $28.48 \mathrm{ft}^{3} / \mathrm{s}$ at Maurice River at Norma, N.J. (01411500), during the August 2010 simulation. Results for the 2040 simulation were similar. Base flow at Scotland Run near Williamstown, N.J. (01411460), ceased from June through September 2040. Simulated base flow was $4.08 \mathrm{ft}^{3} / \mathrm{s}$ at Scotland Run at Fries Mill, N.J. (01411461); $1.46 \mathrm{ft}^{3} / \mathrm{s}$ at Scotland Run at Franklinville, N.J. (01411462); and $25.14 \mathrm{ft}^{3} / \mathrm{s}$ at Maurice River at Norma, N.J. (01411500), during August 2040. Because higher recharge rates were used for the 2011 and 2041 simulations, monthly base flow at Maurice River at Norma, N.J. (01411500), reached yearly lows of $92.5 \mathrm{ft}^{3} / \mathrm{s}$ in September 2011 and 89.91 $\mathrm{ft}^{3} / \mathrm{s}$ in September 2041.

Simulation of maximum-allocation ground-water withdrawal conditions demonstrated the magnitude of base-flow reduction that could occur during a protracted drought. The Maurice River experienced considerable reductions in base flow due to the conditions simulated in this scenario, particularly during periods of low recharge. Simulation of climatic conditions during 1994-97 indicated that during a dry year like 1995, base flow would stop at Scotland Run near Williamstown, N.J. (01411460), from June through September. Base flow at Scotland Run at Franklinville, N.J. (01411462), and at Muddy Run at Centerton, N.J. (01411700), would have stopped during August 1995. A comparison of maximum-allocation conditions with predevelopment conditions indicated base flow was reduced by 93 percent during August 1995 at Maurice River at Norma, N.J. (01411500). Although recharge was greater than average during 1996, simulation results indicated there would have been a 41-percent reduction in base flow at this site in September 1996 under maximum-allocation conditions. 
Results of simulations using additional ground-water withdrawals from three hypothetical public-supply wells indicated that siting the wells in the upper part of the Maurice River Basin affected the magnitude of base-flow reduction in the headwaters of Scotland Run and Little Ease Run. A nearly one-to-one correspondence was observed between the amount of water withdrawn from the Kirkwood-Cohansey aquifer system and the decrease in base flow to Scotland Run when using high-volume withdrawals near or adjacent to the stream. When withdrawal wells were located on surface-water divides between adjacent headwater tributaries (Scotland Run and Little Ease Run), however, the amount of water withdrawn from the wells was distributed between the subbasins, reducing the effects on, and increasing the quantity of base flow to, Scotland Run.

\section{Acknowledgments}

The authors gratefully acknowledge the assistance of Donald Storck and Nicholas Smith of the USGS in the collection and analysis of data for this project. Scott Tyrrell of the New Jersey Department of Environmental Protection provided many helpful suggestions in addition to well-permit, waterallocation-permit, and water-use data in support of this study.

\section{Literature Cited}

Anderson, M.P., and Woessner, W.W., 1991, Applied Groundwater Modeling: Simulation of Flow and Advective Transport: San Diego, California, Academic Press, Inc., 381 p.

Barksdale, H.C., Greenman, D.W., Lang, S.M., Hilton, G.S., and Outlaw, D.E., 1958, Ground-water resources in the tri-state region adjacent to the lower Delaware River: New Jersey Department of Conservation and Economic Development Special Report 13, 190 p.

Cauller, S.J., Carleton, G.B., and Storck, M.L., 1999, Hydrogeology of, water withdrawal from, and water levels and chloride concentrations in the major Coastal Plain aquifers of Gloucester and Salem Counties, New Jersey: U.S. Geological Survey Water-Resources Investigations Report 98-4136, 123 p., 6 pls.

Charles, E.G., Storck, D.A., and Clawges, R.M., 2001, Hydrology of the unconfined aquifer system, Maurice River area: Maurice and Cohansey Rivers, New Jersey, 1994-95: U.S. Geological Survey Water-Resources Investigations Report 01-4229, 5 sheets.

Forstall, R.L., 1995, Population of counties by decennial census: 1900 to 1990: U.S. Bureau of the Census, accessed November 20, 2001, at http://www.census.gov/population/ cencounts/nj190090.txt
Harbaugh, A.W., Banta, E.R., Hill, M.C., and McDonald, M.G., 2000, MODFLOW-2000, The U.S. Geological Survey modular ground-water model - user guide to modularization concepts and the ground-water flow process: U.S. Geological Survey Open-File Report 00-92, 121 p.

Hardt, W.F., and Hilton, G.S., 1969, Water resources and geology of Gloucester County, New Jersey: New Jersey Department of Conservation and Economic Development Special Report 30, 130 p.

Isphording, W.C., 1970, Petrology, stratigraphy, and re-definition of the Kirkwood Formation (Miocene) of New Jersey: Journal of Sedimentary Petrology, v. 40, no. 3, p. 986-997.

Johnson, M.L., and Charles, E.G., 1997, Hydrology of the unconfined aquifer system, Salem River area: Salem River and Raccoon, Oldmans, Alloway, and Stow Creek Basins, New Jersey, 1993-94: U.S. Geological Survey WaterResources Investigations Report 96-4195, 5 sheets.

Kummel, H.B., and Knapp, G.N., 1904, The stratigraphy of the New Jersey clays, in Ries, Heinrich, Kummel, H.B., and Knapp, G.N., The clays and clay industry of New Jersey: New Jersey Geological Survey, v. 6, pt. 2, p. 117-208.

Lacombe, P.J., and Rosman, R., 1995, Hydrology of the unconfined aquifer system in the upper Maurice River Basin and adjacent areas in Gloucester County, New Jersey, 198687: U.S. Geological Survey Water-Resources Investigations Report 92-4128, 5 sheets.

McDonald, M.G., and Harbaugh, A.W., 1988, A modular three-dimensional finite-difference ground-water flow model: U.S. Geological Survey Techniques of WaterResources Investigations, book 6: modeling techniques, chapter A1, 576 p.

Newell, W.L., Powars, D.S., Owens, J.P., Stanford, S.D., and Stone, B.D., 2000, Surficial geologic map of central and southern New Jersey: U.S. Geological Survey Miscellaneous Investigations Series Map I-2450-D, 21 p., 3 sheets.

New Jersey Department of Environmental Protection, 1996, Water for the 21st century: The vital resource-New Jersey statewide water supply plan: Trenton, N.J., New Jersey Department of Environmental Protection, August 1996, $173 \mathrm{p}$.

Nicholson, R.S., and Watt, M.K., 1997, Simulation of groundwater flow in the unconfined aquifer system of the Toms River, Metedeconk River, and Kettle Creek Basins, New Jersey: U.S. Geological Survey Water-Resources Investigations Report 97-4066, 100 p. 
Owens, J.P., and Minard, J.P., 1979, Upper Cenozoic sediments of the lower Delaware Valley and the northern Delmarva Peninsula, New Jersey, Pennsylvania, Delaware, and Maryland: U.S. Geological Survey Professional Paper 1067-D, 47 p.

Owens, J.P., Sugarman, P.J., Sohl, N.F., Parker, R.A., Houghton, H.F., Volkert, R.A., Drake, A.A., Jr., and Orndorff, R.C., 1998, Bedrock geologic map of central and southern New Jersey: U.S. Geological Survey Miscellaneous Investigations Series Map I-2540-B, 4 sheets.

Rhodehamel, E.C., 1973, Geology and water resources of the Wharton Tract and the Mullica River Basin in southern New Jersey: New Jersey Department of Environmental Protection Special Report 36, 58 p.

Rooney, J.G., 1971, Ground-water resources, Cumberland County, New Jersey: New Jersey Department of Environmental Protection Special Report 34, 83 p.

Rosenau, J.C., Lang, S.M., Hilton, G.S., and Rooney, J.G., 1969, Geology and ground-water resources of Salem County, New Jersey: New Jersey Department of Conservation and Economic Development Special Report 33, 142 p.

Rutledge, A.T., 1993, Computer programs for describing the recession of ground-water discharge and for estimating mean ground-water recharge and discharge from streamflow records: U.S. Geological Survey Water-Resources Investigations Report 93-4121, 45 p.

U.S. Bureau of the Census, 2001, U.S. Census Bureau: State and County Quickfacts, U.S. Bureau of the Census, accessed November 20, 2001, at http://quickfacts.census. gov/qfd

Watt, M.K., and Johnson, M.L., 1992, Water resources of the unconfined aquifer system of the Great Egg Harbor River Basin, New Jersey, 1989-90: U.S. Geological Survey WaterResources Investigations Report 91-4126, 5 sheets.

Zapecza, O.S., 1989, Hydrogeologic framework of the New Jersey Coastal Plain: U.S. Geological Survey Professional Paper 1404-B, 49 p., 24 pls. 